Universidade de Brasília

Instituto de Letras

Departamento de Teoria Literária e Literaturas

Programa de Pós-graduação em Literatura

\title{
A MENINA NEGRA DIANTE DO ESPELHO
}

\author{
Dalva Martins de Almeida
}

Orientadora: Cintia Carla Moreira Schwantes

Brasília - DF 
Dalva Martins de Almeida

\section{A MENINA NEGRA DIANTE DO ESPELHO}

Dissertação apresentada ao Programa de Pós-Graduação em Literatura do Departamento de Teoria Literária e Literaturas - TEL do Instituto de Letras da Universidade de Brasília - UnB como requisito parcial para a obtenção do título de Mestre. Área de concentração: Literatura

Linha de Pesquisa: Representação Literária

Orientadora: Prof ${ }^{\mathrm{a}}$. Dr ${ }^{\mathrm{a}}$. Cintia Carla Moreira Schwantes

Brasília - DF 


\title{
A MENINA NEGRA DIANTE DO ESPELHO
}

\author{
Banca Examinadora
}

Prof ${ }^{a}$. Dr ${ }^{\mathrm{a}}$ Cintia Carla Moreira Schwantes - TEL/UnB (Orientadora e Presidente da Banca)

Prof ${ }^{\mathrm{a}}$. Dr ${ }^{\mathrm{a}}$ Gislene $\mathrm{M}^{\mathrm{a}}$ Barral L. F. da Silva - TEL/ UnB

(Membro externo)

Prof. Dr. Anderson Luís Nunes da Mata - TEL/UnB

(Membro interno)

Virgínia Maria Vasconcelos Leal- TEL/UnB

(Membro suplente) 


\section{Agradecimentos}

Passarinho me contou ${ }^{1}$ que a ciranda ou roda é uma das brincadeiras mais antigas. Eles falaram também que, quando os portugueses desembarcaram nas terras brasileiras, brincavam fazendo uma grande roda, com gestos e cantos. E falou o Passarinho que os índios brasileiros também brincavam em roda, mas acharam divertidas aquelas cantigas dos portugueses. Mas Passarinho não se lembra de ter visto indíos e portugueses na mesma ciranda. Passarinho só se lembra o quanto era muito bom cirandar e cantar: "Oh, cirandeiro, cirandeiro ó, a pedra do seu anel brilha mais do que o sol". 2

Para que a ciranda funcione, são necessárias muitas pessoas dispostas a seguir, de mãos dadas, um ritmo. A brincadeira só será divertida se todos forem juntos seguindo os passos, os gestos e o canto. Então, quero agradecer a todos que seguraram firmes as minhas mãos e juntos dançaram essa ciranda comigo. Em primeiro lugar, aos meus pais: Carlos e Celcina (Dezinha) meus tutores naturais. Os que me fizeram ser o que sou. A parte melhor de mim. Aos meus irmãos (Quintino, Maria Iris, Francisco, Sueli, Naná, Amanda) e familiares, que foram tão indulgentes durante minhas crises dissertativas.

Aos trovadores: Anderson Luís Nunes da Mata, Regina Dalcastagnè, Virgínia Leal, Cristina Stevens, Sara Almarza, Ana Claudia Silva, Edvaldo Bergamo, Maria Isabel Edom Pires, Piero Eyben, Sylvia Cintrão, Elizabeth Hazin... Que souberam marcar o ritmo para manter a ciranda viva.

Ao pessoal da secretaria do TEL, em especial, à Marcilene, por seu poder de acolhimento. Aos cirandeiros: Bete Barros, Kelly, Rosa Alda, Geise, Cris, Clara, Lemuel, Lorena, Douglas, Rosilene, Camila, Luciana, Ana Clara, Pedro, David, ao GELBC, ao TEL (aos que não couberam nesta página, mas estão na ciranda).

À Mônica, Liliane, Consuêlha, Ivone, Cláudia, Carla, Adriana Levino, Lúcia Helena... (a ciranda só cresce). Todos os meus amigos (que são muitos), em especial, à Cida Cruz menina-mulher guerreira, em quem eu me espelho e quem canta, alegremente na ciranda.

E à Cíntia Schwantes (ou Carla Moreira) a minha eterna tutora que, simultaneamente, orienta, apoia, ri e chora junto. Aquela que, fadamente, me indica caminhos. Quem me segura às mãos com firmeza na ciranda.

Aos que, do espaço sideral, me inspiram a continuar nos volteios da roda da vida.

\footnotetext{
${ }^{1}$ Expressão popular. Tradição oral. Grifos meus.

${ }^{2}$ Cantiga de roda. Tradição oral brasileira.
} 


\section{RESUMO}

Esta pesquisa tem como objetivo refletir sobre as múltiplas formas de representação da menina negra, pela análise comparativa das obras da literatura infantil contemporânea: $O$ Espelho Dourado (2003) e Histórias da Preta (2005) de Heloísa Pires Lima; Betina (2009), de Nilma Lino Gomes; e As Tranças de Bintou (2005), de Sylviane A. Diouf. Através da observação de recortes de discursos e imagens que atravessam esses textos, intenta-se evidenciar o engendramento da protagonista menina-negra e a revelação da mesma como sujeito da pós-modernidade, constituído após desconstrução de processos de invisibilização, proferidos pelo discurso do mito da democracia racial ou o racismo à brasileira. Para tal, é preciso debruçar-se sobre as contribuições dos Estudos Culturais, bem como os estudos de gênero, classe social e etnia.

Palavras-chave: Literatura Infantil. Estudos Culturais. Visibilidade. Representação. 


\begin{abstract}
This research aims to reflect about the multiple forms of representation of the black girl through the analysis of works of contemporary literature: O Espelho Dourado (2003) and Histórias da Preta (2005) by Heloísa Pires Lima; Betina (2009), by Nilma Lino Gomes; e As tranças de Bintou (2005), by Sylviane A. Diouf. Through the interpretation of parts of discourses and images which pervade these texts, it is aimed to evidence the engendering of the protagonist black girl and its revelation as a subject of post modernity, built over the deconstruction of a process of invisibility, contained in the myth of racial democracy, or Brazilian racism. In order to accomplish it, it is required to take into account the Cultural Studies as well as the Gender Studies, and class and ethnicity.
\end{abstract}

Keywords: Children’s Literature. Cultural Studies. Visibility. Representation. 


\section{Sumário}

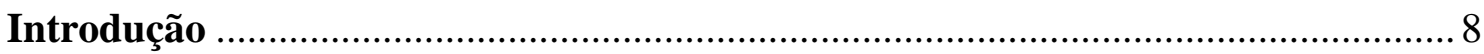

Literatura infantil e infância: nascimentos cruzados ............................................ 11

1. 1 Dos "Despropósitos": a busca por reter a água ................................................... 12

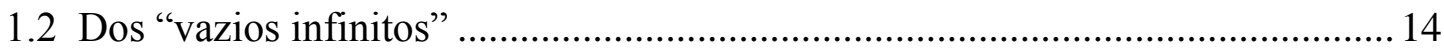

1.3 Das fontes medievais da literatura popular infantil............................................ 19

1.4 A consolidação da literatura infantil .............................................................. 22

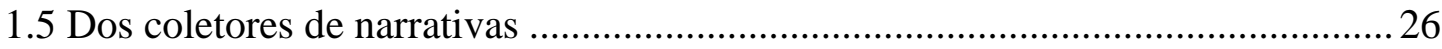

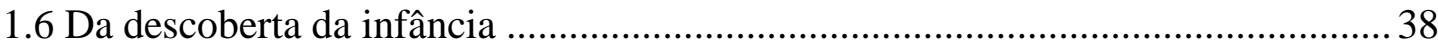

Da criação lobatiana às perspectivas contemporâneas da literatura infantil brasileira

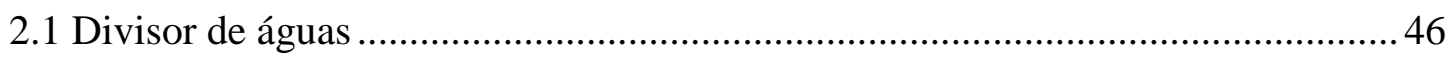

2.2 O segundo divisor das águas: a década de 1960 ................................................. 48

2.3 Década de 1970 e 1980: o boom na literatura infantil brasileira...........................49

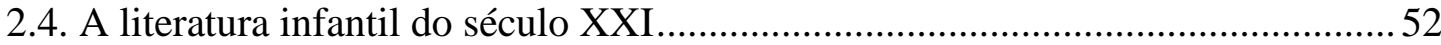

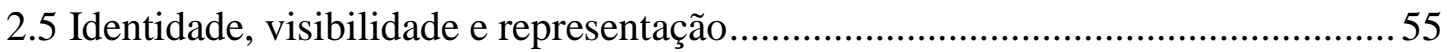

2.6 Espaços de agenciamento da identidade de gênero da menina negra ....................60

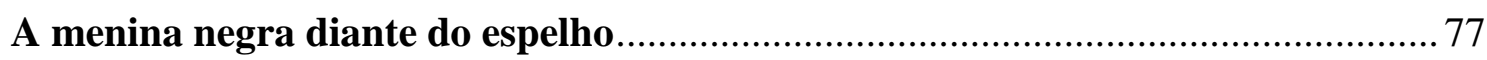

3.1 A escrevivência das negras mãos ...................................................................... 78

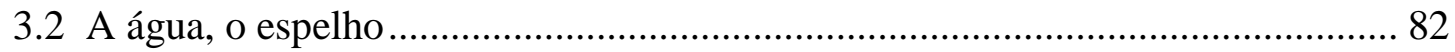

3.3 Betina: uma narrativa de formação ………........................................................... 90

3.4 Meninas negras diante dos “espelhos sociais" ................................................... 100

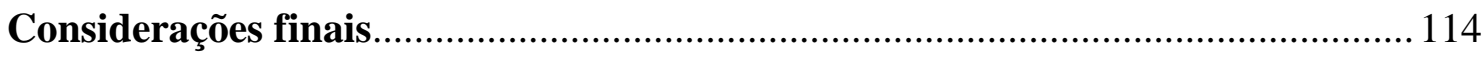

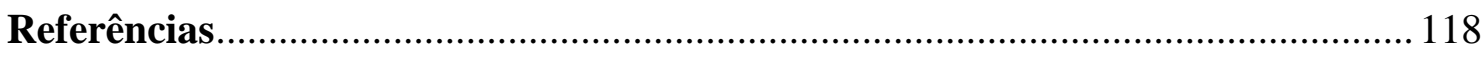

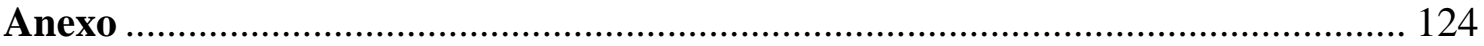




\section{Introdução}

Ao estudar o gênero literatura infantil na contemporaneidade, é preciso concordar com Regina Zilberman (2003) que, entre suas explanações, discute sobre a vastidão de possibilidades de estudo e de trabalho, e observar o quanto este campo artístico vem se ramificando. Essas possibilidades de ampliação do gênero incluem o redimensionamento de ação da literatura infantil de espaço, meramente didático, para campo artístico.

Deste modo, ao ampliar-se como campo artístico, a literatura infantil contemporânea pode se tornar um importante instrumento de emancipação e de revisão de esquemas reprodutores de estereótipos, presentes na sociedade brasileira e reproduzida nas instâncias sociais, tais como: família, grupos sociais, escola.

Esta postura renovada da literatura infantil na contemporaneidade favorece a desconstrução do mito da democracia racial praticado no Brasil. E isso inclui a prática do rompimento com a minimização das relações de discriminação e da pouca visibilidade da pessoa negra nas imagens veiculadas pelos diversos suportes e meios de comunicação de massa.

A infância é o espaço da vida humana onde a estrutura de violência contabiliza seus maiores casos. Se há um grupo preferencialmente tributário dessa violência, este grupo é o da menina negra. É nesse grupo social que os processos de violência e preconceito aprofundam suas raízes. Ao longo de um extenso período, a literatura infantil foi um dos meios por onde desfilaram as características inferiorizantes relacionadas às meninas negras.

A relação de estereótipos se estende ao $\operatorname{corpo}^{2}$, ao cabelo e à personalidade da menina negra. À menina negra são imputados os adjetivos de feia, má, preguiçosa, imoral, selvagem, passiva. Ou ainda, o mascaramento desses mesmos termos: "negra com alma branca", "preta, porém, limpinha", "trabalhadeira", "beleza exótica”, “moreninha” (grifos meus). Esses posicionamentos perante a menina negra não dissolvem a relação desigual que as mesmas vivenciam na sociedade brasileira. Ao contrário, reproduzem o status quo do mito da democracia racial à brasileira.

Essas posturas são os espelhos nos quais a menina negra brasileira tem se mirado. No entanto, o que ela vê não é a sua própria imagem. Essas imagens sociais a representam ou representam as marcas de um passado de escravidão? Como a literatura infantil contemporânea pode reverter a ideologia do branqueamento? Quais são os espaços para a

\footnotetext{
${ }^{2}$ Durante o texto tratarei o corpo e o cabelo como categorias para evidenciar a questão da
} construção da identidade da menina negra como sujeito. 
construção de uma literatura infantil afroidentificada ${ }^{3}$. Assim, a proposta desta pesquisa está centrada em como a menina negra é representada na literatura infantil contemporânea. A análise será baseada em quatro obras de escritoras afrodescendentes: $O$ Espelho Dourado e Histórias da Preta, de Heloísa Pires Lima; Betina, de Nilma Lino Gomes, e As tranças de Bintou, de Sylviane A. Diouf. As duas primeiras escritoras são afro-brasileiras e a última é francesa, descendente de senegaleses.

Para o encadeamento das discussões, este texto foi dividido em três capítulos. O primeiro é intitulado "Literatura infantil e infância: nascimentos cruzados". Nesse capítulo realizo um levantamento da gênese da literatura infantil como gênero, situando-a desde a tradição oral aos grandes clássicos, com o propósito de demonstrar a trajetória desse fenômeno literário e a ampliação de suas possibilidades enquanto campo de produção artística. Meu intuito é redimensionar a definição do que é a literatura infantil, o rompimento efetuado nesse âmbito na atualidade, e ampliar o seu campo de ação. ${ }^{4} \mathrm{~A}$ importante questão do surgimento da infância cruzado ao surgimento da literatura infantil como gênero revela que esses dois eventos não nasceram isolados e é de onde parte a discussão sobre a função da literatura infantil como objeto pedagógico.

Por sua vez, o segundo capítulo, "Da criação lobatiana às perspectivas contemporâneas da literatura infantil brasileira", percorro a constituição da literatura nacional. No entanto, a ênfase é dada à produção da literatura infantil na contemporaneidade. A escolha pela literatura infantil após o boom verificado nas décadas de 1970 e 1980 propõe que em cada época, a literatura infantil encabeçou uma discussão política. Então, ao traçar cada divisor de águas, observa-se que a literatura infantil brasileira, de período em período, renovou-se e foi também um palco de resistência.

No entanto, ao atingir o século XXI, coube à literatura infantil se reinventar para comportar discussões políticas, culturais, sociais, históricas, filosóficas e outras posturas solicitadas pela sociedade contemporânea. Nesse bojo, insere-se a discussão de como desconstruir o imaginário corrente na sociedade brasileira, sobre o corpo negro. Precisamente, o corpo da menina negra. Daí a importância de se discutir a construção da identidade da menina negra pelo rompimento dos processos de racismo, através da representação e da visibilidade como medidas emergenciais.

\footnotetext{
${ }^{3}$ Termo usado por Eduardo de Assis Duarte em seu texto Literatura Afro-Brasileira, 2014.

4 A literatura infanto-juvenil, exatamente pelo lugar quase marginal que ocupa dentro do cânone, tem as possibilidades de exploração de temas usualmente ignorados ampliadas. Ademais, o patrocínio estatal, na figura dos programas de constituição de bibliotecas escolares (a exemplo do PNBE) obrigam a contemplação de obras que promovam a inclusão. (Grifos meus)
} 
O terceiro capítulo ou "A menina negra diante do espelho" é a parte do texto em que visito os textos literários para sorver-lhes as imagens, verbais ou pictóricas, que demonstram como a menina negra é representada. Assim como, até que ponto essa representação pode ser significativa para o público que a consome. Ou seja, se as imagens representadas são promotoras de diálogo com a menina negra, se elas a espelham.

A questão do pertencimento da pessoa negra também é discutida no terceiro capítulo. E, embora tenha incluído uma escritora não brasileira, a discussão sobre a presença ou tendência de uma escrita negra de literatura infantil afroidentificada não se esvazia ou pulveriza. As obras e suas artífices são importantes escolhas políticas para o entendimento de como representar a menina negra na literatura e como essa representação redimensiona o corpo infantil da menina negra, através da visibilidade do cabelo como portador de simbologia e tradição cultural. Destarte, a análise parte da construção literária das protagonistas: Nyame, Betina, Bintou e Preta. Ademais, as aventuras de Bintou também são acessíveis para as crianças brasileiras, em tradução.

Ao olhar as protagonistas em conjunto ou separadamente, é possível perceber que os aspectos estéticos do gênero são evidenciados; no entanto, como caminho metodológico, parti dos estudos dos teóricos históricos da literatura infantil, que vão desde Leonardo Arroyo e Câmara Cascudo a Nelly Novaes Coelho, bem como de estudos medievalistas de Aeurbach e Roger Chartier. Em relação à infância, destacam-se os estudos de Ariès, Stearns e Mary Del Priori. Para a ampliação do que vem a ser a literatura infantil contemporânea foi necessário debruçar-me sobre Regina Zilberman, Peter Hunt, Ana Maria Machado, entre outros. Como essa análise não poderia acontecer sem o olhar multidisciplinar dos Estudos Culturais, foi preciso passear por várias vertentes. Nesse aspecto, caminhei junto aos estudos de Mignolo, Bourdieu, Stuart Hall, Michael de Certeau, Hannah Pitkin, Iris Young. Além de Eduardo Assis Duarte, Kabemguelê Munanga, entre outros.

Isso implica dizer que para a compreensão de como se dá a visibilidade positiva da menina negra na sociedade contemporânea, os caminhos são complexos e se requer uma atitude não solitária. É requerida a conjugação de várias forças da sociedade. Urge a assunção de um olhar descentrado e multicultural. E, para este olhar, vos convido. 
Literatura infantil e infância: nascimentos cruzados 


\section{1 Dos "Despropósitos": a busca por reter a água}

Com o tempo aquele menino que era cismado e esquisito

Porque gostava de carregar água na peneira

Com o tempo descobriu que escrever seria o mesmo que carregar água na peneira. A mãe falou: meu filho, você vai ser poeta. Você vai carregar água na peneira a vida toda.

E algumas pessoas vão te amar por seus despropósitos

(O menino que carregava água na peneira. Manuel de Barros, 2013, p. 453-

454).

A aventura insólita do menino de Barros (2013), de encher a peneira com água, pode ser compreendida, por um lado, como um ato insano pelo leitor desatento. No entanto, por um olhar mais acurado, tal ação se redimensiona, afinal, "transportar água na peneira" é imagem plena de significados. Uma maneira de ler essa imagem é relacioná-la ao trabalho dos estudiosos da literatura infantil que intentam lhe dar uma definição. Deste modo, o que é literatura infantil constitui-se, na contemporaneidade, mais que uma questão, é uma atitude interdisciplinar dos críticos que lutam por ressignificá-la com o intuito de revelar-lhe, entre outras características, as múltiplas faces deste fenômeno literário.

Não importa se o menino quer, de fato, reter a água, por saber que isto é improvável, mas sim o resultado da experiência em transportar a água com a peneira, através da observação dos detalhes que incluem a fluidez da água ao escorrer pelos espaços da peneira, sua efêmera permanência e o seu retorno para o volume maior. Ao menino é a constância, é a permanência e a ausência do líquido que o impulsionam a continuar na tarefa de encher espaços vazios.

De alguma maneira, esta imagem provoca a motivação ao pensar a profundidade da literatura infantil enquanto campo literário, bem como a dificuldade dos estudiosos em delimitar tais origens para compreender seus avanços e constituir uma definição.

Em que sentido definir literatura infantil transforma-se em paradoxo ou em um despropósito? Para que estudar literatura infantil? Estas questões não possuem uma única resposta. As maneiras de definir a literatura infantil estão relacionadas e controladas por seu propósito. A definição de literatura infantil também atrela-se à tensão entre a "aceitação intelectual da pluralidade de sentidos da palavra "literatura" e o suposto “conceito cristalizado de valores absolutos" (HUNT, 2010, p.75). 
Decorre das palavras de Hunt (2010) que o ponto tensional ou os nós que precisam ser desmanchados para a definição de literatura infantil, dizem respeito ao julgamento da mesma em seu valor estético e ao público a que se destina. Nesta questão do público está englobada uma ampla discordância que aponta para a possibilidade de se abordar a literatura infantil do mesmo modo que se aborda a literatura para adultos. E assim, cabe aí a questão de como tais literaturas, infantil e adulta, diferem e em que ponto elas confluem.

A historiografia da literatura infantil aponta para duas características: sua efemeridade e sua eternidade. Estas categorias encerram espaço profundo e não completamente preenchido, e podem dar pistas de como conceituar a literatura infantil. A efemeridade, para Hunt (2010, p. 27), é reflexo das discussões em torno do seu valor cultural. Esta questão torna a literatura infantil algo homogêneo e essa postura pode subestimá-la em sua diversidade e vitalidade. Desse modo, definir literatura infantil é um complexo processo. E isto está expresso na análise de vários estudiosos desse campo.

A título de exemplo, para Leonardo Arroyo (2010) a literatura infantil é um campo de produção cultural e histórica que comporta olhares diferenciados: ora no sentido estrito, como gênero destacado da literatura geral, numa conceituação técnica, num sentido vulgar e comum, ora em um olhar amplo, quando se designa uma realidade vasta, num processo de evolução lenta, que engloba a compreensão dessa matéria através do esmiuçar das remotas origens das expressões culturais (ARROYO, 2010, p. 26).

Nas palavras do prefaciador da primeira edição de Literatura infantil brasileira (2010), Lourenço Filho, Arroyo percorre o caminho de conotação mais ampla da literatura infantil, com o intuito de esclarecer a associação entre esta e o conceito da transmissão geral da cultura, para extrair-lhe a caracterização evolutiva pressuposta, ou seja, o exame da tradição oral em povos antigos de onde emergiram temas que sobrevivem ao tempo, e a importante transposição da oralidade para a escrita, observada em países da Europa e no Oriente. Essa busca implica na existência de um inconsciente coletivo e envolve a tradição oral.

E, mesmo assim, esses elementos, isoladamente, não definem literatura infantil. Arroyo (2010, p. 26) adverte sobre essa "deficiência" na conceituação, relacionando-a ao momento em que a forma escrita se desenvolveu e os padrões foram sendo selecionados por idade, ou seja, adaptados aos níveis de desenvolvimento. Isto aponta, para Arroyo (2010), a influência do didatismo em face da diluição do valor estético da obra literária. Contudo, tais proposições não esgotam esta questão, que será retomada em outro momento do texto. 
Desta forma, a conceituação de literatura infantil na acepção de Arroyo (2010, p.28), ou seja, a "expressão da cultura de um povo" é um campo que se renova. E, alinhavando esta constatação com as ideias de outros estudiosos como Zilbermann (2003), que afirma ser a literatura infantil "um extenso e desconhecido campo de trabalho", cujo perfil ainda está por ser definido (ZILBERMANN, 2003, p. 11), é possível compreender que a literatura infantil é uma parte da cultura que não se pode ignorar. Talvez, a resposta sobre a profundidade específica a esse campo literário, como na água peneirada, encontre pistas na tradição oral e popular da qual se serviu para formação.

\subsection{Dos "vazios infinitos"}

\footnotetext{
“A mãe reparou que o menino gostava mais do vazio do que do cheio. Falava que os vazios são maiores e até infinitos." (O menino que carregava água na peneira. Manuel de Barros, 2013, p. 453-454).
}

É envolvente, como constata o eu lírico nos versos de Barros (2013), a opção do menino pelos "vazios" mais do que pelo "cheio". Vistos conjuntamente, os vazios e os cheios formam um todo. E essa característica, relacionada à vastidão de possibilidades, talvez não facilite a conceituação da literatura infantil. No entanto, ela revela seu aspecto multifacetado e plural. A partir das falas autorais citadas, surge uma variante primordial para se conceituar a literatura infantil, que é a sua função no processo de formação da consciência cultural desenvolvida integralmente na caminhada humana. É imperioso visitar esses espaços cheios e, significantemente, vazios.

Uma perspectiva inicial é o rastreamento da gênese e evolução da literatura infantil, que para Coelho (2010), está baseada em dados histórico-culturais influenciadores da tal criação literária. Destarte, enquanto categoria, tal aspecto históricocultural atribui importância ao passado oral ou às tradições herdadas. Em sua visão, a autora avalia que este "passado" é o chão por onde se deve seguir a caminhada rumo ao presente, com subsídios para a construção do futuro. Onde principia esse chão? Esticar os passos e retomar o passado oral, alcançar o período "clássico" ou da Novelística Popular Medieval, denominada como célula-máter, e aprofundar nas raízes ancestrais mais remotas das fontes indo-orientais, é um percurso provável (COELHO, 2010, p.11). 
A caminhada em direção aos primórdios recondiciona o que se discute sobre os clássicos da literatura infantil, pois é comum voltar-se o olhar apenas para La Fontaine, Perrault, os Grimm e, claro, para Andersen. No entanto, constata-se nos estudos multidisciplinares, citados por Coelho, que a demarcação do surgimento da Literatura Infantil desloca-se para outras épocas, e revela que os verdadeiros autores das narrativas recolhidas pertencem a espaços e tempos diferenciados e longínquos.

Por sua vez, os caminhos seguidos pela literatura popular seguem imbricados. Essa literatura pode ser compreendida por suas fontes orais e impressas, e envolve os provérbios, adivinhações, contos, frases-feitas, orações, cantos. A característica principal da literatura popular, conforme Cascudo (2006) é "a sua persistência pela oralidade". Ao caráter popular aproxima-se também o folclórico. E, para o autor, “o folclórico é popular mas nem toda literatura popular é folclore”. Assim, para compreensão do folclórico, ele apresenta quatro características importantes: antiguidade, persistência, anonimato e oralidade (CASCUDO, 2006, p. 22). Ele explica:

\begin{abstract}
Uma produção, canto, dança, anedota, conto, que possa ser localizado no tempo, será um documento literário, um índice de atividade intelectual. Para que seja folclórica é preciso uma certa indecisão cronológica, um espaço que dificulte a fixação no tempo. Pode dizer-se a época, uma época extensa, mas não a restringindo mesmo à indicação de uma década. Natural é que uma produção que se popularizou seja folclórica quando se torne anônima, antiga, resistindo ao esquecimento e sempre citada, num ou noutro meio denunciador da predileção ambiental. O folclórico decorre da memória coletiva, indistinta e contínua (CASCUDO, 2006, p. 22-23).
\end{abstract}

O trabalho desses estudiosos, ao esmiuçar tais origens, é baseado em hipóteses observadas a partir das categorias variantes/invariantes recolhidas de documentos encontrados em várias regiões. Esses documentos estavam registrados em diversos materiais: inscrições em pedras, em tábuas de argila ou de vegetal, escrituras em papiro ou pergaminho, entre outros, e permitiram o nosso conhecimento quanto ao que foi dito há milênios e perpetuado ao longo do tempo.

O oral não é tão simples de ser explicado. Na oralidade, a leitura dos escribas egípcios de cerca de 1300 a.C. era entendida como declamação, ler denotava falar. Para que todo o lido, falado e declamado fosse perpetuado, havia a presença de uma figura especial, necessária como testemunha imortal, que seria a guardiã e depositária das informações. "Assim nasce a escrita, transformando a palavra humana em pedra" (FISCHER, 2006, p. 9).

A palavra transmuta-se no elemento revelador do ambiente hostil dos homens primitivos, que vencem os reveses da natureza através da força advinda de seus rituais. 
Esse caráter mágico e fantasioso é próprio da literatura primordial, preservada pela memória dos povos, e é a base das narrativas orientais, forjadas durante séculos que precederam a era cristã e atravessaram o tempo pela "Tradição Oral". Isso foi possível pela capacidade comunicativa do homem, através da contação de histórias (COELHO, 2010, p. 8).

A literatura popular floresce das narrativas primordiais, repleta de toda linguagem do mito, das lendas. Precisamente, as narrativas primordiais orientais forjam as narrativas medievais arcaicas populares e folclóricas europeias. Esse processo de constituição assemelha-se a uma rede impulsionadora da vida universal. No encadeamento desse extenso caminho do acervo narrativo inaugural da literatura popular, surge o ciclo narrativo Calila e Dimna, possivelmente de origem indiana.

Este ciclo, Calila e Dimna, é um fabulário ou um tratado político que ensinava os princípios da boa convivência. Por sua vez, no fabulário de Esopo, a estrutura narrativa constituía-se por estórias breves, ao passo que em Calila e Dimna, a estrutura narrativa era caracterizada por um encadeamento de estórias, a chamada caixa de estórias, que continha como fio condutor de cada grupo de narrativas, o rei indiano Dahshalim, que costumava pedir histórias ao príncipe dos filósofos, Baidaba.

Assim como Coelho (2010), Arroyo (2003) faz referências ao ciclo narrativo Calila e Dimna, e observa que nos estudos dos orientalistas se aponta como período de divulgação desse ciclo o século V a.C. e de sua divulgação, por tradução persa, o século VI d. C. Há controvérsia quanto à antiguidade deste ciclo em relação aos papiros egípcios encontrados anteriormente. No entanto, outro aspecto considerado diz respeito à perenidade de Calila e Dimna, que, entre outras, é uma coletânea considerada pelos orientalistas como pertencente ao texto sagrado de Pantcha-Tantra, livro de lendas, apólogos e estórias usados por pregadores budistas (ARROYO, 2003, p. 17).

Curiosamente, Arroyo ressalva a presença de aspectos pedagógicos na literatura infantil em texto sagrado, o que a evidencia como instrumento de educação. Esses textos ultrapassaram tradição oral e chegaram às versões dos copistas. Outro livro também é citado pelo autor, o Hitopadexa, que, traduzido, significa instrução saudável, que colheu larga popularidade por sua beleza e por incorporar uma novidade, o gênero "apólogo".

Através das traduções, as narrativas de As Mil e Uma Noites surgem, tardiamente, na Europa, como pertencentes ao fabulário de Calila e Dimna. Isso se dá através do enviado do rei que sai em busca de sabedoria e encontra Pilpay ou Bidpay ou o Esopo oriental, isso na metade do século VI da era cristã. Esse fato é relatado por monges que 
perambulavam na Pérsia e a Índia. São célebres versões compiladas dos contos orientais, cuja forma atual foi completada no fim do século XV.

Coelho (2010) aponta a inserção de elementos alheios aos costumes mulçumanos, tais como: elementos fantásticos indianos, gentilismo, magia e demonologia persa. Como consequência das traduções e adaptações, são presentes nas narrativas ocidentais: violência, poder dos fortes em relação aos fracos, a luta por poder, a astúcia como estratégia dos fracos, a representação das ações humanas por animais e as narrativas edificantes. Ou seja, os valores, os padrões e a literatura da Antiguidade Oriental são mesclados aos da cultura ocidental.

Como precisar o surgimento das primeiras manifestações literárias ocidentais? A esse respeito, salienta Arroyo (2003):

\begin{abstract}
A rica fantasia oriental espraiou-se por toda a Europa, um "rio verdadeiramente caudaloso", na expressão de Menéndez y Pelayo, que fluiu em traduções do árabe para o hebreu, do hebreu para o latim, do latim para as línguas vulgares. É o caso lembrado por Renato Almeida desse Calila e Dimna, que se desdobrou no Roman du renart(Romanceiro de Renart), na Disputa del asno (Disputa do asno), de Frei Anselmo Turmeda, em Boccaccio, nos Fabliaux, no Conde de Lucanor, de Juan Manuel, nos contos e provérbios da Disciplina Clericalis, na compilação de Pedro Alfonso, em La Fontaine. O mesmo fenômeno se observou com o livro Sandelbar, traduzido do árabe para o castelhano (ARROYO, 2003, p. 18).
\end{abstract}

Coelho (2010) utiliza a mesma trajetória citada por Arroyo para justificar a constituição das manifestações culturais ocidentais, sobre a importância das origens folclórica e popular das narrativas. Ou seja, o folclórico e o popular são as fontes derivadas da prosa narrativa "exemplar" de ordem oriental ou greco-romana. A fonte tida como culta advém da prosa aventuresca das novelas de cavalaria, que realça um idealismo extremo e um mundo de maravilhas estranhas à vida real (COELHO, 2010, p. 25).

Desse modo, como compreender a literatura infantil? Para tal, é importante repensar a relação literatura popular/literatura infantil. E isso implica a compreensão de que o que se produzia enquanto cultura popular ou folclórica: lendas, mitos, danças, jogos, todas a espécie de manifestação pública, tinha como expectador adultos e crianças. Como adverte Ariès (2012):

Até por volta do século XII, a arte medieval desconhecia a infância ou não tentava representa-la. É difícil crer que essa ausência se devesse à incompetência ou à falta de habilidade. É mais provável que não houvesse lugar para a infância nesse mundo. Uma miniatura otoniana do século XI nos dá uma ideia impressionante da deformação que o artista impunha então aos corpos das crianças, em um sentido que nos parece muito distante de nosso sentimento e de nossa visão (ARIÈS, 2012, p. 17). 
Pelo olhar de Ariès (2012) não havia uma representação da infância na iconografia do século XIII. A criança não era caracterizada por uma expressão particular e sim como um homem em tamanho reduzido. E o autor ainda explica que $a$ "recusa em aceitar na arte, a morfologia infantil, é encontrada na maioria das civilizações arcaicas”. Estes posicionamentos, de algum modo, podem dar indícios de que a criança não tinha um papel importante na sociedade e, talvez, essa fosse a razão de não haver uma literatura para a criança.

Então, ao observar esse hiato criança-família-sociedade presente desde a Idade Média, pode-se compreender a literatura infantil como processo que caminha junto às expressões populares, como produção cultural feita por adultos e adaptadas às crianças. Essa identidade é explicada ao se verificar que nessas sociedades, o "povo ou o primitivo e criança homem" não estruturavam seus conhecimentos de "modo histórico e racional" (COELHO, 1982, p. 19-21).

Conforme Coelho (1982), esta compreensão da realidade pela criança ou pelo homem rudimentar, manifesta-se pela consciência a-histórica da mesma, na qual estão situados, principalmente, por compreenderem a vida apenas no presente. E a autora esclarece que há uma diferença entre viver e conhecer uma coisa, ou seja, entre a certeza imediata e o conhecimento que resulta da experiência intelectual ou da técnica experimental.

Em vários estudos sobre as manifestações populares, crianças e adultos tomam parte das mesmas festas coletivas, danças, jogos, entre outros. Destarte, é precário delimitar a existência de uma literatura propriamente infantil, devido a não consciência, por parte da sociedade, da infância como importante etapa na vida humana.

Essas considerações sobre as origens da literatura popular servem como apoio para a compreensão de que a produção cultural para o povo e para a criança compartilham a mesma característica identitária. Isso implica considerar que a "popularidade" e "exemplaridade" estão dentre os fatores comuns na produção literária para adultos que se destinavam às crianças. E, como assevera Coelho (1982, p. 20): "todas as obras que se haviam transformado em 'clássicos' da literatura infantil, nasceram no meio popular (ou em meio culto e depois se popularizaram em adaptações) ".

Assim, para determinar a identidade entre "o popular e o infantil" deve-se refletir sobre a existência de uma reciprocidade entre uma mentalidade popular e infantil reunidas por um modo específico de apreensão da realidade exterior baseada na relação eu-mundo. Consequentemente, esta maneira de conhecimento da realidade ocorre de modo peculiar no povo e na criança: "através do sensível, do emotivo e da intuição". Que contrasta com 
o pensamento racional e da inteligência intelectiva da mente adulta e culta (COELHO, 1982, p. 20).

Esta relação biunívoca entre o conjunto da mentalidade infantil e o conjunto da mentalidade popular justifica a existência de uma linguagem poética usada como instrumento para transmissão de valores, exemplos e de padrões de comportamento. Decorre, portanto, que a literatura infantil encerra, desde sua constituição, um valor pedagógico ou um modo de auxiliar a criança a desenvolver suas potencialidades, bem como apoiá-la nas várias etapas de amadurecimento, no decorrer de sua infância.

Literária ou pedagógica? Essa ambiguidade persegue a literatura infantil. Permanece, na contemporaneidade, como atual controvérsia. Contudo, um dado comum é que ela nasceu como uma obra produzida para adultos e disponibilizada para crianças. Essas variantes suscitam a reflexão de que o objeto literatura infantil deve tocar o sensível, a emotividade, divertir e modificar a consciência de mundo. Por sua vez, enquanto instrumento manipulado por uma intenção educativa, situa-se no espaço pedagógico.

Esse aspecto dicotômico da literatura infantil não é simples de ser resolvido e talvez não possa sê-lo. No entanto, é importante considerá-lo na tomada de definição dos espaços-tempos de constituição da literatura infantil, que se consolida como gênero a partir do século XVII, mas que flutua nas narrativas primordiais e populares.

\subsection{Das fontes medievais da literatura popular-infantil}

$\mathrm{Na}$ tarefa de esticar o fio da história, observa-se que a literatura medieval surge da fusão entre o lastro oriental e ocidental, altamente influenciada pelo simbolismo religioso.

Isto posto, considera-se primeiro que obra As Isopets ou romance da Raposa são as fábulas de Esopo que ficaram conhecidas no século X, na França, relatadas em versos, e de aspecto moralizante. A familiaridade dos animais com comportamentos humanos permitiu a "invenção" de um personagem privilegiado, no século XII: a raposa. É o "surgimento" da epopeia animal o Romance da Raposa: um conjunto de vinte e sete relatos em versos octossílabos rimados, que mostra as aventuras e peripécias da raposa contra o lobo. Segundo a crítica, é a representação da organização da sociedade francesa da época.

As Disciplinas Clericalis, por sua vez, constituíam uma coletânea de trinta fábulas ou contos retirados de Calila e Dimna, Sendebar, Barlaam e Josafá. De autoria do padre 
Pedro Alfonso, cristão novo, foram narrativas mediadoras entre as fontes orientais e as ocidentais.

O Beato Raimundo Lúlio, alquimista e escritor catalão, foi o autor de $O$ Livro das Maravilhas e o Livro dos Animais (Bestiário). Exemplifica um modelo da novelística popular do século XIV e XV que tinha por personagem principal Félix, um peregrino e anotador das experiências que vai encontrando pelo caminho. A narrativa é uma novela episódica, como as caixas de surpresas, estruturada em diálogos. É considerado enciclopédico por conter fábulas, parábolas, exemplos, apólogos, de diversificado conhecimento.

A obra $O$ Livro de Petrônio e O Conde Lucanor foi considerada, junto ao Decameron, de Boccaccio, a criadora da prosa novelesca europeia. Em uma há um estilo rígido e austero, em outra, tem-se o conto pelo conto, a expressão realista da multiforme comédia humana, risonha, irreverente, em linguagem ágil.

A coletânea $O$ Livro de Exemplos surge na Espanha do século XIV e é composta por 300 contos de caráter moralizante, sentencioso, mais doutrinal que recreativo. No mesmo século surge $O$ Livro dos Gatos, um apanhado de 58 apólogos cujos personagens eram gatos e outros animais. É considerada tradução de alguma obra latina e, por este motivo, serve tão bem a qualquer nação da Idade Média. Há em alguns dos contos a presença astuta e irreverente da raposa. É uma sátira ao clero, aos ricos, aos ladrões, e a qualquer opressor do povo.

O Livro de Esopo é um estudo realizado em 1906, que circulou no século XV, chegando à atualidade em português medieval, cujo estilo satírico e irônico se perdeu em proveito da intenção moralizadora. Do mesmo século é o Horto do Esposo, escrito em letra gótica do século XV por um monge português anônimo, que trata de espiritualidade e diversão, contando histórias dos nobres e de feitos antigos, das coisas maravilhosas e de propriedade das animálias, e não fugindo ao modelo greco-romano. Um exemplo lembrado por Coelho (2010) é o da fábula do unicórnio, claramente influenciada por Calila e Dimna. Há a presença de contos exemplares, com lições de animais.

Ao que parece, a forma inaugural que mais teve fortuna foi a novela de cavalaria, de ordem ocidental, que influenciou novas produções literárias. Originou-se na Idade Média como gênero literário culto, no século XI, e pode ter tido como célula as canções de gesta. Tais narrativas eram contadas inicialmente em versos, e tinham o intuito de reverenciar os feitos dos guerreiros de Carlos Magno.

A novela de cavalaria alcançou a época renascentista e promoveu a criação de Don 
Quijote de la Mancha. O fato da idealização da mulher ser objeto de manipulação da Igreja Católica, através do culto mariano, favoreceu o surgimento e a divulgação dos contos de fadas. Coelho (2010) informa que as novelas de cavalaria resistiram aos séculos e às renovações literárias, e continuaram na tradição oral. Elas chegaram ao Brasil pelas mãos portuguesas no século XVII e, editadas em 1840, perpetuaram-se na cultura popular, além de encantarem as crianças. Outra característica importante associada às novelas de cavalaria é a influência no cordel nordestino brasileiro, que está repleto de histórias de Carlos Magno e de personagens a ele relacionados (COELHO, 2010, p. 37).

Encerram-se os estudos da Idade Média, pelo olhar de Coelho (2010), lembrandose da importância da obra de Bocaccio (século XVI) na novelística de transição entre esse período e o Renascimento. Essa obra é Decameron, cujo modelo de prosa ficcional,

\begin{abstract}
não só pela rara influência que exerceu na novelística popular da pósrenascença, mas principalmente porque, dando o modelo de uma prosa ficcional, realista e bem humorada, está na origem de uma prolífera produção popular de enredos cômicos, burlescos ou licenciosos, que têm ecos até hoje em nossa literatura popular e nos contos jocosos da literatura infantil (COELHO, 2010, p. 43).
\end{abstract}

É destaque para a autora, na obra de Bocaccio, não apenas o seu modo inovador mas a natureza de sua visão realista de mundo, expressa numa linguagem ágil e nova para a época, em contos breves e repletos de significação do real: histórias das aventuras amorosas ridículas ou exaltantes, fantasiosas ou realistas, trazendo os vícios, as vaidades e as misérias da condição humana.

Essa obra se destaca pela linguagem, com um universo criado pela narrativa regada à ironia, ao humor e à inteligência crítica do autor, e imprime uma nova maneira de narrar. Daí ela ser considerada uma obra prima da literatura universal.

No entanto, é importante notar que todas essas escritas medievais, orais em princípio, influenciaram o surgimento dos copistas que tinha a função de registrá-las, pois ainda não havia a imprensa, que disseminou a produção cultural. Os ateliês dos copistas surgiram no século XIV, na França, no interior dos mosteiros que recebiam encomendas das cortes e dos grandes senhores (COELHO, 2010, p. 45). E calcular o quanto essas fontes influenciaram a produção literária para as crianças é uma tarefa homérica. 


\subsection{A consolidação da literatura infantil}

A fonte de onde se observa a constituição da literatura infantil é continua e inesgotável. Por isso, ao alcançar os portões da Idade Moderna, observa-se a ampliação nas formas de ver e de estar no mundo. Nesse período histórico, a literatura ocidental adquire contorno próprio e alcança patamares mais elevados em suas formas e imagem do mundo. Entende-se a Idade Moderna como o período que vai da Era Clássica (século XVI-XVIII) à Era Romântica (século XIX-XX). Sua principal marca: a ascensão da civilização humanista-liberal-cristã-burguesa, que chega ao apogeu no século XIX e declínio no início do século XX.

A palavra de ordem para o Renascimento é mudança. A ampliação dos horizontes a que se refere Coelho (2010) significou a radicalização de um complexo movimento cultural que se propagou pela Europa Ocidental, através da constituição das nações, das transformações de ideias, as invenções e as descobertas. A propagação desse novo vigor se deu pelo progresso da arte da navegação que, a partir das travessias marítimas, da expansão do comércio, da invenção da pólvora, ampliou os limites e o domínio do mundo pela Europa.

Todavia, o ponto alto desse movimento de mudança é o surgimento da imprensa e a publicação da Bíblia. Este ato redimensiona o humano para a eternidade, pela perpetuação da palavra escrita. $\mathrm{O}$ ato humano de prender em algo concreto suas experiências essenciais estabelecem elo entre o passado e antecipa o futuro. Então, "o livro é uma das presenças mais significativas no processo cultural que tem início no Renascimento e prossegue até hoje" (COELHO, 2010, p. 51).

Esse fato é realmente fundamental para a compreensão das mudanças culturais e indica transgressões. Como afirma Chartier (1998), “em meados da década de 1450, só era possível reproduzir um texto copiando-o à mão, e de repente uma nova técnica, baseada nos tipos móveis e na prensa, transfigurou a relação com a cultura escrita" (CHARTIER, 1998, p. 7).

A invenção da imprensa representou um divisor de águas no modo de produzir cultura na Europa e contribuiu para a difusão da nova imagem de homem e de mundo devido à presença do humanismo no seio do Renascimento, quando a humanidade redescobre a Antiguidade através do acervo cultural greco-romano, disponibilizado pela migração de intelectuais após a queda de Constantinopla.

Porém, a questão do acesso à cultura letrada deve ser questionada. Esse impulso inovador verificado no período foi sentido de modos diferenciados entre a camada popular 
e a dominante. Como esclarece Coelho (2010), houve uma resistência por parte da primeira, em relação às mudanças. Assim, as camadas populares se mostraram mais conservadoras e continuaram a se "alimentar" das histórias oriundas da Idade Média, que circulavam oralmente e em manuscritos. Deve-se, portanto, pensar sobre a questão do acesso ao mundo letrado e no analfabetismo como impossibilidades naturais à época.

Por sua vez, a literatura culta tem grandes representantes: Bocaccio, Camões, Bernardim Ribeiro, Rabelais, Garcilaso de la Veja, Rosard. A autora expõe que na literatura popularizante são registradas apenas quatro obras. Nessas obras, a matéria é semelhante à das narrativas medievais, mas com nítida superioridade estilística. São as coletâneas dos italianos Caravaggio, Basile, Croce, e do português Trancoso. Relatos exemplares típicos da Idade Média, de origem oriental, que comporão o acervo da Literatura Infantil (COELHO, 2010, p. 53).

Tais coletâneas têm como características comuns o fato do recolhimento das mesmas ocorrer a partir de relatos orais ou de narrativas circulares, por exemplo:

1. Noites Agradáveis - de Gianfrancesco Straparola da Caravaggio, escrita na Itália em 1554, difundida na Espanha e em Portugal.

2. Contos de Trancoso - do português Gonçalo Fernandes Trancoso, século XVI. Conto dos Contos ou Pentameron - de Giambatiste Basile. Esse trabalho foi apontado como mais importante que o de Caravaggio.

3. Astúcias Sutilíssimas de Bertoldo - de Giulio Cesare Croce, da segunda metade do século XVI.

4. Pedro Malasartes - figura popular nas narrativas medievais de origem ibérica.

A colheita das narrativas em cada autor citado se dá de modo específico. Por exemplo, Caravaggio recolhe-as das que circulavam oralmente nas províncias italianas e em vários dialetos. Esse trabalho foi importante para a propagação das fontes inaugurais da novelística europeia nos séculos XVI e XVII. As narrativas de Trancoso, do século XVI, por sua vez, são as coletâneas de contos recolhidos da tradição oral, de grande divulgação, inclusive no Brasil de 1618. Tais contos pertencem à literatura exemplar da Idade Média e caracterizam-se por fundir a vertente clerical à folclórica, em um estilo filosofante, de redação simples e direta.

O trabalho de Basile reflete o interesse comum na Itália de 1600 pelo folclore, pelos cantos e canções populares que visavam à valorização do dialeto de cada região. Assim, o autor descobriu as maravilhas linguísticas do dialeto napolitano e aplicou-as na 
égloga Musas Napolitanas, registro fiel da vida popular napolitana. Os contos de fadas ou de encantamentos que circulavam na região napolitana foram descobertos também por Basile. Curiosamente, sua obra foi traduzida para nove idiomas e grande parte dela está na origem dos contos de Perrault.

A obra de Croce, por sua vez, faz surgir uma personagem emblemática, que é Bertoldo. Bertoldo é um jovem que consegue escapar de perigos ao responder, astutamente, aos reis, rainhas e corte. Essas narrativas tornaram-se populares em Portugal a partir de 1783. A última coletânea destacada é Pedro Malasartes.

Tais narrativas procedem de lugares diversos da Europa, por isso, são chamadas de ciclo narrativo Malasartes. A figura Malasartes é popular nas narrativas medievais de origem ibérica. Este ciclo narrativo tem em Malasartes um herói sem caráter, um pícaro descendente de pícaros espanhóis, um burlão sem escrúpulos, e encontra-se presente na obra de Grimm, de Andersen, nos fabulários medievais e adaptados. O Malasartes brasileiro pertence à origem ibérica, integra-se à cultura popular e figura na literatura infantil, sendo um personagem que gerou muitos episódios e mereceu vários estudos.

Essas narrativas, ao que parece, foram importantes no panorama do Renascimento, período que precedeu à constituição da Literatura Infantil. Além dessas, a autora observa os aspectos culturais portugueses à época do "descobrimento" do Brasil, que foi o período das grandes navegações e, em decorrência disso, a impregnação de outros elementos na cultura portuguesa, ou seja, "o processo de internacionalização das relações econômicas é simultâneo com a internacionalização das relações culturais" (COELHO, 2010, p. 58).

Sobre as estruturas culturais postas em movimento nesse período, está a influência do humanismo ou latinização em relação ao português. Mais uma vez, faz-se presente a marcação "culto" versus "popular" evidenciada na relação do português de Camões, culto, e o português de Fernão Lopes, considerado popular. Então, um certo bilinguismo era observado: o filho do nobre era alfabetizado em latim, enquanto o povo continuava falando o português corriqueiro, o que aprofundava e segregava as relações sociais. Segundo a autora,

é essa uma literatura que resulta da valorização da Fantasia e da Imaginação e que se constrói a partir de textos da Antiguidade Clássica ou de narrativas que viviam oralmente entre o povo. Tal "tradição", popularizante ou erudita, redescoberta ou recriada por escritores cultos, contrasta vivamente com a alta literatura clássica produzida nesse momento: o teatro de um Corneille ou de um Rancine, um Malherbe; a oratória de um Bossuet; a teorização poética de um Boileau. (COELHO, 2010, p. 75). 
Para se perceber com maior nitidez a relevância da Literatura Infantil como instrumento cultural, é preciso compreender o momento sócio-político-cultural pelo qual passava a França do século XVII. Observa-se que após a turbulência política e o desequilíbrio que eclodiu com o Renascimento e devido a guerras civis, tornou-se imperioso promover a harmonização, meta que foi denominada como estabelecimento da ordem nacional. Ou seja, mudança no modo de pensar, na sociedade e nos costumes em geral.

Essa ordem nacional baseava-se no princípio humanista de que, através da Razão, o homem podia conhecer a Verdade, a Beleza e o Bem. É importante para a compreensão do pensamento humanista e da arte Clássica em voga, abordar as duas forças que eles constituem: a grandeza do Homem, dono da Razão e do Conhecimento, de um lado, e a obediência aos modelos dos antigos, por outro. Ou seja, a tendência filosófica em vigor compreendia o racionalismo na literatura que defrontava duas forças opostas: "preciosismo e realismo libertino, correntes de pensamento responsáveis pelas diferenças de temas ou problemas que marcam a produção literária da era clássica” (COELHO, 2010, p. 76).

Na visão de Coelho (2010), estas duas tendências - "romance precioso" e "romance realista libertino" - significaram o tônus da produção literária da primeira metade do século XVII. A partir dessas duas tendências literárias, manifestaram-se produções de prosa narrativa literária exuberantes e fantasiosas que contrastavam com os gêneros considerados nobres à época: o teatro e a poesia.

A esse respeito, a obra El Ingenioso Hidalgo Don Quijote de la Mancha, de Cervantes, publicada entre 1605 e 1615, representa bem a tensão dialética entre o idealismo da vida heroica e o realismo da vida prática, presente na Espanha de Felipe III. A obra de Cervantes parodia a novela de cavalaria de 500 anos antes e tem um herói paradoxalmente forte e fraco.

Tal ideal de grandeza humana é fundado no estoicismo cristão, que é o humanismo do século XVI, herdado pelo século XVII, cujas paixões são dominadas pela razão. A mudança desse ideal cavalheiresco ocorre de modo sensível na metade deste século através do teatro de Molière e das fábulas de La Fontaine que demonstram, entre outras coisas, a descrença no estoicismo cristão. 


\subsection{Dos coletores de narrativas}

É nesse ambiente dialético de mudanças e descrenças, no auge do Renascimento clássico, que surgem as "obras clássicas" da literatura infantil ocidental. Obras que valorizam a fantasia, o imaginário e o maravilhoso e contrastam assim, com a atitude racionalista preconizada pela alta cultura.

Dentre os grandes nomes que deram forma às fabulas e contribuíram para a consolidação da literatura infantil, estão La Fontaine e Charles Perrault.

A obra de Jean La Fontaine (1621-1692) deu forma definitiva na literatura ocidental às fabulas. Isto significa dizer que a característica determinante em sua obra resulta do uso de argumentos gregos, latinos, franceses, narrativas medievais e renascentistas, parábolas bíblicas, contos populares, o que diferencia a matéria literária de suas fábulas. E estas, por sua vez, consistem na reunião de doze poemas narrativos que constituem os doze livros de trabalho. Tais poemas expõem uma situação que se encerra com uma moralidade, ou seja, divertem e instruem.

E o que dizer das personagens em La Fontaine? Por serem cifrados, os textos de La Fontaine embutem intenções de seus personagens. No entendimento de Coelho (2010), ao escrever $O$ Lobo e o Cordeiro e A Raposa e o Esquilo, La Fontaine faz referência a um certo amigo afastado de suas funções e aprisionado, injustamente. São, pois, simbólicos os seus personagens. A situação do Leão em suas fábulas refere-se ao poder absolutista, à tirania de reis impiedosos e orgulhosos. Esses personagens simbolizam a autoridade e o ócio da corte. A Raposa, por sua vez, assume papéis diversos: ora é o cortesão bajulador, astuto; ora o burguês enriquecido e tomado como nobre astuto e cínico (COELHO, 2010, p. 84).

Charles Perrault (1628-1703) é o segundo grande nome do período. Contemporâneo de La Fontaine e seu opositor na "Querela dos Antigos e Modernos"5, entra para a História da Literatura Universal como autor de uma obra de literatura popular desvalorizada pela estética de seu tempo, e a despeito disso, transforma-se em um dos maiores sucessos da literatura para a infância. Destaca-se de sua produção a obra $O s$

\footnotetext{
${ }^{5}$ Nelly Novaes Coelho ressalta que Perrault era católico convicto, intelectual de destaque nos círculos de Luís XIV, advogado do ministro Coubert, e muito polêmico. Escreveu a obra cristã de cunho moral: Saint-Paulin, e, ao ler na Academia Francesa seu texto "O Século de Luís, o Grande", provocou a conhecida polêmica "Querela dos Antigos e Modernos" que marca a crise do classicismo.

${ }^{6}$ Segundo descrito por Erich Auerbach, fabliau, plural fabliaux, significa narrativa, em geral curta e em octossílabos, característica da Idade Média francesa, cuja finalidade era o mais das vezes a diversão e a lição de moral.
} 
Contos de Minha Mãe Gansa, que, com o passar do tempo, foi divulgada como leitura para crianças.

Para Coelho (2010), a obra de Perrault não se limita à expressão das tensões sociais, embora seus contos tenham sido organizados em torno de interdições ou permissões que estruturam a família e a sociedade. Indo além, eles constituem um rico repertório de experiências ancestrais, um vasto reservatório de condutas possíveis, um corpo de censuras sociais expresso de modo simbólico.

A figura de Perrault era tida como controversa por sua postura política e social. Ele apreciava romances preciosos de cunho sentimental e tinha a mulher como personagem central. Ou seja, estava mais para o popular do que para o clássico, em muitas situações. A infância, entretanto, não estava no centro da preocupação de sua obra, em princípio. Somente a partir da publicação de A Pele do Asno, em 1694, que se manifesta uma produção literária para crianças.

Todavia, na coletânea Os Contos de Minha Mãe Gansa, a personagem central é retirada do fabliaux ${ }^{6}$, o que indica sua referência aos contos populares. A personagem Mãe Gansa universalizou-se como contadora de histórias e adquire um nome diverso em cada região. Assim, Mère l'oye se apresenta também como Velha Fiandeira. Perrault passa a escrever em prosa, em linguagem ingênua e direta.

Pelo olhar de Coelho (2010) e outros estudiosos, há muito que se pontuar sobre a obra de Perrault. Suas publicações em 1697 envolvem: “A Bela Adormecida no Bosque, Chapeuzinho Vermelho, O Barba Azul, O Gato de Botas, As Fadas, A Gata Borralheira ou Cinderela, Henrique: o topetudo e O Pequeno Polegar". A autora assevera que estes contos circularam na França como contos de fadas, muito embora o elemento fada não faça parte de muitos deles.

A característica principal desses contos é o aspecto maravilhoso, ou seja, existem em um espaço diferente do real, por existirem num espaço maravilhoso. Em Chapeuzinho Vermelho, por exemplo, o elemento maravilhoso é representado pelo lobo falante, em $O$ Gato de Botas, o gato tem comportamento humano. O elemento fada, como maravilhoso, aparece em contos como A Bela Adormecida e Cinderela.

Outro aspecto formidável na obra de Perrault diz respeito à moralidade, que se veste de utilidade, ou seja, a artimanha da personagem que se encontra em desvantagem para vencer outra em posição de autoridade. Esta situação evidenciava a realidade da época, na figura do burguês que trabalha, realiza e conquista.

O elemento simbólico também é atrelado à obra de Perrault, isto é, a relação entre os contos e os processos litúrgicos populares arcaicos. Os contos de Perrault são divididos 
em duas áreas: contos ligados aos rituais das estações e contos de origem iniciática. Assim, ao primeiro grupo ligado aos rituais das estações fazem parte: As Fadas, A Bela Adormecida, Cinderela, Pele de Asno e Chapeuzinho Vermelho. Cada conto é como um mito ligado a um ritual antigo, esquecido.

No caso, as personagens seriam heroínas de narrações religiosas, que representaram rainhas ou sarcedotisas em velhas liturgias populares, como: a dos Pedidos do Ano Novo, da Epifania, as Rondas e Pompas do Dia de Cinzas e do $1^{o}$ de Maio (quando a primavera europeia eclode poderosa). O conto As Fadas, explica Coelho (2010) pode estar relacionado ao costume de Ano Novo de tratar as fadas com deferência, com oferendas de bebidas e iguarias, em "cerimônias" de agradecimento às fadas ou aos gênios.

O segundo grupo de contos: O Pequeno Polegar, Barba Azul, Henrique de Topete e o Gato de Botas, está ligado à origem iniciática e são de interpretação delicada e incerta. E, como afirma Coelho (2010), são relacionados à questão social de iniciação, à formação do sagrado do ser social, através de um ensinamento ou treinamento mágico-religioso, para desempenhar seus deveres e papel no grupo, clã ou tribo. No Pequeno Polegar, exemplifica a autora, há a iniciação de transformação do menino em homem; para a formação da mulher no papel de esposa em Barba Azul, para ensinar as leis do casamento para homens em mulheres em Henrique de Topete; e em Gato de Botas, ensinar, ao futuro chefe, as exigências do seu cargo (COELHO, 2010, p. 95).

Então, certos contos maravilhosos podem ser considerados restos de antigos mitos iniciáticos. A autora demonstra que nos rituais de iniciação, alguns comportamentos são comuns: provas, tentações, simulacros de morte, disfarces em forma de animais, cenas de prestidigitação. Esses aspectos podem revelar alguns traços observados em ogres e no canibalismo, em objetos mágicos, metamorfoses, animais que falam.

A Saintyves ${ }^{6}$ são relacionados os estudos acima, apontados por Coelho, em relação à interpretação da obra de Perrault. Entretanto, a autora ainda acrescenta que vários "estudiosos dos mitos e sua permanência nas narrativas antigas, apoiados na teoria solar, interpretam certas personagens de Perrault como personificações da Aurora". Coelho afirma que a Aurora é ameaçada pelo Sol voraz que pode também engoli-la. Um exemplo relacionado é o de Chapeuzinho Vermelho: a Aurora que será engolida pelo lobo.

Outro aspecto apontado pela autora quanto à interpretação da obra de Perrault, diz respeito às possibilidades de análises dentro do campo da psicanálise. Para tanto, ela

\footnotetext{
${ }^{6}$ Estudado por Nelly Novaes Coelho.
} 
lembra as contribuições de Eric Fromm em sua obra A Linguagem Esquecida, que a partir de Freud e Jung, examina a natureza da linguagem simbólica dos contos. A autora cita novamente Chapeuzinho Vermelho como exemplo do conflito macho-fêmea existente no mito edipiano, afirmando: “O estudo global da Linguagem Esquecida ilumina, para nosso entendimento, uma série de fenômenos importantes para maior valorização da literatura narrativa simbólica passados despercebidos" (Coelho, 2010, p. 95).

A autora registra a importante presença do trabalho de Bruno Bettelheim (1996) A Psicanálise dos Contos de Fadas, afirmando que os contos de Perrault: Chapeuzinho, A Bela Adormecida e A Gata Borralheira são analisados por tal autor pela perspectiva freudiana e tem por base o complexo de Édipo. É, ao mesmo tempo, uma análise mítica e psicanalista. Segundo Bettelheim “o mundo só está vivo para a pessoa que desperta para ele. Só o relacionamento com os outros nos desperta do perigo de deixar nossa vida adormecida" (BETTELHEIM, 1996, p. 203).

Os três contos iniciais de Perrault: "Griselidis", "Os Desejos Ridículos" e "Pele de Asno" tiveram como fonte os fabliaux. Os demais tiveram fontes específicas, assim representadas:

1. A Bela Adormecida no Bosque: a autora cita a coletânea Ancienne Croniques d'Angleterre e que circulou nos países do sul da Europa, no século XIII, com episódios romanescos semelhantes ao de Bela, entre o cavaleiro Troylus e a bela Zelladine. E no folclore brasileiro, a narrativa em verso A Princesa do sono sem fim.

2. Chapeuzinho Vermelho: de fonte incerta, surge em vários folclores. Pode estar vinculada ao mito grego de Cronos, que engole os filhos e que esses saem do estomâgo, sãos e salvos, milagrosamente e o enchem de pedras.

3. O Barba Azul: teria origem na lenda do tesouro de Ixion, da mitologia grega.

4. A Gata Borralheira ou Cinderela: tem ancestral registrado por Basile, em Pentameron: La Gata Cenerentola ou o tema da transformação da moça feia em bela. Esta temática da metamorfose da feiura em beleza é bastante antiga e recorrente em diversas narrativas.

5. Henrique, o topetudo: é tido como variante do conto A Bela e a Fera.

6. O Pequeno Polegar: origem incerta. A fonte utilizada pode ser da tradição contemporânea a Perrault. Diz respeito a um ser minúsculo, 
nascido de modo milagroso, incomum, de grande auxílio aos pais, muito embora pequeno e frágil.

Justifica Coelho (2010) que

a universalidade de certos temas ou contos, presentes entre raças tão distantes,
ou de civilizações tão diferentes, é um fenômeno que tem surpreendido os
pesquisadores. No entanto é uma das provas que existe (ou existiu) um fundo
comum a que pertencemos todos e do qual perdemos a consciência há muito.
Permanecem no mistério as circunstâncias que levaram tais contos e
narrativas de um ponto a outro do globo, em tempos tão recuados, em que era
tão difícil vencer as distâncias... daí a importância étnica e psicológica desses
contos tradicionais, como documentos incontestes de um período em que a
comunicação entre os homens se fazia predominantemente por meio
emocional (COELHO, 2010, p. 100).

Esses aspectos citados pelos estudos de Coelho (2010) indicam a riqueza temática da literatura infantil, por um lado. Igualmente, evidenciam a existência de um fundo comum no qual todos estão presentes e como esse fundo comum, transmutado em contos e narrativas, se espalhou para pontos tão distantes. Isto também justifica o sucesso dos contos de fadas verificado até o fim do século XVIII (COELHO, 2010, p. 100).

Outro nome que merece referência é o de François de Salignac de la Mothe ou simplesmente, Fénelon (1651-1715), nobre e padre. Sua obra teve influência no modo de produzir literatura infantil como instrumento que visasse a diversão e a instrução de modo indireto. É pioneiro no estudo sobre educação e escreve o Tratado de Educação para Meninas, em 1687, demonstrando sua vinculação ao movimento de evidenciação da mulher no século XVII.

A obra mais divulgada de Fénelon é a Aventuras de Telêmaco, que seguia os moldes literários convencionais da época, sendo que a temática presente na narrativa é a busca pelas origens, pelo autoconhecimento.

Isso pode implicar que as manifestações literárias produzidas naqueles séculos formadores da literatura ocidental, são impulsionadas por uma intenção didática, moralizante ou educadora. Como exemplo, Coelho (2010) trata da obra em prosa didática de Francisco Rodrigues Lobo, Corte na Aldeia e Noites de Inverno, destinadas a educar a nova burguesia aristocratizada. $\mathrm{O}$ intuito era instruir sobre etiqueta social, cultura e boas maneiras da nobreza da Corte.

É possível relacionar este relato de Coelho (2010) com o que afirma Chartier (2004) sobre a questão da civilidade, no sentido de dotar a nova classe social, a burguesia, de modos externos de polidez; assim, projetos e tratados educacionais foram arquitetados. 
O século XVIII é marcado pela consolidação da burguesia e tem como expressão o novo gênero literário que é o romance moderno. Destacam-se, em princípio, duas obras narrativas: Robinson Crusoé (1719), de Daniel Dafoe, e Viagens de Gulliver (1726), de Jonathan Swift. O período de surgimento dessas obras é marcado por grandes transformações do mundo clássico, aristocrático, baseado nos privilégios de sangue, nobreza e poder, para o mundo romântico, burguês. Este, por sua vez, tinha como regras as relações de interesse pelo individualismo, produção, trabalho, mercantilismo, progresso, que substituíam guerras por tratados e alianças de paz (COELHO, 2010, p. 121).

Mediante o exposto, o que esperar dessas narrativas? As respostas dadas por estudiosos como Coelho (2010), Arroyo (2003) e Góes (1984) contemplam os aspectos que elas encerram. O que significa afirmar que em Robinson Crusoé se destaca a representação do real.

A obra de Daniel Defoe, na visão dos estudiosos acima citados, pode ser considerada como autobiográfica e memorialista. A linguagem em primeira pessoa, clara e concisa, aborda os problemas de modo direto. O cerne da temática é a exaltação da energia criadora do homem, que o impulsiona a agir no mundo. Ela é recorrente em todas as versões ou adaptações submetidas.

Os valores evidenciados nesse herói em Defoe giram em torno da ênfase dada à responsabilidade do indivíduo perante o que ele é, sua consciência e responsabilidade, que nasce com a liberdade de espirito e de pensamento. Contemporâneo de Defoe, Jonathan Swift (1667-1745) foi considerado um grande escritor de sua época. Como exclérigo da Igreja, humanista, de temperamento agressivo e amargo, participou de movimentos contra a Inglaterra, na questão da opressão dos seus conterrâneos irlandeses, em 1720. Em 1726, escreveu a obra que o imortalizou, ou seja, Viagens de Gulliver.

As várias versões pelas quais essa obra passou tornaram-na uma alegoria e não mais uma obra de intencionalidade, como de princípio. Inicialmente, o foco do autor baseava-se na aquisição do saber e da cultura.

As adaptações pelas quais passou a obra As Viagens de Gulliver, fizeram desaparecer o tom amargo e crítico contido na alegoria da luta pelo poder e enfatizaram apenas o lado pitoresco das aventuras. É possível que as versões dessa obra tenham caído no gosto do público infanto-juvenil, enquanto, em sua versão original, continuava agradando os adultos por encerrar os valores civilizados da burguesia que se consolidava (COELHO, 2010, p. 131). 
No contexto social, político, econômico e cultural da época se evidenciava o processo de confirmação da burguesia. Inclui-se nessa perspectiva o modo como o novo modelo familiar nuclear se delineava, no modo como a criança passou a ter importância e cuidados. E, além de tudo, a literatura que se delimitava precisava cumprir o papel social de formação do filho do burguês. Esse sentimento alcança o século XIX, quando se evidencia a preocupação da produção literária ideal para um modelo de infância, seguindo os passos da descoberta da criança. Essa leitura precisava ser formadora de sua mente e de sua personalidade.

A literatura infantil produzida na época estava dividida de acordo com tendências ou espécies, "para melhor compreensão de sua natureza e como atrairiam os pequenos leitores". As narrativas foram divididas entre as Narrativas do Fantástico-Maravilhoso, Narrativas do Realismo-Maravilhoso ou Mágico, Novelística de Aventuras, Narrativas do Realismo Humanitário e Narrativas Jocosas ou Satíricas (COELHO, 2010, p. 153).

Deste modo, vários autores são destacados de acordo com cada modalidade acima, pelos estudiosos da literatura infantil. Da primeira modalidade, evidenciam-se os Irmãos Grimm, Jacob (1785-1863) e Wilhelm (1786-1859) Grimm e Hans Christian Andersen (1805-1075). As Narrativas do Fantástico-Maravilhoso, de fundo folclórico ou popular, derivam do mundo da fantasia, perfeitamente reconhecível como diferente do mundo real, conhecido.

Os Irmãos Grimm são filólogos, grandes folcloristas, estudiosos da mitologia germânica e da história do Direito alemão. Recolhem diretamente da memória popular as antigas narrativas germânicas conservadas por tradição oral. Buscando encontrar as origens da realidade histórica "nacional", os pesquisadores encontram a fantasia, o fantástico, o mítico... e uma grande Literatura Infantil surge para encantar crianças do mundo todo. O material folclórico recolhido pelos Irmãos Grimm entre 1812 e 1822 é publicado como a obra Contos de Fadas para Adultos e Crianças. A obra consta de histórias muito conhecidas, como A Bela Adormecida - Os Músicos de Bremen - Os Sete Anões e a Branca de Neve - O Chapeuzinho Vermelho - A Gata Borralheira, entre outras. Contudo, o modo de compreensão do homem e do mundo são outras, bem como o modo, as maneiras e os objetivos do homem. E essa mudança é também característica do Romantismo, que agrega um modo, um sentido humanitário ao mundo, que tem reflexo na arte, na literatura e nos costumes.

Essas considerações são determinantes para a compreensão das adaptações literárias realizadas pelos Irmãos Grimm. Confronta-se o final da Chapeuzinho Vermelho de Perrault e dos Irmãos Grimm. No primeiro, não se observa ou não há uma preocupação 
quanto ao impacto das cenas violentas nas crianças, modo perfeitamente integrado com a época: culto às tradições populares. No segundo, quando as duas personagens saem vivas da barriga do lobo, há uma demonstração de esperança e confiança na vida, bem ao molde do humanismo.

Como compreender a natureza dos contos dos Grimm? Em primeiro lugar, essas narrativas são de ordem do maravilhoso e do fantástico, e são diferentes espécies literárias. Assim, é interessante perceber que o elemento "fada" não aparece nas narrativas, mas essas são: ora contos de encantamento, por apresentarem transformações, metamorfoses por encantamentos; ora contos maravilhosos, por apresentarem o elemento mágico, o sobrenatural, integrados naturalmente nas situações apresentadas. Há também fábulas, lendas, contos de enigmas e mistério.

Quanto aos elementos estruturais das narrativas de Grimm, predominam nas estórias “um só núcleo dramático do qual dependem todos os episódios que compõem a intriga". Narrativas de estrutura complexas são raras nas coletâneas de contos populares.

Assim, afirma a autora que a característica básica de tais narrativas é a de "apresentar uma problemática simples e bem configurada, desenvolvida em unidades narrativas que se sucedem praticamente iguais entre si” (COELHO, 2010, p. 153).

Dentre as características importantes dos elementos estruturais das narrativas de Grimm, podem ser destacadas a técnica da repetição, as constantes dos contos maravilhosos, a compreensão da metamorfose, o uso de talismãs, a força do destino (fatalidade), o desafio do mistério ou interdito (tarefas sobre-humanas, heroísmo), esoterismo pela reiteração dos números 3 e 7, magia e divindade, e os valores ideológicos.

Hans Christian Andersen é o segundo e importante exemplo dentro da modalidade das narrativas do fantástico-maravilho. Poeta e novelista, inicia sua produção literária vinte anos após os iniciadores do nacionalismo romântico popular. A atmosfera política e cultural encontrada por ele resulta do amadurecimento da geração anterior. Ele preocupase com a sensibilidade exaltada pelo Romantismo, e de maneira terna, retrata-a em suas famosas estórias infantis.

A simplicidade de Andersen está representada em suas obras, tais como: $O$ Patinho Feio, O Rouxinol e o Imperador da China, O Soldadinho de Chumbo, A Pequena Vendedora de Fósforos, para citar alguns exemplos. Simplicidade, não confundida por ingenuidade, mas carregada de significações. Embora muitas de suas histórias se desenrolem no mundo fantástico, a maioria delas está ligada ao cotidiano. Cotidiano marcado por contrastes sociais da sociedade industrial em detrimento da vida operária. 
De origem humilde, cristão convicto, Andersen deixava entrever em sua obra toda uma especial carga emotiva. No entanto, pode-se afirmar que não se tratava de um romântico piegas, mas um delator das condições sociais antagônicas de sua época, que tentava explicitar os padrões de comportamento exigidos pela sociedade patriarcal, liberal, cristã e burguesa.

Ou seja, sua obra evidenciava os valores contraditórios da sociedade burguesa. Assim, por exemplo, em A Pastora e o Limpador de Chaminés podia-se observar a defesa dos direitos iguais, pela anulação das diferenças de classe. Em $O$ Patinho Feio e A Pequena Vendedora de Fósforos fica evidente a valorização do indivíduo por suas qualidades intrínsecas e não por seus privilégios ou atributos exteriores. Nos vários títulos pode-se observar ainda: a ânsia por expansão do eu, a crença na superioridade das coisas naturais em relações artificiais, sátiras, consciência da precariedade da vida, valorização da submissão da mulher.

Portanto, uma das importantes peculiaridades na obra de Andersen, pelo olhar dos estudiosos, em especial Coelho (2010), é a mescla que realiza entre o maravilhoso e o realismo. Na maioria das narrativas, as personagens, os espaços e problemáticas são retirados do cotidiano, da realidade circundante. O elemento mágico está presente em tudo, sem que haja uma barreira entre o real e a fantasia. $\mathrm{O}$ universo de Andersen é cheio de maravilhoso, sobrenatural, mitos, fábulas, lendas e novelas ancestrais. De seres prodigiosos podem surgir humanos que precisam ser valorizados. Ou seja, a ternura e a violência são dois polos de onde fluem suas histórias.

Os heróis de Andersen são sempre derrotados no final, diferentemente das personagens de Grimm. Essa fatalidade pode indicar sentimento de passividade, de conformidade baseadas na perspectiva de fundo moralizante e religioso, e como relacionala à atual realidade? Coelho afirma:

\footnotetext{
acrescentamos apenas que, se pretendemos que as crianças apreendam a essencialidade da literatura pelo mergulho vertical na linguagem literária, os padrões de comportamento, que encontrarão em grande parte da produção de Andersen, não vão ajudá-las em nada a se situarem neste novo mundo que surge. Por um lado, porque Andersen enfatiza a emotividade como único fulcro dos pensamentos e ações do homem; por outro, porque essa emotividade (tipicamente romântica) leva à contemplação ou à fruição passiva das coisas (COELHO, 2010, p. 169).
}

Enfim, apesar disso, não cabe a desvalorização da obra de Andersen para o público do século XXI, mas um olhar atualizado do seu profundo humanismo e emotividade comovedora. 
Da segunda modalidade, por sua vez, estão presentes Lewis Carrol (1832-1898), James M. Barrie (1860-1937), Collodi (1826-1890) e o Barão de Münchhausen.

A característica marcante das Narrativas do Realismo-Maravilhoso ou Mágico é que ela retrata a magia que, de repente, ocorre no mundo real, cotidiano e familiar. Esse algo mágico ou absurdo influencia os acontecimentos e modifica o mundo normal. Se em Andersen essa característica já era notada, em Lewis Carrol ela se mistura ao elemento nonsense.

Numa tradução simples, nonsense relaciona-se ao que não faz sentido. Em relação à obra de Carroll, tal característica significa que o excesso de racionalismo vitoriano será questionado. O nonsense em Carroll está vinculado, então, às raízes do fantasioso. Afirma Coelho:

\begin{abstract}
Nas raízes do fantasioso universo de Alice no País das Maravilhas ou No País do Espelho, é esse nonsense que encontramos. É a lúcida consciência do absurdo de regras e valores absolutos que, instituídos em sistema, regem a vida do homem. E a denúncia desse absurdo se faz através de outro absurdo: o que resulta da subversão não só das leis naturais que nos regem, mas principalmente da linguagem. Indiscutivelmente, o grande valor literário de Alice no País das Maravilhas está em sua invenção da linguagem, correspondendo essencialmente à natureza das fantásticas aventuras ali concretizadas (COELHO, 2010, p. 173).
\end{abstract}

Pelo exposto acima, dentre os vários aspectos da genialidade de Carroll, destacase o modo como subverteu a linguagem, mesmo que a sua escrita dificulte a tradução e a adaptação. Com o jogo lógico-semântico rompe-se com o equilíbrio do real, a partir de sua representação linguística. Outro aspecto da inventividade de Carroll é o emprego da relativização das coisas, a partir do problema do tamanho. E, segundo os estudiosos adotados aqui, é possível que Carroll tenha se valido da fotografia para realizar as metamorfoses, pois o aparecimento e desaparecimento de coisas ou partes delas se relacionam tanto ao fantasioso quanto à técnica da revelação.

Ao romper com a estrutura lógica, a obra de Carroll torna-se sintomática quando surge contrária ao racionalismo e aristocratismo da sociedade do século XIX. A obra de Carroll surge para crianças e vai se tornando para adultos.

A obra de Barrie que se destaca é Peter Pan, de 1905. O princípio básico dessa obra é o menino que se recusa a crescer. A personagem Peter Pan aparece pela primeira vez no conto O Pequeno Pássaro Branco, em1896. Esta obra foi transformada em roteiro para cinema em 1920, que foi recusado. Walt Disney realizou a filmagem com alterações, anos depois. Traduzido em vários idiomas, no Brasil influenciou a obra de Monteiro 
Lobato que incluiu esta personagem como o criador do pó de pirlimpimpim no Sítio do Pica-pau Amarelo.

Carlo Lorenzini ou Collodi, o terceiro nome da relação, foi um importante jornalista italiano, que escreveu Pinocchio. Antes de dar luz a essa obra, o autor escrevia para o público infantil adaptando contos de Perrault e de outros autores para crianças. Escreveu também livros didáticos e livros para adultos. Em 1881, publicou o folhetim $A$ Estória de um Boneco, a que deu prosseguimento em outras edições, das aventuras de um menino. Por fim, em 1883 publicou Pinocchio, que alcançou grande importância e é traduzido para vários idiomas.

Coelho (2010) reflete que a personagem Pinocchio foi alvo de muitas interpretações. O encantamento do boneco curioso e teimoso atraiu o espirito infantil. Não por menos, Monteiro Lobato o traduz para o português, em 1933. Simbolicamente, podemos supor que a madeira com que Pinocchio foi esculpido é a humanidade.

É interessante citar o lendário Barão de Münchhausen e suas aventuras, por ter sido uma espécie de guardião da cultura oral. Um contador de histórias que, por sua excentricidade, atraía as pessoas à sua volta, entre elas escritores, poetas e novelistas. Um deles, Karl L. Immermann (1796-1840) publica sua versão, Münchhausen, em 1838. A obra foi destinada ao público adulto por criticar o racionalismo que imperava no século XVIII. Contudo, por apresentar características do fantástico, do excêntrico, pitoresco e cômico, acabou se transformando em literatura infanto-juvenil.

Por sua vez, as Novelísticas de Aventuras significavam uma tendência literária de fundo histórico, dominante no século XIX. Seguiam os passos do Romantismo, caracterizando-se, entre outros, pela busca da renovação social e a redescoberta de valores humanos. A ação do homem no mundo e sua capacidade de autorrealização, ou a crença no poder criador e realizador, são os valores evidenciados.

Destarte, ocorre a novelística de aventura de fundo histórico que tem por representantes Walter Scott, em Ivanhoé; Victor Hugo em O Bom Bispo, incluída na Biblioteca da Infância, além de Eugene Sue em Os Mistérios de Paris. Na novelística de espírito aventureiro e da energia vital destacam-se: Fenimore Cooper, em O último dos Moicanos; Julio Verne, e Mark Twain em As aventuras de Tom Sawyer. E, por fim, da novelística popular derivada das novelas de cavalaria, evidencia-se a literatura de cordel, que circulava no século XIX. De raízes cultas e medievais, integra-se ao romanceiro folclórico do nordeste brasileiro.

Da modalidade Narrativas do Realismo Humanitário destacam-se: Charles Dickens (1812-1870), em David Coperfield; a Condessa de Ségur (1799-1874), em Novos 
Contos de Fada (1856), considerada uma grande escritora de literatura infantojuvenil. E ainda, Louise Mary Alcott (1832-1888), com Mulherzinhas, de 1868, Eduardo de Amicis (1846-1908), em Coração, um livro de leitura para crianças, e, por último, Eleonor H. Porter (1868-1920), em Pollyana.

Pelo próprio sentido indicado em seu título, Narrativas do Realismo Humanitário, trata-se de narrativas que seguem como diretriz o humanismo generoso e sentimental do espírito romântico. E tem por característica principal, assumir a causa das crianças ignoradas e esmagadas pela revolução industrial que começa a absorver a força-trabalho das populações urbanas.

Os valores do Humanismo influenciaram na formação da mentalidade dominante. Contraditoriamente ao progresso material, o nível de pobreza aumentava, vertiginosamente. O progresso econômico aprofundava as desigualdades sociais, ressaltava-se, a partir dessa condição, a busca por justiça social e a luta por direitos do trabalhador, pois a força-trabalho era inferior ao valor-capital. Assim, o que esperar da literatura que emerge dessa condição?

É possível dizer que a literatura, para adultos ou para crianças, produzida à época, visava fomentar a generosidade, a piedade, o afeto e o paternalismo em relação aos fracos e desvalidos. E, dicotomicamente, o incentivo à humildade, obediência, submissão à autoridade, a dedicação ao trabalho, o espírito de sacrifício, o ideal de vida modesta e virtuosa, ou seja, o sistema de valores burgueses-liberais-cristãos. Como citado, David Coperfield é um exemplo que bem caracteriza a situação do fim do século XIX e início do século XX.

Por fim, as Narrativas Jocosas ou Satíricas, que na reflexão de Coelho (2010) tiveram pouca influência entre os pequenos leitores, consistiam em narrativas que mostravam o avesso da vida: o lado burlão, ridículo e mesquinho. Caracteristicamente, são oriundas da tradição luso-brasileira, que apresenta a ancestral história Malasartes e da tradição italiana As Aventuras de Bertoldo. Por sua vez, na área do jocoso aparecem $A$ História de Três Corcovados, de Setúbal; as caricaturas divertidas do alemão W. Bush de nome Juca e Chico.

Recorre-se aqui aos versos de Barros (2013, p. 453-454) como corolário do que foi exposto até agora: "O menino aprendeu a usar as palavras".

Tal qual o menino-poeta, os coletores de histórias fizeram suas "peraltagens". E, prodigiosamente, eternizaram as narrativas infantis. Narrativas plenas de significados e carregadas de propósito. 
Portanto, como assevera Aeurbach (2013), o sujeito na novela é sempre a sociedade, e o seu objeto é a cultura: "uma forma de mundanidade". Isso justifica a natureza da literatura infantil como produto do meio histórico. Dialogando com essa temática, considera Machado (2011):

não podemos nos contentar com a hipótese de que a palavra escrita sirva apenas para transmitir instruções de comportamento ou informações objetivas. O ser humano precisa de muito mais que isso. Necessita ter contato com outra parcela de nosso legado ancestral, aquela que não é constituída somente por informações objetivas e quantificadas: o patrimônio literário (MACHADO, 2011, p. 33).

Como patrimônio da humanidade inteira, a literatura infantil é a fonte em cujas águas se pode beber para compreender o presente e redimensionar o futuro.

\subsection{Da descoberta da infância}

Deste modo, as manifestações literárias produzidas naqueles séculos formadores da literatura ocidental, são impulsionadas por uma intenção didática, moralizante ou educadora. Ao observar essa condição educativa da produção literária, é preciso lembrar que nos séculos XVII e XVIII os modos de representação da criança na literatura e na pintura, demonstram os modelos de criança na sociedade do período.

\footnotetext{
Essa recusa em aceitar na arte, a morfologia infantil é encontrada, aliás, na maioria das civilizações arcaicas. Isso significa que os homens dos séculos $\mathrm{X}$ XI não se detinham diante da imagem da infância, que esta não tinha para eles interesse, nem mesmo realidade. Isso faz pensar também que no domínio da vida real, e não mais apenas no de uma transposição estética, a infância era um período de transição, logo ultrapassado, e cuja lembrança também era logo perdida (ARIÈS, 2012, p. 18).
}

Assim, um dos aspectos levantados por Ariès (2012) no estudo da iconografia da criança, demonstra que ela passa de ser sem significação para a família à membro da mesma. Essa trajetória inclui a visão da criança como um adulto miniaturizado, onde a criança representada não passa de um adulto reduzido. E chega aos três modelos de criança que se desenvolveram a partir do século XIII, mais próximos do sentimento moderno. O primeiro desses modelos é o do anjo representado, que tinha a função de auxiliar nas missas.

A “infância santa" é o segundo modelo de crianças e estava baseado no Menino Jesus ou em Nossa Senhora menina, pois a infância se ligava "ao mistério da maternidade 
da Virgem e ao culto de Maria" (Ariès, p. 20) explica que a figura de Jesus passou por várias representações. Essa representação evoluiu em direção a uma representação "mais realista e mais sentimental”. Ou seja, a presença do menino Jesus em pé ao lado da mãe demonstra um avanço no modo de ver a infância. Ainda tímido, por certo.

Certo é que a figura da infância ainda permanece por muito tempo atrelada a essa imagem, isso é, o sentimento encantador da infância permaneceu limitado ao Menino Jesus. O terceiro modelo é o da criança nua, ou a representação do Menino Jesus nu. Esta imagem de nudez infantil liga-se à alegoria da morte e da alma, a representação da partida da alma. Esta iconografia se manteve até o século XVII. Ressalva-se dessas considerações de Ariès (2010) que a representação da criança sozinha demorou a aparecer. Esse fato, a representação da criança na iconografia religiosa da infância, fez surgir a iconografia leiga nos séculos XV e XVI: "as cenas de gênero e as pinturas anedóticas começaram a substituir as representações estáticas de personagens simbólicas" (ARIÈS, 2012, p. 21).

Dessa maneira, justifica-se o surgimento, na arte, da representação da criança em vários ambientes: em meio às multidões, assistindo aos martírios e milagres, brincando, acompanhado ritos, e, na escola. Então, dois modos de representar a criança se sobressaem: o da criança no meio da multidão, e o da criança em sua graça. Decorrem daí duas situações interessantes, observadas por Ariès (2012): “a tendência de se separar o mundo das crianças do mundo dos adultos, e a ideia que anuncia o sentimento moderno da infância” (ARIÈS, 2012, p. 21).

A flagrada graciosidade da criança é um indício ou um anúncio da representação dela como individualidade, como ser separado do adulto. Esses eventos podem, em princípio, ser lidos como primordiais para a concepção do surgimento da infância como se tem hoje, e como ocorria na era moderna. Embora os modelos de representação da criança sejam vários, ao alcançar o século XV surgiram duas novas maneiras: o retrato e o putto. $\mathrm{O}$ retrato de uma criança real não era visto, sua imagem estava sempre relacionada com a presença de um tutor.

E isso ilustra a pouca importância da infância, encarada como uma fase pela qual a criança deveria passar rapidamente para se tornar adulta, isso quando ela sobrevivia às mortes prematuras. $\mathrm{O}$ fato da pouca importância da infância remetia à constatação da não necessidade em se guardar as lembranças por meio de retratos, tanto da criança que se tornou adulta quanto da que morreu, precocemente.

A indiferença e a insensibilidade perante a infância podem ser lidas como marcas da sociedade da época. A criança era submetida a condições demográficas que pouco 
favoreciam a sua existência ou culminavam em seu fim. Não se atribuía importância à criança enquanto viva, e mesmo após sua morte, não se temia o aparecimento de sua alma.

No entanto, afirma Ariès (2012):

\begin{abstract}
O aparecimento do retrato da criança morta no século XVI marcou, portanto, um momento muito importante na história dos sentimentos. Esse retrato seria inicialmente uma efigie funerária. A criança não seria representada sozinha, inicialmente, e sim sobre o túmulo de seus pais. Mas, ao lado de crianças ainda vivas, eram representadas crianças que já haviam morrido; elas são menores e seguram uma cruz ou uma caveira (ARIËS, 2012, p. 23).
\end{abstract}

Era possível entrever, no fato do gosto novo pelo retrato da criança, de capturar o seu aspecto pictoresco ou gracioso da infância, uma mudança de sensibilidade e expectativa perante esta idade específica da vida? Isso pode provar que a criança começa a romper com o anonimato em que suas parcas condições de sobrevivência a mantinham?

A preocupação com a criança, com sua saúde, sua higiene e vacinação, em especial, se deve ao fato da mudança de sensibilidade, na percepção de que a criança era um ser dotado de alma imortal e de personalidade. A personalidade da criança estava relacionada à possibilidade de cristianização mais profunda.

O putto, por sua vez, a segunda forma de representação desde a Idade Média, é demonstrado pela presença da criança nua, ou o modo de reviver o "Eros helenístico". O tema do Eros nu atravessa os tempos e atinge o século XVII, de modo que "não era possível representar a infância sem evocar-lhe a nudez". O que se percebe, pelos comentários de Ariès (2012, p. 26), é que o Eros nu é uma imagem que se vê na representação do Menino Jesus e outras crianças sagradas. $\mathrm{O}$ gosto da nudez relacionavase ao gosto pela nudez clássica. Talvez, isso representasse o princípio pelo amplo movimento de interesse em favor da infância.

Para se identificar bem essa infância que está sendo desenhada, é importante considerar todas as formas de representação, tais como: a da criança medieval, da criança sagrada ou alegoria da alma, ou do ser angélico. Então, o putto significava uma criança fora do mundo real. Este decorativo da criança nua ultrapassou a Idade Média e atingiu o Renascimento. O gosto coletivo, burguês ou popular, deste tema decorativo, pode ser reencontrado nos álbuns de família. O "Eros nu antigo" continuou a ser usado nos retratos dos séculos XIX e XX, tornando-se convencional.

Unanimemente, entre os autores consultados, considera-se o século XVII o marco para a descoberta da infância. Como exposto pelos estudos de Ariès (2012) até aqui, quando a criança passou a ser o centro na composição do retrato familiar, ou até mesmo quando passou a ser representada sozinha, pode ser entendido que ela passou a existir 
enquanto ser pertencente a um grupo, se não totalmente, mas já significativamente. Os sinais de seu desenvolvimento se deram nos fins do século XVI e durante o século XVII (ARIÈS, 2012, p. 28).

Há um conjunto de fatores que devem ser lembrados para o entendimento do processo de surgimento da infância, do modo como é concebida ainda hoje. Um desses fatores é o desenvolvimento do sentimento de infância e de família; o segundo é o fato de que não é possível pensar em infância, naquele período, sem pensar no processo de enclausuramento. O modo como a criança passou a ser tratada pela família, os cuidados que ela passou a receber, a necessidade de educação, entre outros, atrela-se ao modo de necessidade de vida burguesa.

Nessa relação encontra-se também a presença do livro e da formação de um público específico de leitor, através da escolarização. Se a infância tornava o repositório dos costumes abandonados pelos adultos, nas concepções de Ariès (2012, p. 43), ela herda seus hábitos, costumes, jogos, histórias, contos e brincadeiras. Pode-se entender, com a declaração de Ariès (2012), que aspectos culturais são reaproveitados para a infância quando deixam de ser importantes para os adultos, quando se tornam "simples" demais ou ultrapassados.

A título de exemplificação, Ariès (2012) relata que o arco deixou de ser um objeto de adultos e passou a ser manuseado pelas crianças cada vez menores, no século

XVII. Paralelo a esse exemplo, afirma o autor que "histórias eram contadas a Luís XIII, os contos de Melusina, que eram contos de fadas. Mas, nessa época, essas histórias se destinavam também aos adultos" (ARIÈS, 2012, p. 70).

Nesse entendimento, o autor explana:

\begin{abstract}
Contudo, na segunda metade do século, começou-se a achar esses contos muito simples. Ao mesmo tempo, surgiu por eles um novo tipo de interesse, que tendia a transformar em um gênero literário da moda as recitações orais tradicionais e ingênuas. Esse interesse manifestou-se de duas maneiras: nas publicações reservadas às crianças, ao menos em princípio, com os contos de Perrault, que ainda revelavam uma certa vergonha em admitir o gosto pelos velhos contos, e nas publicações mais sérias, destinadas aos adultos, e das quais se excluíam as crianças e o povo (ARIÈS, 2012, p. 71).
\end{abstract}

A existência de gêneros diferentes para públicos diferentes, como demonstra o trecho, requer um olhar mais sofisticado, uma pesquisa mais profunda. No entanto, das considerações de Ariès (2012) evidencia-se o fato de que a produção oral persistia nos tempos e espaços, e carecia de registro. Então, a necessidade de se fixar a tradição através da escrita, em livros, é um acontecimento que muda o modo de consumo cultural, através da busca por leitores, nos séculos XVII e XVIII. 
Para ilustrar, ocorreu na época a edição de contos destinados ao público rural alfabetizado, a chamada Biblioteca Azul ou Contos Azuis por ser impressas em papel na cor azul. Consistia na edição de textos, na íntegra, das velhas histórias orais. E, reforçando o que já foi citado, o Ariès (2012, p. 72) relembra a importância dos contadores de histórias, que eram ocasionais ou profissionais e agiam como os velhos declamadores e cantores de jograis.

Ao que deixa transparecer, Ariès (2012, p. 73) preocupa-se em descrever o modo como os contos, escritos ou orais, vão se desgastando, no sentido de perder o interesse.

Ele relata que os "contos azuis", por exemplo, deixaram de ser interessantes para o público rural, com o uso do jornal. Então, esses "contos azuis" e os orais passaram a ter nas crianças um público mais cativo.

Ao pensar na produção literária para a criança do século XVII e XVIII, toma-se o conceito de "civilidade" estudado por Chartier (2003, p. 46), que de algum modo dialoga com o estudo de Ariés (2012). Isto é, a sociedade burguesa, ao que parece, precisava criar suas tradições, seus costumes, para se estabelecer culturalmente. Seguindo esse mote, as instituições escola e família, no campo privado, tornar-se-iam o esteio para o florescimento desse cidadão honesto, conveniente e polido.

Relaciona-se aqui, deliberadamente, a noção do público por Ariès (2012), à noção dessas práticas sociais que se baseavam nas ideias de moral, virtude e honra, para também compreender que o desenvolvimento do comportamento civil esperado, dependia dos instrumentos civilizatórios possíveis. Nesse empreendimento, ressaltavase o processo de enclausuramento ou escolarização, que inclui a produção literária como meio para se atingir o fim da educação burguesa.

Como, então, compreender o processo de formação da concepção de infância? Por que relacioná-la à questão da escolarização?

As respostas para cada uma dessas questões podem ser complexas. No entanto, é possível observar, pelo olhar dos estudos consultados, que a infância é um produto do projeto de construção da civilidade aos moldes da burguesia. Isso inclui um modelo de educação que prevê o ensino de normas sociais que visem formar uma mentalidade e consciência de mundo. Para tal, era precisa a redefinição de vários conceitos, entre eles o de infância e de escola.

O papel da escola estava voltado para a formação da tradição burguesa que se queria constituir. Isso implicava a fomentação de projetos educacionais influenciados pelo Racionalismo ou as conquistas científicas e tecnológicas do século XVIII e XIX. Isso 
implica também a importância da doutrina empirista de John Locke para a qual a origem do conhecimento é a experiência.

No entanto, deve-se avaliar a presença marcante da doutrina naturalista de J. J. Rousseau (1712-1778) baseada em ideias religiosas em que a bondade natural do homem é corrompida pelos males da civilização.

Politicamente, a transição da sociedade de modelo monárquico-absoluto para o monárquico-liberal é observada também no campo educacional. Isto é, do sistema clássico-humanista, religioso e medieval, para o sistema liberal-humanista, com base científica.

Desse modo, pode-se observar que

a transformação mais evidente na história mundial da infância envolve a passagem das sociedades agrícolas para industriais (e a imitação dos padrões industriais, como escolaridade massiva, mesmo nas sociedades que ainda não completaram seu processo de industrialização). O processo fundamental da infância foi redefinido e disso resultou uma série de consequências instigantes (STEARNS, 2006, p. 19).

Embora esta importante passagem de Stearns (2006) indique um momento avançado na discussão em torno das experiências da infância, que é a redefinição e suas implicações na contemporaneidade, interessa pensar que sua constituição deu-se a partir de vários eventos sociais. Ou seja, a história mundial permite enxergar, em seu quadro geral, que ao surgimento da infância imbricam-se processos religiosos, econômicos, políticos e culturais. A infância é uma experiência plural e, por isso, deve-se pensar em infâncias como modo de entendimento da experiência humana.

Para Stearns (2006, p. 80), os motivos levantados por Ariès que demonstram que a preocupação em torno da infância somente ocorreu na modernidade devem ser questionados. No entanto, os revisionistas dos estudos de Ariès (2012) estão de acordo e admitem que, entre os períodos pré-moderno e moderno, ocorreram várias mudanças nas ideias, práticas e contextos em torno da infância ocidental, muito embora eles discordem que anteriormente não houve um reconhecimento da infância e sinais de afeição pelas crianças.

Como referido anteriormente, Rousseau contribuiu para o processo de individualização das crianças, o que incluía o modo afetivo familiar no trato das mesmas e os métodos de escolaridade que primassem em nutrir-lhes a centelha criativa.

Assim, ao pensar num modelo moderno ocidental de infância, que emerge entre os séculos XVII e XVIII, distante do modelo das sociedades agrícolas, observa Stearns (2006, p.21) que há três mudanças primordiais: a primeira é a captação da criança para a 
escola e não mais para o trabalho; a segunda mudança está na diminuição das famílias e a terceira transição fundamental do modelo envolveu a redução das taxas de mortalidade infantil. Essas três vertentes são primordiais para se entender as mudanças na concepção de criança e de infância. Todavia, pensar no elemento "escola" em vez de trabalho, é pensar também no tipo de literatura que poderia ser útil ao processo de desenvolvimento educacional.

Mediante o exposto a respeito do modelo moderno de infância, é possível observar que sua consolidação vai ocorrendo paulatinamente entre o Romantismo e o Realismo. A partir do século XIX verifica-se a confluência e o amálgama dos valores herdados da aristocracia da Era Clássica e dos novos valores forjados pelo individualismo românticoplebeu. A esse respeito, pode se refletir com Coelho (2010)

É que a criança é descoberta como um ser que precisava de cuidados específicos para sua formação humanística, cívica, espiritual, ética e intelectual. E os novos conceitos de vida, educação e cultura abrem o caminho para os novos e tateantes procedimentos nas áreas pedagógicas e literárias. Pode-se dizer que é nesse momento que a criança entra como um valor a ser levado em consideração no processo social e no contexto humano (COELHO, 2010, p.18).

Assim, literatura infantil e infância nascem imbricadas. 
II

Da criação lobatiana às perspectivas contemporâneas da literatura infantil brasileira 


\section{1. Divisor das águas}

Ao gosto da pedagogia maternal ${ }^{7}$, no final do século XIX, surgiu uma literatura infantil sustentada pela frase: O leite é o alimento do berço; o livro, o alimento da escola. Esta frase ilustra o projeto pedagógico do momento político brasileiro situado após 1822, marcado por reformas na educação em que são empreendidas várias medidas de estruturação da educação nacional com orientação das diretrizes iluministas.

É possível traçar uma linha evolutiva da produção literária no Brasil, que se vinculou ao projeto de estruturação da educação nacional. As publicações tiveram início em 1881 com O Livro do Povo, de Antônio Marques Rodrigues. E, para citar outros exemplos: Contos Infantis, de Júlia Lopes de Almeida, de 1886, e Coisas Brasileiras, de Romão Puiggari, de 1893, que foge ao recorrente esquema didático das obras.

Além de várias publicações de Arnaldo de Oliveira Barreto, importante nome na produção literário-pedagógica brasileira e pioneiro na área editorial brasileira, deve-se citar aqui a obra Saudade (1919), de Tales de Andrade, que inaugurou um estilo de novela e abriu o caminho por onde trilhou a literatura didática: o ruralismo, a natureza natural. Tendência geral na literatura pós-guerra cuja visão era a da valorização da paz e da justiça social. Este período de fim de século precedeu a obra lobatiana.

Assim, em 1921, foi publicada a obra A Menina do Narizinho Arrebitado, que marcou a estreia de Lobato, que soube dosar os ingredientes rurais aos herdados pela tradição novelística universal, por ele dominada.

Embora exista o cuidado ao analisar, na contemporaneidade, alguns aspectos importantes da obra de Lobato em termos da construção da imagem da pessoa negra na sociedade, é inegável o seu papel na renovação e constituição da literatura infantil e juvenil brasileira em sua constituição. Vários autores consideram-no o divisor das águas que separa o Brasil de ontem e o Brasil de hoje. Uma das atividades importantes de Lobato foi se ocupar com a busca pelo nacional, pela brasilidade na literatura para adultos e crianças, valorizando figuras do folclore nacional. Além dos aspectos políticos e econômicos, sua preocupação também alcançou a questão da produção de livros para as crianças brasileiras. Segundo Coelho (2010, p. 234), ele questiona sobre "o que é que nossas crianças podem ler”?

\footnotetext{
${ }^{7}$ Nelly Novaes Coelho elucida que essa produção literária tem por principal figura o poeta Romântico João de Deus que, em 1876, publica a Cartilha Maternal. Outros nomes importantes são: Guerra Junqueiro por Contos para Infância e Antero de Quental, por Tesouro Poético da Infância.
} 
Com essa inquietação, Lobato empreendeu uma escrita diferenciada, uma produção literária controvertida e vasta. O que incluía a produção de originais, traduções e adaptações. Por sua postura diante das coisas do mundo, Lobato sempre foi uma figura controversa. Em sua obra, ele substitui o sentimentalismo pela irreverencia, pelo humor e pela ironia. Evidencia-se de sua obra o caráter lúdico, evitando situações dramáticas comuns nas obras para crianças.

Em sua obra Sítio do Picapau Amarelo, Lobato criou uma situação familiar singular. Tudo se passa longe do olhar materno ou paterno, num ambiente diferente da casa familiar, um sítio que convida a todo tipo de aventuras. Onde quem tem as rédeas é uma avó, tão mediadora, quanto afetuosa. E ainda, Emília, a representação da menina malcriada.

Assim, a literatura infantil brasileira ganhou impulso após a presença lobatiana. Sua influência na movimentação de livros foi sensível. O que implica que a literatura infantil brasileira seguiu uma vertente educacional antes e após Lobato. Isso se dá também na era Vargas, onde se verificou a intensificação da luta pela reestruturação da ideia de nação, que incluía a educação e a literatura infantil. O surgimento da Biblioteca Infantil Monteiro Lobato, em São Paulo, em 1936, intensificou o tom da intencionalidade pedagógica da literatura.

É importante considerar que a produção literária de 1930 foi marcada pelo antagonismo entre Realismo e Fantasia. Baseada na necessidade de se conhecer a realidade brasileira, no lugar da fantasia deve-se incluir a realidade, a verdade. Esse aspecto influenciou, entre outros, a expansão das histórias em quadrinhos. Verificou-se, portanto, o conservador movimento de caça às bruxas da fantasia ou a desvalorização de personagens fantasiosos. No entanto, a fantasia foi retomada na produção literária dos $\operatorname{anos} 1950$.

Não se pode discutir literatura infantil brasileira em seus primórdios, sem refletir sobre a obra lobatiana, embora, na atualidade, haja questões discutíveis de suas escolhas políticas, principalmente o modo eugênico como tratou as questões étnicas em suas narrativas. Assim como a sua obra incentivou a construção negativa da pessoa negra no imaginário brasileiro. Isso é fato. No entanto, a construção estética que ele empreendeu rompe com o modo de leitura puramente didática e envolve o leitor de modo prazeroso; assim, de algum modo, apreciar suas estórias era o mesmo que manipular brinquedos. 


\title{
2. O segundo divisor das águas: A década de 1960
}

Ao pensar a importância do livro infantil para construir o sentimento de identidade nacional, ainda necessário, é possível indagar junto à Chartier (2009, p. 7): “será que os livros fazem revoluções"? Para responder, o autor baseia-se nas reflexões de Tocqueville, e responde que os homens de letras não apenas conferiram suas ideias revolucionarias para a nação francesa; eles moldaram o temperamento nacional e uma visão de vida.

E Chartier (2009) acrescenta:

\begin{abstract}
Assim, esses três autores ${ }^{8}$, cada um à sua maneira, entenderam a formação da opinião na França pré-revolucionária como um processo de internalização, por parte de um número cada vez maior de leitores, das maneiras de pensar propostas pelos textos filosóficos. Carregadas pela palavra impressa, as novas ideias conquistaram a mente das pessoas, moldando a sua forma de ser e propiciando questionamentos. Se os franceses do final do século XVIII moldaram a Revolução foi porque haviam sido, por sua vez, moldados pelos livros (CHARTIER, 2009, p. 115).
\end{abstract}

Essa reflexão de Chartier (2009) dialoga com os eventos que tornaram os anos de 1960, no Brasil, anos de grande expressão cultural. A explosão da música popular brasileira é um bom exemplo desse momento ímpar. Marcada pelos grandes festivais, pelo surgimento de movimentos da bossa nova e de outros, a música nacional explode tanto em criatividade quanto politicamente, ao tornar-se um espaço crítico da ordem vigente no país, de cerceamento da liberdade individual. Como afirma Coelho (2010, 255), “A Música Popular Brasileira vai-se transformando em um espaço intelectual e critico que, de certa forma, no passado era ocupado pela Literatura".

Deve-se, antes, lembrar que no campo educacional, com o processo de democratização do ensino foi, enfim, votada a LDB no 4.024, de 20 de junho de 1961, cujos trâmites caducavam desde 1948. A lei previa a extensão da escolaridade para oito anos, no intuito de ampliar o acesso para as camadas mais pobres da população, e a descentralização dos currículos. É evidente, os índices alcançados são ínfimos, precários, pois nenhuma revolução cultural se dá instantaneamente.

A leitura literária, ao que indica, representou o ponto de apoio para o desenvolvimento das múltiplas atividades. Dessa atitude decorre a demanda de obras literárias. Assim, escritores e escritoras que vinham de uma experiência de literatura para adultos, embrenharam-se na produção de textos para o desenvolvimento da leitura nas escolas. "Não descuidando do estilo que funde o real e o imaginário, multiplicam-se

\footnotetext{
${ }^{8}$ Chartier se refere às contribuições dos estudos de Alexis de Tocqueville, Hippolyte Taine e Daniel Mornet.
} 
traduções e adaptações juvenis, bem como o surgimento dos clássicos da literatura infantil” (COELHO, 2010, p. 258).

Curiosas são as palavras de Ana Maria Machado (2011):

\begin{abstract}
Depois que Lobato morreu, em 1948, houve um hiato, uma espécie de terra de ninguém nessa área. Nenhum escritor ousava tentar substituir um homem tão influente. Foi como se os livros infantis no Brasil entrassem então num longo sono, um período de hibernação que durou vinte anos. Quando houve o golpe militar em 1964, a maioria dos livros que se publicavam para crianças no país eram meio bobos, mais na área da pedagogia do que da literatura, e tentavam dar lições - salvo uma ou outra exceção (MACHADO, 2011, p. 110).
\end{abstract}

A manifestação criadora na citação de Coelho (2010, p. 259) mostra que a ditadura militar agia de modo mascarado no Brasil, "permitindo" a produção cultural dos escritores. No entanto, dialogando com Machado, apesar da intensa perseguição, greves e endurecimento militar, no final da década de 1960, vários autores insurgiram-se com publicações de obras significativas no campo da literatura infantil e juvenil na Revista Recreio. Dentre eles estão Ziraldo, Lígia Bojunga, Ruth Rocha, Joel Rufino e Ana Maria Machado.

Esses intelectuais e artistas, oriundos de áreas diversas, queriam dizer algo diferente do que era estabelecido. A escrita simbólica, humorística e poética foi o modo estabelecido para esta comunicação da realidade. A escrita peculiar, que despistava a censura militar, acabou por interessar às crianças. Então, as manifestações culturais e políticas tornaram esse período da vida brasileira, um espaço sui generis. E tiveram na música popular e na literatura infantil as ferramentas basilares.

Como seria o produto dessa literatura infantil? Qual a sua finalidade: pedagógica ou literária? Segundo Machado (2011, p. 111), a temática desenvolvida não girava apenas em torno de simples fábulas políticas, mas eram diversificadas e envolviam, obviamente, a "luta pela liberdade e a denúncia de toda a forma de dominação". Ao desafiar a ordem estipulada, as histórias faziam surgir, em seu bojo, a desigualdade social e econômica, bem como a realidade de grupos marginalizados.

\title{
2. 3. Década de 1970 e 1980: o boom na literatura infantil brasileira
}

A função da literatura infantil, muito além da formação das crianças e jovens, atrela-se ao conjunto complexo das contingências descritas. E ainda, agregam-se os eventos iniciados à década de 1970, conduzindo a uma visão mais circunstanciada da questão. Embora o seu caráter didático internalizado, pueril e moralizante, é preciso 
observar as diversas fases pelas quais tal produção literária caminhou, como afirma Lourenço Filho ${ }^{9}$ :

\begin{abstract}
Buscando responder a perguntas de seu tempo, Arroyo produz uma versão da história da literatura infantil brasileira. Essa história o autor a caracteriza como um processo evolutivo complexo e diversificado 'em face das numerosas áreas culturais brasileiras e prevalência transregional dos elementos característicos da educação'. E, nesse processo evolutivo, identifica fases, de acordo com sua sucessão (complexamente linear) no tempo: a literatura oral, a literatura escolar, a imprensa escolar e infantil e, por fim, a "maturidade de nossa literatura infantil", a partir da publicação, em 1921, de Narizinho Arrebitado, de Monteiro Lobato (ARROYO, 2010, p. 16).
\end{abstract}

Então, ao caráter ambíguo que envolve a literatura infantil no que diz respeito a sua constituição, literária ou didática, tem maior peso a vertente que parte em busca do valor no campo estético. De qualquer modo, definir os caminhos para se atingir tal literariedade é necessário a superação do didatismo. Para tal, é preciso reconhecer as potencialidades da literatura infantil enquanto objeto de arte e fazer a leitura de cada momento histórico.

Este olhar linear, horizontal e vertical sobre a literatura infantil engloba, também, os eventos que deflagraram processos de mudança no mercado editorial a partir da década de 1960. Graças às discussões acadêmicas de vulto ocorridas, bem como a inclusão da disciplina Literatura Infantil nos cursos de Magistério em nível profissionalizante, o projeto governamental de democratização, acesso e permanência na escola, incluindo a redução dos índices de alfabetização, a produção literária infantil alcançou outros patamares mais sensíveis.

Os movimentos sociais impulsionaram a época. Entre eles, o movimento de mulheres e o movimento negro representaram chaves que abriram caminhos para o surgimento de uma literatura engajada. A produção de literatura infantil foi incentivada pela ação governamental de promoção de leitura, como ferramenta para a diminuição dos índices de analfabetismo. Essas manifestações em prol da leitura infantil são, para Cademartori (1990, p. 8) tributárias da implantação de programas de alfabetização, que, de algum modo, trazem a criança para o centro das discussões.

Esse boom representou um processo vital na produção, editoração, mercado e circulação do livro infantil no Brasil, motivado pela escrita literária subversiva produzida em larga escala. De algum modo, significou a ampliação de um espaço cultural que venceu as iniciativas esparsas da década de 1960, altamente influenciada pelo caráter

\footnotetext{
${ }^{9}$ Palavras de Lourenço Filho na apresentação à terceira edição de Literatura infantil brasileira, de Leonardo Arroyo.
} 
didático. Ao redor da ambiguidade, pedagógica ou literária, da literatura infantil brasileira desenvolve-se um campo de conhecimento específico e interdisciplinar.

Assim, aliada à publicação de obras literárias, foram publicados também estudos de vários pesquisadores da área, como: Nelly Novaes Coelho, Ligia Cadermatori, Edmir Perroti, Fúlvia Rosemberg, Marisa Lajolo, Regina Zilberman, para citar alguns. A literatura infantil se abre como campo literário em que, tanto em gênero quanto em temáticas, pode-se observar grande amplitude. Como, pois, conceber esse campo de estudo?

Como campo de ação cultural, a literatura infantil na contemporaneidade não se descuida de refletir o momento social e político com uma produção que se ocupa em romper com qualquer espaço dominante. Aos moldes dos movimentos sociais, esse gênero segue reavivando discussões deliberadamente esquecidas, no tocante às questões de gênero e de etnia. Então, se na década de 1970 ela dá um impulso que redimensiona a sua trajetória, nas décadas seguintes, a literatura infantil brasileira consolida-se como um campo de produção cultural de grande vulto.

Muito embora esse avanço tenha um lastro pedagógico e institucional relevantes, não dá para encolher sua importância perante os processos de mudança do modo de estar no mundo e como desconstruir imbricados processos de desigualdade e de exclusão, através da leitura. Surge, então, a pergunta: é possível pensar na literatura infantil como ferramenta promotora de mudança?

Não é possível, ainda, afirmar que a literatura infantil atingiu a tal maturidade mencionada anteriormente por Lourenço Filho, principalmente por não romper com os processos do didatismo. Embora seu fortalecimento tenha se dado por ter o governo como seu mecenas atualizado, não implica dizer que o seu acesso resulta em aumento na formação de verdadeiros leitores. Porém, valendo-se da prerrogativa de ser ferramenta importante para a promoção da mudança na contemporaneidade, a literatura infantil estabelece diálogo com o projeto de reconstrução da identidade nacional e do rompimento com processos de racismo.

É impossível determinar que o substantivo "literatura" supere o adjetivo "infantil". Então, pensar a literatura infantil na contemporaneidade é seguir uma trajetória linear na perspectiva histórica que a constitui e com a qual não se pode romper totalmente, bem como, traçar um alinhamento verticalizado no sentido de inserir outros elementos que tornam a escrita para crianças e jovens, não apenas um meio para torná-los sujeitos moralmente melhores (embora seu caráter pedagógico internalizado), mas para atraí-los 
para dentro do espaço de identidade e de desconstrução de processos de racismo eternizados, enraizados na realidade brasileira.

\section{4. A literatura infantil do século XXI}

Hoje, é perceptível o caráter múltiplo, interdisciplinar e verticalizado da literatura infantil. Embora esta postura atual não descaracterize a constituição pedagógica da literatura infantil, ainda, é possível afirmar que no bojo do mercado editorial está presente a diversidade de intenções literárias. É essa diversidade que promove uma discussão mais profícua em torno da produção literária, e suas relações com o momento sócio-histórico.

Há a possibilidade de diálogo entre este alargamento de visão, como proposta da produção literária infantil contemporânea, com o que afirma Mignolo (2003, p. 92) em torno do rompimento com projetos hegemônicos, que através do ocidentalismo ou o imaginário dominante do sistema colonial moderno, tornam-se um poderoso veículo de subalternização.

Mignolo (2003) aponta que o conhecimento ocidental tem um proprietário e local determinados, historicamente centralizado. E, nesse sentido, o pensamento ocidental europeu é, naturalmente, aceito pelo outro que é o colonizado, o subalterno: o Oriente, a América Latina. Daí a necessidade de subverter os limites fixados de conhecimento, naturalizado e canônico. O território do conhecimento deve ser redimensionado e seus projetos globais de imposição de conhecimento, revistos. Em seu lugar, um projeto local deve ser erguido como proposta de outro pensamento, desnaturalizando e desconstruindo cânones.

Urge a instituição de um outro pensamento liminar que revolva as estruturas coloniais modernas em modernidades coloniais que, entre outros caminhos, indique uma nova razão pós-ocidental, pautada na descolonização epistêmica. E, visto pelo olhar do subalternizado, o pensamento liminar é produzido na intersecção dos colonialismos modernos e o conhecimento produzido na perspectiva das modernidades coloniais.

Ao que parece, a descolonização envolve a reorganização de projetos localizados. A proposta, consideravelmente atraente, de Mignolo (2003, p. 108) é de redefinição da geopolítica do conhecimento. Isso implica que há uma travessia do entendimento em torno do global em direção ao local. Ou talvez o contrário. Observa-se que o conhecimento é caminhante e se desloca. E, de posse do colonizado, muitas vezes pode ser silenciado. 
Após tais reflexões em torno do pensamento de Mignolo, é possível reconhecer na produção da literatura infantil brasileira na contemporaneidade, a influência dessa postura de ruptura com paradigmas e a busca por novas temáticas, bem como a presença de novas linguagens e de espaços de voz. E isso inclui a discussão de novos autores que têm procurado contribuir com a reincidência de processos históricos de discriminação, tornando possível provocar o alargamento das margens, dos espaços discursivos propostos por Mignolo (2003, p. 123).

Estas considerações são também promotoras da verticalização que se inscreve com a presença de novos discursos na literatura infantil contemporânea, e demonstram as multifaces desse gênero literário. Além de todos os eventos que contribuíram para sua mudança, no âmbito nacional, soma-se o aparato legal que instituiu a redução da desigualdade racial, proposta pela implantação da Lei 10.639 de 2003, e que estabeleceu a obrigatoriedade do estudo da história geral da África.

Ou seja, a temática voltada para a discussão da etnia aquece o mercado editorial, contribuindo para a promoção de atividades de letramento na escola. Deste modo, através de programas de circulação de livros como o Programa Nacional Biblioteca da EscolaPNBE, obras que demonstram o protagonismo negro e a desconstrução do imaginário da escravidão, surgem como proposta de recondução de discursos de racismo e o rompimento com o falseamento da democracia racial à brasileira. Passaram a circular obras que trazem a discussão das culturas africanas para, entre outros, colaborar na construção das identidades africanas usurpadas do cotidiano do brasileiro.

Assim posto, constata-se que a literatura infantil brasileira passa por um momento diferenciado em relação aos seus propósitos de "formação e diversão", ao alargar suas margens e se abrir para os imperativos do momento social, em que tais posturas auxiliam na definição desse campo de produção cultural.

Ao que parece, o leque de possibilidades da literatura infantil vai se estendendo. Nesse sentido, Coelho (2000, p. 137) assegura que novos elementos são recorrentes nos contos infantis, tais como: a problematização da linguagem, questionamentos sobre a nova ótica para pensar as relações eu-mundo, a fusão de linguagens engendradas pelos multimeios de comunicação. Estas considerações da autora não somente atualizam temáticas, mas encerram ponderações importantes.

Essas sugestões para o agenciamento da literatura infantil interligam-se às contribuições como as de Pierre Bourdieu (1992) que, por sua vez, desenvolve o conceito de campo cultural de modo interdisciplinar: estético, filosófico, literário e intelectual. Campo que se constitui por romper com a estrutura da hegemonia da produção cultural, de 
caráter incessante e continuo, cujo valor rompe com o fetiche do autor ontológico e consolida-se no campo histórico (BOURDIEU, 1992, p. 235). Propõe-se, assim, que a apreensão do mundo é o verdadeiro assunto da obra de arte, cujo habitus é o princípio de estruturação social da existência temporal, e das antecipações de onde se constrói o sentido do mundo.

Em relação ao campo de produção, emerge o artista que rompe com a visão de criador incriado ${ }^{10}$ do século XIX ou o artista socialmente instituído como criador. O campo de produção cultural é fissurado e, por tal motivo, favorece o seu preenchimento. O reconhecimento desses espaços pode incluir a discussão em torno do "pertencimento social, a autonomia e valor do artista” (BOURDIEU, 1992, p. 325-326).

É complexo definir a literatura infantil como campo de produção estética, devido a sua ambígua constituição. No entanto, quando de cruzam as discussões entre o pensamento liminar e o estabelecimento de campo, surge um ponto de tensão quando o olhar se volta para a produção de literatura infantil contemporânea. Observar-lhe as intenções políticas não exclui as vertentes estéticas. Na verdade, ambas podem trilhar caminhos paralelos.

As fissuras lembradas por Bourdieu (1992) podem ser lidas como as temáticas desenvolvidas na literatura infantil. Nesse bojo, as discussões de gênero e de etnia na linguagem literária ensejam um protagonismo paradigmático: a presença da menina negra nas narrativas infantis. Perceber essa presença na produção literária recondiciona o olhar; o ponto de vista se desloca: a voz do subalterno pode ser ouvida.

A tensão, resultante do pensamento liminar e da definição de campo estético, envolve tanto a presença do protagonismo da menina negra, quanto a escrita negra que contribui na redistribuição da geopolítica do conhecimento. Em um processo de descolonização, o rompimento com meios de manutenção da imagem negativa da pessoa negra se estabelece como perspectiva de leitura desse sistema moderno, com discursos que operam a partir e entre as diversas histórias locais.

Desse modo, lembrar a questão do preenchimento das fissuras como espaços discursivos na modernidade é dar visibilidade a grupos marginalizados. Ao se avaliar no imaginário brasileiro as questões de visibilidade da mulher negra, percebe-se que para se construir o processo de identidade da pessoa negra, há de se começar pela infância negra.

\footnotetext{
${ }^{10}$ Para Bourdieu (1992) o criador incriado parte da conceituação ideológica do século XIX, que na visão essencialista, definia o valor da obra pelo valor do artista.
} 


\section{5. Identidade, visibilidade e representação}

Discutir a identidade da menina negra constitui-se uma estratégia, no mínimo, inusitada. Tanto por se tratar de momento controverso da vida humana - a infância, quanto por trazer ao centro do círculo a menina negra. O que evidencia uma silenciada tríade discursiva: a infância, a menina e a negritude.

Os caminhos para estabelecimento da visibilidade da pessoa negra seguem diversificadas vertentes. Não devemos negligenciar o impacto das Orientações e Ações para a Educação das Relações Étnico-Raciais. No âmbito escolar a legislação prevê, a partir da sanção da Lei $n^{\circ}$ 9.394/96 e a Lei no 10.639/2003, o debate da educação a serviço da diversidade, como desafio para a estruturação de uma política nacional de educação calcada em práticas antidiscriminatórias e antirracistas, bem como, de "reparação humanitária do povo negro brasileiro" (MEC, 2010, p. 19).

Entre as décadas de 1970 e 1990, o movimento das mulheres negras lutou pela oportunização de creches e de pré-escolas, bem como, criticou o modelo de escola que desconsiderava o patrimônio histórico-cultural da pessoa negra. Essa negligência evidenciou os processos de racismo que, acima de tudo, deflagraram a evasão e a repetência escolares de crianças negras.

Por sua vez, políticas afirmativas procuram reverter o processo que contribuiu para a perpetuação do imaginário, onde a presença da pessoa negra relaciona-se à situação de servidão perante a escravidão, além de reconduzir os passos históricos do retrocesso. Da escola, como espaço democrático, espera-se o rompimento com o silenciamento em torno da manutenção da supremacia branca, o desenvolvimento de práticas que vivenciem e valorizem o pertencimento do negro no cotidiano escolar. Este é um dado social relevante para a compreensão da veiculação de livros literários.

Concomitantemente, o mito da democracia racial no Brasil propõe uma forjada igualdade de oportunidades entre classes sociais diferentes, entre negros e brancos, entre homens e mulheres e entre meninos e meninas. $\mathrm{O}$ ato de mascarar a realidade brasileira é um processo que envolve medidas essencialistas, que retêm em seu bojo, discursos hegemônicos que entorpecem a visão e a consciência em torno do racismo, por exemplo.

Por estas razões, o processo de construção da identidade negra percorre caminhos complexos, pois, ao reivindicar sua identidade, a pessoa negra propõe-se à busca por pertencimento. Questionar a identidade requer perceber as sutilezas de ser o Outro. Entretanto, o Outro não inferiorizado. 
Como entender os processos de identificação da menina negra na contemporaneidade? É possível que a solução para este questionamento caminhe para o entendimento de que a menina negra é vista como "Outro". Mas o outro de que "Mesmo"? ${ }^{11}$ Talvez não seja possível criar mais uma categoria especial de análise de gênero para situar as discussões sobre a menina negra. Então, é possível incluí-la na categoria mulher negra?

Para encaminhar estas e outras questões, deve-se pensar na menina negra como categoria diferenciada? A dificuldade se desenha por não se incluir totalmente na categoria de meninas, por se estar distante da faixa etária das mulheres negras, por se opor em gênero aos meninos negros. Será possível tratá-la por sujeito menina negra, situado no lugar especial que é a infância? No entanto, como pessoa negra, a menina negra é impactada por todas as questões que envolvem a mulher negra, tais como identidade e visibilidade.

Sabe-se que identidade é um conceito relacional. Nesse sentido, para a delimitação da categoria sujeito menina negra, faz-se mister agregar à discussão a relação com o outro. Por assim dizer, a identidade não é um conceito que caminha singular. Ele engloba a questão, já apontada, de ser igual, ser diferente. No entendimento de Woodward (2014, p. 9), "a identidade é marcada pela diferença; a diferença é sustentada pela exclusão". Em que o sujeito menina negra é igual, como ela é diferente? Essa reflexão pode implicar, também, pertencer ou negar. Desse modo, a busca por identidade, de algum modo, envolve compreender os processos de diferença e igualdade, pertencimento e negação.

Pelos estudos pós-coloniais analisados aqui, a definição de identidade ocorre no plural. Daí o uso de “identidades” para abarcar as várias situações que esse conceito encerra. Nesse sentido, para Woodward (2014, p. 13), as várias conceitualizações de identidades podem significar o modo essencialista pelo qual se reivindica o pertencimento a determinado grupo identitário. É o caso de alguns grupos étnicos que reivindicam a raça baseada na natureza, tomada como verdade imutável.

É possível observar que a construção do conceito de identidade vem sendo baseada, não apenas, em binarismos, onde o que é tradicional se opõe ao moderno, o outro ao mesmo, o ocidentalismo ao resto do mundo como periferia, centro e margens. Neste aspecto, o conceito de identidade é relacional. E, no pensamento de Hall (2003, p. 31), as relações vão se complexificando, no sentido de que "a distinção de nossa cultura é

\footnotetext{
${ }^{11}$ Grifos meus.
} 
manifestamente o resultado do maior entrelaçamento e fusão, na fornalha da sociedade colonial, de diferentes elementos culturais africanos, asiáticos e europeus”.

Neste comenos, conceber tal campo de ação é perceber outros patamares discursivos que, para Hall (2003, p. 53) atingem a questão do "multiculturalismo plural" como estratégias políticas que organizam ou administram conceitos como raça, identidade e diáspora. Em termos culturais, o multiculturalismo plural avaliza diferenças grupais.

Então, a delimitação da identidade da menina negra parece inserir-se nesses aspectos estudados. Tanto socialmente, quanto culturalmente, o gênero feminino, por exemplo, foi mantido como "fora" dos espaços dominados pelo masculino. No entanto, a questão não se justifica, na atualidade, apenas nesta marcação de desvalorização em relação ao masculino. O jogo de identidade, do feminino em relação ao masculino, se complexifica ao se incluir a questão da etnia.

Para o melhor entendimento da questão identitária, Hall (2003, p. 60) propôs que o conceito "raça" seja uma categoria política e social em que surge a prática discursiva do racismo. E, decorrem daí mecanismos de fechamento discursivo em situações cotidianas devido ao tipo de leitura que possa ser feita dos "significantes corporais visíveis". Por sua vez, o termo "etnia" ou "etnicidade", que tem por fundamento aspectos culturais e religiosos, implica em oposição ao conceito "raça". Principalmente porque à etnicidade são mais pertinentes características relativamente fixas.

Por sua vez, os conceitos "racismo" e "etnicidade" demonstram que o modo de olhar o outro considerado diferente varia em intensidade de abertura no sentido de fugir ao capricho do essencialismo ou do que é tido como tradicionalmente fechado, ou ao que é verdade absoluta, ou culturalmente melhor. Etnicidade é um termo que parece se distanciar, de algum modo, das concepções fechadas do pensamento colonial. No entanto, assevera Hall (1996):

\footnotetext{
Assim, tanto o discurso da "raça" quanto o da "etnia" funcionam estabelecendo uma articulação discursiva ou uma cadeia de equivalência discursiva entre o registro socialcultural e o biológico, fazendo com que as diferenças em um sistema de significados sejam inferidas através de equivalentes em outra cadeia. Por tanto, o racismo biológico e a discriminação cultural não constituem dois sistemas distintos, mas dois registros do racismo. É mais apropriado falar não de "racismo" versus "diferença cultural", mas de "duas lógicas do racismo" (1996, p. 71).
}

Pelo acima citado, o racismo, como integrante de uma cadeia discursiva, se bifurca e pode criar outras roupagens. De alguma forma, o discurso cultural se diversifica. Retoma-se aqui, o já citado multiculturalismo plural para tentar ler o momento sóciohistórico. E esse multiculturalismo plural pode ser encarado como uma luz no fím do 
túnel para se compreender que a concepção da identidade se dá num emaranhado de nuances, como numa imagem do caleidoscópio?

Esse modo diversificado de encarar a identidade aponta para a questão do hibridismo, que é um processo cultural que permanece em variação, em ambiguidade, em trânsito. No dizer de Hall (1996), “ o hibridismo não se refere a indivíduos híbridos, que podem ser contrastados com os 'tradicionais' e 'modernos' como sujeitos plenamente formados. Trata-se de um processo de "tradução cultural, agnóstico uma vez que nunca se completa, mas que permanece em sua indecidibilidade" (HALL, 1996, p. 76).

Todavia, é arriscado não vincular o hibridismo, como tradutor cultural, ao complexo processo de constituição de identidade. O sujeito sociológico, como apresentado por Hall, encontra-se demarcado, enquanto o sujeito pós-moderno tem múltiplas vinculações, entre outras, às condições sociais, materiais; e simbólicas observadas ao sentido que se dá às práticas sociais, aos sistemas classificatórios, à percepção de que as identidades não são unificadas. Essas vinculações apontam como as identidades são formadas e mantidas.

Com isso, Silva (2000, p. 73) propõe cautela ao pensar no "multiculturalismo", na "identidade" e na "diferença", que são questões centrais nos estudos culturais. Ele reflete que o multiculturalismo pode embutir uma ideia vaga de diversidade e, ainda, podem restar dúvidas se as questões da identidade e da diferença possam se esgotar ali. $\mathrm{O}$ autor esclarece o porquê destas inquietações em relação ao multiculturalismo ao expor que "as identidades e as diferenças não são, nunca, inocentes" (SILVA, 2014, p. 81).

Nesse ponto, é possível lembrar o conceito de multiculturalismo plural citado anteriormente, para refletir sobre seu impacto na construção de identidades de grupo específico como o de meninas negras. Há uma pergunta que se insere nesse texto que é: por que o conceito de identidade é importante? E, ainda o que se desdobra com essa questão: se a discussão sobre a identidade da menina negra poderá reverter os processos discriminatórios pelos quais passa a mulher negra, mesmo no século XXI.

Isso implica que a identidade é um conceito que centraliza questões contemporâneas em vários níveis; isto inclui questões étnicas e de gênero. Evidencia que a necessidade de identificação de grupos marginalizados ainda é relevante. Pensar em identidade e diferença, tanto de modo global como local, é recorrer ao entendimento de como esses conceitos se inserem no campo cultural e relacionam-se com o processo de representação. Ou seja, um processo cultural que estabelece identidades individuais e coletivas. Assim, a representação pode ser observada como reflete Woodward (2014): 
A representação inclui as práticas de significação e os sistemas simbólicos por meio dos quais os significados são produzidos, posicionando-nos como sujeito. É por meio dos significados produzidos pelas representações que damos sentido à nossa experiência e àquilo que somos. Podemos inclusive sugerir que esses sistemas simbólicos tornam possíveis aquilo que somos e aquilo no qual podemos nos tornar (WOODWARD, 2014, p. 17-18).

Então, até nesse ponto do texto, o conceito de identidade submeteu-se aos processos ora biológicos, sociais ou políticos. A cultura é, pois, o lastro que surge e de onde tais processos serão ressignificados nas práticas de significação. Tais práticas envolvem o poder de definir o que é ou não incluído.

Rascunha-se uma identificação para a menina negra a partir dessas práticas de significação: sujeito híbrido, como colocado na citação acima, nas expressões "aquilo que somos" ou "podemos nos tornar". Ou seja, ser menina negra significa estar sujeito a vir a ser. Interessa pensar nas vivências que produzem significados e envolvem relações de poder.

Ao observar a menina negra no espaço sociocultural e como suas experiências a colocam dentro ou fora dos esquemas de pertencimento a uma comunidade nacional, vêse sua proximidade com o sujeito em crise e fragmentado estudado por Hall (2006, p. 39). O sujeito pós-moderno está em crise por romper com anteriores momentos históricos. A crise do sujeito pós-moderno está aliada às múltiplas identidades que se observam no coletivo ou no individual. O sujeito pós-moderno é, pois, portador de identidades múltiplas, descentradas, fragmentadas e deslocadas. Tais categorias exprimem a indefinição de identidade e apontam para novas articulações da cultura.

A construção das identidades da menina negra, na atualidade, mediante as contribuições teóricas dos estudos culturais, abre-se como um campo de discussão que deve envolver a literatura como instrumento, como categoria discursiva que pode subverter a questão da identidade dita fixa. A esse respeito, pensar na menina negra como um sujeito híbrido é uma tentativa de demonstrar a mobilidade de sua identidade, que se constitui perante esses aspectos ligados ao movimento, ao cruzar de fronteiras, ao hibridismo.

No esclarecimento de Silva (2000, p. 87), a identidade híbrida distancia-se da formação original, "embora guarde seus traços". O autor justifica que o processo de hibridização pode provocar confusão para a suposta "pureza e insolubilidade referente aos grupos que se reúnem sob as diferentes identidades nacionais, raciais ou étnicas”. Nesse contexto, pensar como a identidade da menina negra pode ser representada através dos discursos culturais é refletir sobre o papel dos sistemas simbólicos. Inclui também 
repensar o papel da literatura como o local, o espaço discursivo para estabelecimento e emergência desse sujeito em construção.

Portanto, este texto dialoga com Bhabha (2010, p. 19), pois se estima que há um local onde se situam os discursos construtores da identidade da menina negra como sujeito cultural. Esse espaço discursivo localiza-se na fronteira de discursos já instituídos, como o de gênero, de raça e de etnia. Isso implica que esses discursos, ao transitarem nesse espaço, entrecruzam e produzem figuras complexas de diferença e de identidade.

\section{6. Espaços de agenciamento da identidade de gênero da menina negra}

O espaço contemporâneo opera através do reconhecimento das múltiplas alternativas de historicizar o mundo. É isso possível ao se olhar além dos limites, das fronteiras de discursos homogêneos, como sugeriu Bhabha (2010). Valendo-se dessa meta, a literatura infantil contemporânea pode ser encarada como esse espaço de discussão, que inclui o corpo negro feminino, discursivo e redimensionado, na construção da identidade da menina negra.

Assim como para a mulher, a história mundial da infância é marcada por diferenças de oportunidade e de visibilidade entre gêneros. Alguns exemplos são observados por Stearns (2006, p. 32) em relação ao desproporcional valor entre o trabalho do menino e da menina, da esposa e do esposo nas sociedades agrícolas. A ênfase recai sobre o poder do pai e o controle da propriedade. As meninas são consideradas inferiores ao menino. Em sociedades chinesas, por exemplo, o infanticídio de meninas era tido como algo inquestionável, enquanto o nascimento de um menino era bem-vindo.

No Egito, embora os meninos e meninas não fossem discriminados no nascimento, após o desmame, as diferenças eram acentuadas com o treinamento e a supervisão que os pais ofertavam apenas aos meninos. As meninas eram menos vitimadas pela cólera paterna, no entanto, tinham parcas oportunidades. Em vários aspectos, o corpo feminino foi vitimado pelas sociedades mediante o oferecimento de "oportunidades" que confirmavam um espaço social de desigualdade.

Como definir esse corpo infantil feminino senão por características ou marcas de pertencimento de desvalor? É possível que esse corpo seja considerado abjeto, correndo o 
risco de mau uso do termo, no sentido dado por Judith Butler ${ }^{12}$. Isto é, cujas vidas não são consideradas vidas e cuja materialidade é entendida como não importante.

O corpo abjeto é uma característica facilmente acoplada à pessoa negra, em especial à menina ou menino negros. Isso decorre das marcas profundas da escravidão, ainda presentes no corpo e na alma da pessoa negra. $O$ discurso da vitimização não deve ser o mote para seguimento deste texto, no entanto, ele não pode ser totalmente descartado no entendimento da constituição da identidade negra. $\mathrm{O}$ espaço por onde esses corpos negros são itinerários discursivos, podem ser repletos de significação.

No imaginário brasileiro do período pós-abolição está presente uma multidão de pessoas sem pertencimento, sem lar, sem casa. O quem somos tem muito a ver com o modo de estar no urbano, na sociedade. Então, esses corpos abjetos são os mesmos que se tornaram símbolo da sujeira, do feio, do que devia ser banido do meio das ruas das grandes cidades brasileiras e que foram assentados fora do que é civilizado.

Um exemplo pertinaz quanto à situação da criança negra na sociedade urbana (Rio de Janeiro e Bahia e, principalmente, na região das minas do século XVIII) é dado por Mary Del Priori (2013, p. 107). Ela aponta o descaso das autoridades locais em relação ao cotidiano das crianças escravas, as pobres e as mulheres. Não se falava da situação desses grupos.

Dialogando com Ariès, Priori (2013, p. 110) assevera que não se esperava que as crianças sobrevivessem ao nascimento e à primeira infância. Isso explica porque a criança somente é mencionada nos documentos oficiais "marginalmente" ou quando "participa de uma ação". Mas, a que criança se refere? Certamente isso não implica a criança negra, pois ela era ainda mais esquecida. A criança tinha alguma expressividade na sociedade: em festas, rituais, no entanto, por sua "propensão" à morte, ela era encarada como um ser que logo poderia ser substituído.

As crianças escravas que habitavam as regiões das Minas Gerais tinham pouco valor, não eram consideradas investimento por que o presente carecia de mão-de-obra e não dava para esperar. Ao contrário, as mães dessas crianças pequenas eram importantes para serem amas de leite, enquanto seus filhos eram visivelmente um estorvo, mais uma boca para ser alimentada. Daí os proprietários não se importarem com sua sobrevivência.

A partir do momento que a população de mulatos e de filhos ilegítimos crescia, verificou-se um clima de tensão causado pelos batizados e alforrias de seus pais brancos, posto que muitas mulheres viviam em concubinato, adquiriram alforria e posses. No

\footnotetext{
${ }^{12}$ Extraído da entrevista de Judith Butler publicada pela Revista Estudos Feministas v. 10, n ${ }^{\circ} 1$, janeiro de 2002.
} 
entanto, por maior que fosse a ascensão social, a mulher negra e a criança negra vivenciavam processos de discriminação, muito embora atuassem na sociedade inclusive como mulheres de negócios, em muitos casos. Priori (2013) assevera:

Diferente era o caso dos que nasceram naquele local, fruto da união, nem
sempre fortuita, de homens brancos e de mulheres "de cor", escravas ou livres.
A maioria desses nascimentos se deu fora do casamento dos pais. As listas de
batizados nos mostram que a grande maioria das crianças nascidas no decorrer
de todo o século XVIII, é de filhos ilegítimos, alguns com pais ignorados e
outros com paternidade reconhecida pelos genitores. Diziam os informantes,
isto é, as autoridades que davam conta da situação o local ao Conselho
Ultramarino, que dificilmente um homem branco se casava com uma mulher
"preta" e que os mulatos não costumavam se casar, mas que viviam em
concubinato (PRIORE, 2013, p. 121).

Há um corpo infantil ilegítimo, fruto de um meio altamente invisibilizador. Há um corpo negro escravizado e estigmatizado por isso. E estas marcas de pertencimento não foram extraídas do imaginário brasileiro ao se referir à criança negra. A sociedade urbana industrial seguiu os mesmos padrões de ilegitimidade da pessoa negra, da sociedade mineira colonial. O corpo infantil negro se deslocava pelas ruas de São Paulo, operário da indústria têxtil, vitimizado por uma carga horária exaustiva, e sujeito à acidentes.

O corpo infantil negro "abjeto" é produto da sociedade capitalista da qual faz parte. Os discursos que decorrem deste corpo abjeto ainda rodeiam o imaginário brasileiro. Na literatura, a presença da personagem negra está repleta de características de cunho pejorativo. Como romper com o poder estigmatizador das construções imagéticas próprias da literatura infantil na contemporaneidade?

Talvez o primeiro passo seja conhecer os caminhos que constituíram esta rede de preconceito à brasileira, falseado pelo discurso da igualdade. O corpo negro infantil está impregnado desses discursos sociais. O corpo negro infantil atingiu um grau de complexidade que necessita um olhar mais apurado para concebê-lo. Assim, em seu texto, Fragmentos de gênero, Frangella (2009, p. 425) traz várias e importantes reflexões sobre a situação de crianças e adolescentes moradores de rua. Ela discute a situação de corporalidades construídas por esses meninos e meninas, marcadas pelas características de: "fluidez, fragilidade, circularidade e fragmentação". E estas características são causadas pelos seus modos de vida, em especial de como eles se deslocam no espaço urbano.

Um ponto inicial é que esses corpos tocam o espaço urbano, mas não pertencem a ele. De algum modo, o espaço percorrido no circuito urbano é a moradia, a rua que ao mesmo tempo acolhe e expulsa, e por isso, tornam-se dimensões relevantes. O espaço 
urbano está repleto de discursividade e propõe o redimensionamento das aprendizagens de valores. Quais as marcas, as práticas corporais e delineações de gêneros disponíveis?

Ao que parece, a autora propõe a ambiguidade como resposta para as construções corporais entre meninos e meninas. Embora partícipes de ambiente hostil, papéis de meninos e de meninas evidenciam relações desiguais, tendo em vista as experiências, vivências e oportunidades. A partir disso, a autora propõe: “O mundo da corporalidade é enunciativo das contradições e das relações fragmentárias criadas a partir da ocupação que fazem das ruas" (FRANGELLA, 2009, p. 412).

$\mathrm{O}$ corpo da menina de rua fragmenta-se por estar aberto e propenso às investidas violentas das avenidas urbanas, bem como a processos disciplinares das instituições de amparo. Para adquirir visibilidade, meninos e meninas negociam com o espaço urbano através de performances corporais, pelo uso de técnicas e práticas de sobrevivência.

A rua é o espaço de experiências ambíguas, o local em que os sujeitos, protagonistas da exclusão, vivenciam eventos públicos e privados misturados, indicando discursos confusos, dialéticos. Neles a ordem dos prédios, das casas e edifícios, representantes de discursos que exprimem fixidez, se contrapõe aos discursos da insalubridade das ruas. O sujeito menina negra experiencia esse espaço ora de modo nômade, ora de modo fixo.

Além das marcas visíveis da vida itinerante, como a sujeira, os trapos, as cicatrizes, as marcas indeléveis no corpo da menina são os estigmas que a tornam mais e mais excluída do processo social. Essas marcas da vida real transpuseram os limites ficcionais, mas o espaço de voz ainda é discutível ali. Esperava-se, por exemplo, que pela tão aclamada "maestria estética" de Monteiro Lobato, corpos, socialmente, abjetos, emudecidos, itinerantes como o da menina negra obtivesse um espaço de reivindicação, de construção de um imaginário positivo.

A despeito de Lobato $^{13}$, o quadro de visibilidade positiva da menina negra no universo ficcional vem adquirindo volume expressivo. Urge ouvir o corpo negro infantil, e essa escuta parte da busca por representação à partir de personagens que experienciam a vida de um modo mais humano. Distante dos esquemas de animalização e servidão, consolida-se como um caminho de reconstrução de outro cotidiano para a menina negra, herdeira dos processos de discriminação da mulher negra brasileira.

O processo de representatividade de grupos historicamente subalternizados e invisibilizados não é simples. Isso implica que a representação deve ser encarada como

\footnotetext{
${ }^{13}$ Refiro-me ao texto Negrinha, de Monteiro Lobato, como exemplo de contrução da imagem negativa da menina negra na literatura.
} 
produto da interação humana e sua comunicação. Segundo Moscovici (2011. p. 41), as representações sociais são capazes de influenciar o comportamento do indivíduo dentro de uma coletividade. Ao afirmar que "pessoas e grupos criam representações no decurso da comunicação e da cooperação, percebe-se que eles se constituem como realidade social por um objeto coletivo sustentado pela tradição, por um processo de associação e de analogia".

Pensar como as representações sociais são ligadas à identificação dos papéis sociais da mulher negra e da menina negra requer refletir sobre como diluir os processos hegemônicos responsáveis pela construção de sua imagem social. O modo como se instituiu a representação do elemento feminino negro na sociedade brasileira, seja a mulher ou a menina, implica na construção de um imaginário reprodutor das estratégias de racismo e de discriminação.

A imagem desqualificada da pessoa negra na sociedade brasileira, repercute nas relações sociais, públicas ou privadas. A arte está repleta de exemplos. Para tal, recorrese ao vídeo "O tal teste da boneca"14. No vídeo, um interventor branco apresenta duas bonecas: uma de cor branca e outra em tom marrom escuro, para várias crianças negras, individualmente. $\mathrm{O}$ interventor realiza as seguintes perguntas:

1. Qual boneca é negra?

2. Qual boneca é bonita?

3. Que boneca é legal?

4. Que boneca é má?

5. Qual boneca é agradável?

6. Que boneca é feia?

7. Que boneca parece com você?

As respostas das crianças negras são sintomáticas. Não é o caso de avaliar a metodologia do interventor ou sua intencionalidade, mas interessa as respostas e os gestos das crianças ao responderem. Quando respondem qual boneca é feia, todos apontam para a bonequinha marrom, e tocam, agressivamente, a boneca. Para as crianças entrevistadas, a boneca legal, agradável e bonita é branca. Do outro lado, a boneca feia, má é a marrom, a negra.

Então, após indicarem os binarismos branca boa, negra má, as crianças respondem ao interventor que a que se parece com elas é a marrom, ou a boneca negra. O olhar triste

\footnotetext{
${ }^{14}$ Ao acessar este título on line, vários vídeos são relacionados. Estes vídeos são decorrentes do estudo do psicólogo afro-americano Kenneth Bancroft Clark, de 1947.
} 
e desapontado das crianças ao se identificarem com tal boneca negra má-feiadesagradável oferece leituras profundas. Ele evidencia a sutileza de como o preconceito se confirma, e, dialogando com Moscovici (2011), como a autorrepresentação das crianças negras, em especial das meninas negras, está condicionada ao mundo exterior, às construções sociais, tradicionalmente fortalecidas. Ainda, uma resposta fica marcada: a da criança que afirma que a boneca branca é a mais agradável porque tem "olhos azuis".

O teste de Clark serviu de inspiração para a produção de diversos vídeos em lugares e épocas diferentes. As respostas são muito próximas das proferidas no vídeo americano. Uma ou outra criança sinalizou uma postura diferente, ainda que discretamente. As reflexões que podem ser tiradas dessas experiências são múltiplas. Mas, se se buscar olhar pelo ângulo da criança, é possível observar que um modelo universal de pessoa aceita socialmente lhe foi apresentado.

A criança negra não parece querer ser ligada ao que não é considerado bonito, nem limpo, nem agradável, nem aceito. A negação do corpo negro é uma das vertentes que se evidenciam e dão indícios da necessidade de rompimento com processos hegemônicos identitários. Vale recordar em Shohat e Stam (2006, p. 93) que "o discurso eurocêntrico degradou sistematicamente a África ao considera-la deficiente de acordo com a criação de hierarquias arbitrárias".

Os resultados da experiência de Clark refletem essa postura arbitrária. Assim como dialogam com o que assevera Munanga (2009, p. 17) ao tratar do racismo à brasileira ou o mito da democracia racial, sustentado pela prática ideológica do embranquecimento. Esta prática diz respeito ao processo de fugir das características fenotípicas do negro e identificar-se cada vez mais com o branco. Ao se identificar com pessoas não negras, a pessoa negra passa pelo processo de negação e de assimilação cultural. Contrariamente, o que deve importar ao negro na sua "busca por identidade é a tomada de consciência histórica da resistência cultural e a reivindicação de um espaço na cultura brasileira" (MUNANGA, 2009, p. 17).

Isto posto, reflete-se que a identidade negra brasileira não é tão simples de ser construída. Considera Munanga (2009, p. 63) que "as cercas das identidades culturais brasileiras vacilam". Para o autor, trata-se de observar as especificidades dos problemas dos negros. E isso implica afirmar que a busca da identidade negra brasileira não se circunscreve à divisão de luta dos oprimidos. Não, os problemas dos negros brasileiros devem ser encarados por eles mesmos, principalmente no que se refere à alienação do seu corpo, de sua cor, de sua cultura e de sua história, de sua inferiorização e de sua baixa autoestima. 
A partir de Munanga (2009, p. 63), a negritude pode ser compreendida como um ato de resistência, uma política de contra-aculturação. A menina negra que senta diante dos dois simulacros que são as bonecas negra e branca, precisa fazer uma escolha que demonstre a sua noção de pertencimento. Ao considerar que é mais agradável ter pele clara e olhos azuis ela nega a sua origem negra, ela se anula socialmente? A menina chicana que participa do mesmo teste, identifica-se com a boneca branca, porque a "morenita" pode ser uma ladra ou qualquer coisa assim.

Este comportamento de algum modo essencializa o processo de pertencimento, no sentido de que não há como considerar um modelo único de identidade para vários grupos. Embora parta da matriz biológica que preconiza a cor da pele, dos olhos, do jeito dos lábios na construção da identidade negra, não se pode descartar que o "conjunto" dos traços físicos ou morais são considerados no comportamento de recusa ou aceitação, e na identificação.

Discutir a identidade negra, como já refletido no texto, requer pensá-la de modo plural e não negligenciar as dimensões pessoais e sociais que se interligam no cotidiano das relações históricas e culturais. Inclui pensar a "diversidade cultural" que envolve as questões étnicas e raciais. Entender o étnico como o pertencimento ancestral e étnico racial dos negros e a identificação pela cultura, tradições e monumentos históricos e territórios. E, compreender a necessidade de superar a discriminação racial, não para acirrar o conflito entre diferentes grupos, mas para "desmitificar o racismo" (GOMES, 2005, p. 51).

A identidade negra feminina é construída no contexto social de modo complexo e amplo. Esse modo singular de ser sujeito negro feminino requer uma representação que atenda às suas especificidades enquanto grupo marginalizado ou de minorias. No entender de Chaves (1970) $)^{15}$, “minorias" referem-se a minorias nacionais, que relacionam-se a grupos raciais ou étnicos em "situação de minorias". Isto é, minorias traduz-se nas interrelações de poder, de superioridade da maioria sobre a inferioridade da minoria.

"Minorias" são grupos cuja voz foi cerceada no bojo das relações sociais. Daí reflete-se que o que desautorizou as vozes negras femininas está relacionado ao longo processo histórico de subalternização. A célebre frase de Spivak prossegue: "Pode o subalterno falar?". Para resolver a questão do cerceamento da voz do subalterno, no caso a mulher negra, Spivak aponta algumas saídas. Inicialmente, reporta à questão da representação em duas dimensões: a fala mediada ou re-apresentada.

\footnotetext{
${ }^{15}$ Texto: Minorias e seu estudo no Brasil. L. G. Mendes Chaves. Revista de Estudos Sociais, Fortaleza, v.1, n. 1 p. 149-168, 1970. Disponível em: www.repositorio.ufc.br/handle/reufc/4487
} 
De algum modo, o discurso heliocêntrico reproduz as relações sociais de produção ao evocar o oprimido como o ser abjeto. Ao termo "subalterno" estão agregados conceitos de inferioridade, de subordinação, de dependência. De modo contundente, a palavra "Ocidente" indica a posição de agência do Sujeito soberano, dominador, imperialista.

Se historicamente a menina negra como corpo abjeto e subalterno não tem voz, ela é assim representada em discursos literários. A questão é que a própria historiografia literária refere-se à menina negra de modo que ela não sente referendada. Falar por é evidenciar alguém, é dar-lhe possibilidades de visibilidade? Esta proposta de representatividade é um tanto combatida, mas ainda cabe nesse discurso. Nas dimensões de representação, a menina negra é, muitas vezes, representada por escritoras negras que mediam ou lhe dão voz.

Quando uma representação se legitima? Duas palavras são pertinentes para se refletir quanto a isso, "identidade e substituição". Estes termos são retirados dos estudos de Iris Young ${ }^{16}$ (2000) sobre representação política dos grupos de minorias, que discutem como se dão as relações comunicativas inclusivas em sociedades mais complexas. O que é apontado, entre outros, é "o caráter excludente das representações".

A autora reflete que em várias democracias, a discussão da representação das minorias está incorporada às agendas públicas, como exemplo, a representação específica das minorias raciais ou étnicas nos Estados Unidos. No entanto, adverte Young que há objeção em torno dessa questão por ela alinhar, no mesmo grupo, atributos e interesses comuns de grupos de gênero, étnicos, classe ou religião completamente díspares. A esse aspecto, assevera Young (2006):

\footnotetext{
Assim, o processo unificador requerido pela representação de grupos buscaria congelar relações fluídas numa identidade unificada, o que poderia recriar exclusões opressivas. (...). Numa versão dessa crítica, nenhum representante único poderia falar por qualquer grupo, já que os indivíduos que o compõem mantêm relacionamentos por demais entrecruzados (YOUNG, 2006, p. 142).
}

No entanto, a própria autora aponta que estas práticas representativas são vistas, por muitos, como importante ferramenta de inclusão política. A controvérsia gira em torno do entendimento de que a representação se dá por substituição e identificação. Young, em contrapartida, propõe o conceito de representação como um relacionamento diferenciado.

\footnotetext{
${ }^{16}$ Representação Política, Identidade e Minorias. Do original Inclusion and democracy, 2000, de Iris Marion Young. Traduzido por, Alexandre Morales, publicado em Lua Nova, São Paulo, 67, p. 139-190, 2006.
} 
Do contrário, a necessidade de representação através da relação de semelhança do representante e representado, ou pela co-presença, pode gerar um descompasso, segunda a autora. Ela explica que ocorrerá um paradoxo tendo em vista que a representação, se necessária, pode se tornar impossível. Então, Young (2006, p. 148) justifica que uma representação deve ocorrer em um processo que transpareça uma "relação mediada dos eleitores entre si e com um representante". Estabelece-se uma rede de diálogo de diferenças entre atores plurais.

Assim, dialogando com Young (2006), a legitimação da representação política, dar-se-á não propriamente por pôr-se, no caso pelos eleitores, por alguém, mas pela interação. Não é certo que este processo de representação através da mediação atenda o grupo minoritário das meninas negras, pela dificuldade de vinculação destas com seus representantes. É possível que haja uma necessidade de consciência de participação pelo diálogo.

Então, para ajustar a representação da menina negra no processo de relacionamento diferenciado proposto por Young, convoca-se a mulher negra como interlocutora. Assim, o processo de representação da menina negra segue de modo mais complexo, profundo. Há necessidade de encaixes de vozes para que a menina negra seja representada? Tornada protagonista a menina negra tem a legitimidade de participação nos processos de representação?

Young (2006, p. 152) procura se apoiar em Hanna Pitkin e em sua sugestão de que a autorização é um importante indício de representação. E tem a preocupação em considerar que o representante tem um significado específico na atividade representativa, que é estar em diálogo aberto e sujeito à prestação de contas.

Então, no texto de Hanna Pitkin (2006) Representação: palavras, instituições e ideias $^{17}$ ela propõe uma definição de representação como atividade humana, indo além da postura de agir pelo outro, isto é, uma atividade de apresentar, de figurar. Ela assevera que a representação é "um meio que comporta grandes conflitos sociais perigosos para um fórum central único". E ainda, segundo a autora, "a representação é, em grande medida, um fenômeno cultural e político, um fenômeno humano" (PITKIN, 2006, p. 16).

E, valendo-se do significado, represent (como observado pelos tradutores) é uma palavra que significa trazer a própria pessoa, ou outra pessoa, à presença de alguém; simbolizar ou encarnar concretamente; trazer à mente. Essa dimensão democrática da representação pode indicar uma escolha dicotômica entre um representante e os seus

\footnotetext{
${ }^{17}$ Do original "Representation". Traduzido por Wagner Pralon Mancuso e Pablo Ortellado. Publicado em Lua Nova.
} 
eleitores. Entretanto, para Pitkin, “o equilíbrio necessário acontecerá apenas se cada representante buscar de fato os interesses dos seus eleitores" (PITKIN, 2006, p. 37).

Existirá, portanto, uma relação de utilidade em que o representante precisa do eleitor para sua reeleição e, por sua vez, o eleitor não segue imparcial. Pitkim (2006) explica que ele é o guardião de suas necessidades. Então, há em questão um jogo de interesses que desemboca no princípio da deslocabilidade que alimenta esta relação representates-eleitores.

Refletir sobre a representação de grupo especificamente minoritário como o das meninas negras requer, entre outros, pensar nas possibilidades de visibilidade através da constituição dos espaços de voz. Se a menina negra como subalterno fala a sua fala, pode não ser ouvida ou compreendida na sociedade capitalista. Na busca por representação da menina negra há necessidade de se lançar mão da multiplicidade de suas formas. Ora ela é apresentada, figurada ou mediada. Não há ainda, como fugir deste esquema de representação.

No campo da literatura infantil contemporâneo figuram personagens negras que vêm ocupando outros espaços. Pelo protagonismo infantil na literatura, é possível compreender que a sociedade, em especial a brasileira, vem rompendo com o silêncio e a invisibilidade imputados à menina negra. E esse comportamento deve-se, em grande parte, ao movimento feminista negro, que tem procurado estender seus braços e alcançar cantos completamente esquecidos de nossa sociedade.

O modo como a menina negra é representada no imaginário social é fruto de um vergonhoso processo de discriminação e de preconceito. É produto de uma sociedade baseada em diferenças de classes sociais, de gênero e etnia. É fruto de uma relação de dominador adulto e dominado criança. Como esclarece Fúlvia Rosemberg (1985) na introdução de seu texto Literatura infantil e ideologia, é importante compreender o "significado social do ser criança".

Assim, em seus estudos, Rosemberg (1985) procura por em cheque os processos de discriminação contra grupos, arbitrariamente, esquecidos. Ela presumia, na época, que no campo da literatura infantil a inserção de temas sobre a discriminação das minorias fosse se intensificar. E, na contemporaneidade, sua hipótese se confirma. O campo da literatura infantil tem se renovado em todas as direções: estéticas, sociais, políticas, psicológicas, linguísticas.

O olhar perscrutador de Rosemberg (1985) evidenciou o estudo da relação adultocriança inserido na literatura infanto-juvenil, no sentido de observar as possíveis relações 
binárias e polarizadoras: dominador-dominado, nas categorias sociais. Ou seja, a curvatura do olhar se volta para o adulto produtor mais do que para a criança receptora.

Como iniciativa, a autora propõe um processo de partilha. Isto é, uma comunicação entre e não para, no sentido de romper com a desigualdade de poder. E ela acrescenta: "Na sociedade-centrada-no-adulto a criança não é. Ela é um vir a ser. Sua individualidade deixa de existir. Ela é potencialidade e promessa". Portanto, os ideais do adulto se projetam na infância. Uma infância idealizada pelo adulto que, segundo a mesma, "encarna a inocência e a autenticidade, ainda não deformados pela sociedade" (ROSEMBERG, 1985, p. 25).

Esse é o ponto de crítica da autora que deve ser considerado. Ou seja, da tensão no encontro entre uma infância idealizada e a sociedade em transformação. O paradoxo é tal que, se essa sociedade centrada no adulto não se modifica por causa dessa infância estilizada, a idealização se submete aos seus paradigmas.

Rosemberg (1985, p. 26) dialoga com Ariès que discute o anacronismo revelado no uso de roupas e de brinquedos pelas crianças. No século XIX, após abandonar as roupas de bebês, as crianças vestiam-se como adultos. Quanto às bonecas, que surgiram primeiro como objeto de culto religioso, transformam-se em objeto de utilização comunitária, em brinquedos. Ao referir-se ao pensamento de Ariès, Rosembeg cita-o: "a infância torna-se o reservatório dos usos abandonados pelo adulto".

Acusa a autora a necessidade de reversão do conteúdo do que é escrito para a criança, tendo em vista a posição do adulto como o produtor universal e da criança como a receptora. Ao dissertar sobre o conteúdo das obras da pesquisa, Rosemberg reflete que há um modelo pedagógico dominante no conjunto das obras. Para ela,

\footnotetext{
tais estórias se caracterizam pela idealização do universo e da humanidade, tanto quanto assumem a pedagogia do modelo ou do contramodelo. A idealização total, maciça e homogênea da natureza e da humanidade aparece em poucas narrativas. Aqui o cotidiano contraditório, as frustrações e os conflitos foram banidos. O jovem leitor é protegido e tratado em menor. Não se permite que sua inocência e sua sensibilidade sejam ultrajadas ou feridas. A criança não tem o direito de saber o que quer, mas apenas aquilo que o adulto considera digno ou bom que ela saiba. O conteúdo do livro é expurgado. É a pedagogia do modelo (ROSEMBERG, 1985, p. 60).
}

A realidade imaculada preconizada nos livros, pelo que mostra a pesquisadora, é perturbada quando um indivíduo maniqueísta resolve perverter a ordem. O tipo de personagens evidenciados dentro da pedagogia do modelo serve à trama, de função linear e sem contradição. Assim constituem-se personagens (nem mesmo fadas e bruxas) que não conseguem romper com o esquema maniqueísta para a eclosão da contradição. O que 
pode ocorrer no final das tramas maniqueístas segue duas vertentes: ou o bem vence o mal, que é destruído; ou "o mal é transitório e o culpado corrigido".

O bem é belo, o bom é justo e está acima de qualquer suspeita, sem contradição e detentor do poder. Esses são os atributos que a pesquisadora levanta das personagens analisadas. A relação de dominador-dominado se evidencia na pesquisa de Rosemberg (1985, p. 64), quando ela constata, pelo volume pesquisado, que o poder está nas mãos dos adultos, eles são os modelos, os perfeitos, individuais e sociais. Em contrapartida, a criança é o elemento denegrido que deve ser "curado" pela educação.

A pesquisa de Rosemberg (1985) teve como conjunto de amostras 168 títulos de autores do eixo Rio-São Paulo, em grande maioria. O período escolhido foi de publicações entre 1955-1975. Cerca de 45\% do total, refere-se às obras coeditadas pelo INL. Entre as várias particularidades levantadas, a pesquisadora ressalta que a maior parte da produção literária infanto-juvenil, desde a autoria, publicação e ilustração, é de dominação masculina.

Com o claro objetivo de analisar o conteúdo para crianças, tendo em vista a produção adulta a pesquisa foi realizada. A autora apresentou três tendências diferenciadas da produção literária infantil, sendo que a primeira se refere a histórias moralizantes onde a criança subjacente é o ser educável e domesticável, e a característica principal da produção é a idealização do universo e humanidade.

A segunda tendência é considerada como condição de argumento e tem por autores os que se dedicavam também à literatura para adultos. Observa-se a presença do prazer em lugar do tom moralizante ou de tese. O narrador é o cúmplice e diminui a distância na anterior relação criança-adulto.

A terceira tendência do conjunto de histórias analisadas pela pesquisa diz respeito ao grupo de autores que migraram da literatura de adultos e converteram-se para a literatura infantil. Esse grupo representa o movimento de mudança na literatura infantil, de algum modo já tratado nessa análise. Uma característica interessante dessa tendência apontada pela autora é o rompimento com o idealismo e maniqueísmo e a evidência dos conflitos intrapsíquicos e sociais. Desse modo, a personagem infantil é arrancada da "doce inocência" e lançada no espaço do conflito.

O falar para dá lugar ao falar com, ou seja, a relação adulto-criança se redimensiona com a presença do narrador-criança. Além dessa, a transposição simbólica do conflito e a prerrogativa da ação sobre o verbo são marcas do comportamento diferenciado do adulto. Ao que parece é esse o ponto capital da análise de Rosemberg 
(1985), por indicar, entre outros, um sentido diversificado, por refletir as relações reais da sociedade, manipulando imagens concretas (ROSEMBERG, 1985, p. 75).

O que se espera da produção de literatura infanto-juvenil, na visão da pesquisadora, é não apenas demonstrar os modelos de relacionamentos existentes, mas propor outros. Vale ressaltar, entretanto, que a questão da discriminação racial, as questões de gênero e outras, foram também evidenciadas na pesquisa. Destaca-se do levantamento realizado, a constatação da autoria majoritariamente masculina, branca, tanto no texto quanto em sua ilustração.

Em relação à ilustração, a pessoa negra é sempre estigmatizada num discurso, predominantemente, preconceituoso, que relaciona a cor escura ao que é ruim, negativo. Como assevera Rosemberg (1985, p. 81): “A branquidade é a condição normal e neutra da humanidade; os não-brancos constituem uma exceção". Ao que deixa transparecer em suas colocações, a autora observa que o humano está relacionado ao tom branco; ao que é animalizado, à cor preta ou escura.

Dentre as relações elencadas, a autora atenta para o fato de que ao branco a individualidade é preservada, no entanto, ao não branco, negro ou índio, observa-se a perda da "unicidade". Curiosamente, a apresentação de mulheres negras, adultas, na ilustração se dá de modo a anular o seu papel social, isto porque o que aparece não é a mulher comum e sim a empregada, a pessoa de avental, de lábios exagerados, totalmente estereotipada. Não há referência à menina negra.

Porém, a menina negra é contemplada na preocupação da autora. Ela discute sobre o campo de ação da luta feminista e critica o seu único alvo (àquela altura): a mulher. Pesarosamente, observa que "esta postura obscurece e exclui outros grupos, no caso a criança" (ROSEMBERG, 1985, p. 101).

Em que pese a época em que foi realizada, esta pesquisa é importante para a análise da representação da menina negra na literatura infantil na contemporaneidade, pois são vários os elementos que podem ser utilizados nas presentes análises. A perspicácia da autora se dá em várias vertentes evidenciadas na pesquisa. Entre elas, destaca-se aqui a autoria feminina e o protagonismo infantil como um caminho para dirimir processos de controle e de desigualdade social. Isto pode colocar uma importante proposta de redimensionamento de polaridades: da criança para o adulto, como rompimento do processo hegemônico presente na produção cultural. 
Dentre as pesquisas consultadas para esta tessitura, cita-se a pesquisa realizada por Leda Cláudia da Silva Ferreira ${ }^{18}$ que dialoga com as ideias de Fúlvia Rosemberg, na qual se baseia. Em sua pesquisa intitulada A personagem do conto infanto-juvenil brasileiro contemporâneo: uma análise a partir de obras do PNBE/2005, a autora investiga personagens do acervo do PNBE de 2005, desenvolvido pelo MEC. Isso implica no conjunto de 300 obras, distribuídas em 15 acervos que contêm 20 livros cada. Caracteristicamente, em geral, o acervo engloba gêneros diversos, de autores e nacionalidades diferenciadas.

O estudo produzido por Ferreira (2008) objetiva investigar questões de pluralidade cultural na literatura brasileira contemporânea para crianças e jovens. Destacam-se aqui alguns pontos capitais que podem contribuir com a discussão em torno da identidade da menina negra na literatura contemporânea.

Em primeiro lugar, avalia-se a variedade das temáticas do conjunto dos livros, e nesse aspecto o item aventuras está em 78 obras e $26 \%$ do total, saindo na frente de identidade e diferença, presente em 49 obras e 16\%. Enfoca-se também a temática do cotidiano da criança, em 42 obras, representando 14\%. A cultura africana está presente em 19 obras, totalizando $6 \%$.

A autoria masculina sai em disparada, ou seja, 57\% de autores homens e 38\% para autoras mulheres. Ferreira (2008) avalia que há também a autoria mista homem e mulher, mas não mulher-mulher. Desfazendo o que afirma o senso comum, foi constatado que há mais obras nas quais o texto sobrepuja a ilustração do que o esperado. E há mais mulheres ilustradoras do que homens.

Em relação à espécie de personagens, os tipos humanos somam 53\%, os tipos animais $14 \%$ e objeto, $4 \%$, seguido de tipos fantásticos, com objeto místico, vegetal e inseto. O tipo de narrativa em terceira pessoa corresponde a $75 \%$ e em primeira pessoa $21 \%$, aproximadamente. Outro aspecto valioso é o espaço de circulação das personagens. No espaço privado, as mulheres igualam-se aos homens, isto é, $26 \%$ das obras tratam disso. No espaço público circulam $40 \%$ dos homens contra $5 \%$ das mulheres.

Em relação à posição da narrativa por sexo, em $26 \%$ das obras o sexo feminino protagoniza e $17 \%$ são coadjuvantes. Em contrapartida, o protagonismo masculino lidera: são 68 obras, bem como ocupa a posição de coadjuvante, que está presente em 26 obras. A faixa etária das personagens também é considerada, e mais de $40 \%$ é de representação

\footnotetext{
${ }^{18}$ Texto publicado em http://hdl.handle.net/6335.
} 
de adultos e $19 \%$ de crianças na faixa de 0-12 anos. Por sua vez, na tabela específica para sexo da infância, os meninos estão em $12 \%$ e as meninas em $9 \%$.

Duas décadas é o tempo que separa a realização das citadas pesquisas. Embora constate Ferreira (2008) que a autoria ainda é de maioria branca e masculina, o fortalecimento da temática sobre cultura africana, identidade e diferença já permite refletir sobre a questão sugerida por Rosemberg (1985) no que se diz respeito à necessidade de se redimensionar a polaridade da relação dominante-dominado na produção literária. Mas a dominação masculina ainda é preocupante.

É senso comum a dúvida se a vida imita a arte ou a arte imita a vida. Se a arte imita a vida, ela reflete o processo de invisibilidade que a sociedade imprime à pessoa negra, embora se recuse a admitir. A pesquisadora Regina Dalcastagnè ${ }^{19}$, ao empreender a pesquisa de 258 romances contemporâneos, com o "foco na representação de grupos marginalizados na arte", observa que a grande maioria das personagens são homens, brancos e de classe média.

A presença de negros e negras também é destacada na pesquisa. $\mathrm{E}$ isso equivale a uma ínfima representação na temática da narrativa brasileira contemporânea. Importa também lembrar que, no universo desses personagens negros, a maioria pertence à classe baixa. Ainda, negros e mulheres quase não têm voz no romance brasileiro contemporâneo.

As três pesquisas apontam para a mesma necessidade: dar voz para grupos minoritários. Então, não se trata somente em limitar a questão da representatividade em respeito às peculiaridades do outro que se quer evidenciar ou valorizar. Não se trata apenas de falar por alguém, com sugere Barthes. A questão se complexifica a partir do rompimento com o silêncio, e pela reivindicação e conquista do espaço de fala.

Outros caminhos devem ser delimitados e perseguidos para a conquista desse espaço. A representação é um espaço de voz onde a palavra participa de vários contextos ou de verdades contingentes. No entanto, a voz autoral negra já se faz ouvir. Em que espaço a voz da mulher negra está circunscrita? A resposta para esta questão permitiria muitas outras questões. Todavia, Showalter, ao advertir sobre a instabilidade do terreno por onde se calca a crítica feminista, afirma que é um terreno selvagem. Ela constata que o discurso da mulher é duplo, de duas vozes, simultaneamente dentro e fora da tradição masculina.

Nas intersecções dos círculos de Ardener, as vozes femininas procuram penetração, ocupação e rompimento de fronteiras, como propõe Showalter. No entanto,

\footnotetext{
${ }^{19}$ Ver: Regina Dalcastagnè (2002). Uma voz ao sol: representação e legitimidade na narrativa brasileira contemporânea. Estudos de literatura brasileira contemporânea. Brasilia. n. 20, p. 33-77.
} 
espaços interseccionados "pertencem" à autoria feminina branca. Onde se situaria a voz autoral da mulher negra? É possível que esteja além do circunscrito. Então, o modelo de Ardener, ao revelar que a escrita da mulher está simultaneamente presente em duas tradições, denuncia outras estruturas silenciadas na estrutura dominante, como a escrita da mulher negra.

Magistralmente, Virgínia Wolf cria uma personagem de nome Judite, suposta irmã de Shakespeare para mostrar o modo como a mulher fora enclausurada e cerceado o seu direito de voz. Mesmo brilhante, Judite fica louca enquanto seu irmão brilha livremente. Wolf convoca as mulheres à produção escrita. Dialogando com Norma Telles (2012, p. 67) as mulheres que traíam o estabelecido pela sociedade com suas excentricidades eram as loucas, como na metáfora da louca do sótão. E, lembrando os estudos de Gilbert e Gubar (2000), a escrita da mulher é impregnada pela ansiedade de autoria, pela loucura provocada pela desobediência às normas preestabelecidas. Na contemporaneidade, a convocação e ansiedade se estendem à escritora negra ao contestar os padrões impostos. E, por tal se legitima.

Assim, a emergência de uma escrita diferenciada, não-branca, leva à discussão da emergência da literatura negra ou afrodescendente. Ao conceituar a escrita afro-brasileira, Eduardo de Assis Duarte propõe que ela é um conceito em construção. Ele assume que literatura tem uma cor porque cor remete à "identidade", logo a "valores", que, de uma forma ou de outra, se fazem presentes na linguagem que constrói o texto. Nesse sentido, a literatura afro-brasileira se firma como expressão de um lugar discursivo construído pela visão de mundo historicamente identificada à trajetória vivida entre nós por africanos escravizados e seus descendentes (DUARTE, 2014, p. 11).

Ser um escritor afro-brasileiro depende da cor da pele, basta anunciar o pertencimento e identificação com a comunidade negra? Basta apenas relativizar o discurso do negro e discurso sobre o negro? Para Luíza Lobo, não basta o querer pertencer ou ser negro; a literatura afro-brasileira é aquela "apenas escrita por negros". A autora justifica que mais do que assumir-se negro, é relevante a origem autoral, ou a consciência do local a partir do qual o autor expressa sua visão de mundo.

Que elementos distinguiriam essa literatura afro-brasileira? Para Duarte (2014), os identificadores são: voz autoral afrodescendente explícita ou não no discurso; temas afrobrasileiros; construções linguísticas marcadas por uma afro-brasilidade de tom, ritmo, sintaxe ou sentido. Um projeto de transitividade discursiva, explícito ou não, com vistas ao universo recepcional. Um ponto de vista ou lugar de enunciação política e culturalmente identificado à afrodescendência. 
E ainda: temática, autoria, ponto de vista, a linguagem, público constituem os cinco elementos que auxiliam na identificação da Literatura afro-brasileira, um conceito em construção. Processo. Devir. Dentro e fora da literatura brasileira. Produção que implica redirecionamentos recepcionais e suplementos de sentido à história literária estabelecida. Dentro: utiliza a mesma linguagem e formas de expressão. Fora: não se enquadra no ideal romântico de instituir o advento do espírito nacional. Uma literatura empenhada em edificar uma escritura que seja não apenas a expressão dos afrodescendentes enquanto agentes de cultura e de arte, mas que aponte o etnocentrismo que os exclui do mundo das letras e da própria civilização. Caráter marginal fundado na diferença que questiona e abala a trajetória progressiva e linear de nossa história literária. 
A menina negra diante do espelho 


\title{
3. 1. A escrevivência das negras mãos
}

\begin{abstract}
Após a batalha do dia, as mãos negras tecem, fio a fio, uma renda de crochê. A cada três voltas, amarra uma cor diferente de linha e segue, mais três voltas. Ao final de duas ou três horas de rendado, elas param. A dona constata que o tamanho lhe agrada. Arremata o ponto. E pronto! Terminou mais uma toalha. Depois, debruçada na janela da rua, acende um cigarro, contempla a lua e vê os alunos do curso noturno de alfabetização passarem pela rua. Então, ela sonha: “amanhã mesmo vou me matricular. Escrever deve ser igual a tecer crochê: a agulha é igual ao lápis, desenha os pontos que são qui nem as letras. Pontos emendados são as palavras. Uma toalha é igual a uma história. Então, eu já sou uma escritora, espia meu baú: está lotado de toalhas, colchas, forrinhos..." (Transcrição das palavras de Dona Dezinha).
\end{abstract}

Sim, as portas da literatura estão se abrindo para elas: as mãos escreventes negras. Não por piedade ou medo, mas por reconhecimento e conquista. Mesmo marcada pela ansiedade de autoria lembrada por Norma Telles, as escritoras negras de literatura infanto-juvenil estão fazendo acontecer, no alvorecer do século XXI, a visibilidade de obras da literatura afro-brasileira.

Para a crocheteira "Dezinha ${ }^{20 ",}$, a escrita está presente no momento da tessitura de seus artesanatos. É um complexo emaranhado de pontos, correntes, voltas, espaços e cores. Enquanto tece, sonha. As mãos negras da artesã, calejadas, depois de um dia exaustivo de costura, sonha sonhos possíveis, cotidianos, mas plenos de significação.

Da mesma forma, as artesãs de textos infanto-juvenis tecem contos repletos de histórias vividas no seio do seu lugar de pertencimento. Essas autoras-tecelãs negras são mediadoras de mundos que se interceptam ou de mundos paralelos. Assim, escritura e experiência são os esteios que identificam uma literatura marcada por obstáculos como a literatura afro-brasileira. A experiência é relacional, modulada pelo meio, representa o lado de dentro e, através dela, define-se o lado de pertencimento, o lugar de fala. E este implica os resultados das experiências e o como o outro é visto.

Esse lugar de enunciação da mulher é representativo em sua produção cultural. Há uma frase muito divulgada de Simone de Beauvoir que é: Ninguém nasce mulher, torna$s e$. Esta frase demonstra, entre outras questões, que a mulher não é um fruto biológico ou ato da natureza. A mulher é um construto social, um dado cultural. As mudanças e rupturas com sistemas hegemônicos impactam a identidade cultural, de modo que a identidade é formada e transformada continuamente em relação às formas pelos quais

\footnotetext{
${ }^{20}$ Dona Dezinha é uma representante das griots na minha comunidade. Crocheteira, bordadeira, costureira e guardiã da memória de sua família.
} 
somos representados ou interpelados nos sistemas culturais que nos rodeiam (HALL, 1997, p. 13).

Ao falar de um lugar sem pertencimento, a mulher não projeta seus medos e desejos. É o caso das personagens femininas na literatura escrita por homens: as projeções dos desejos e dos medos pertencem ao escritor. É uma experiência vicária. A escrita vicária é de algum modo essencialista. Cabe à escritora romper com esse sistema, descontruir por dentro e mudar paradigmas.

Todavia, a escrita de mulheres negras comunga com o que apontam os estudos multiculturais ao partir da ideia de muitos centros e, consequentemente, muitas periferias. A escrita feminina é marcada pelo jogo das presenças e ausências. É também a escrita a partir de um olhar específico, a "escrevivência". E essa, para Conceição

Evaristo, é o estatuto reivindicado. As mulheres negras, tendo ou não "um teto todo seu", devem lutar. E a luta se dará pela escrita.

As escritoras negras contemporâneas reivindicaram para si o estatuto da escrevivência. E, como herdeiras de Maria Firmina, Auta de Souza, Carolina Maria de Jesus e outras, dão à lume suas obras, como afirma a própria Firmina no prefácio de sua obra Úrsula. Ao tecer seus textos, as escritoras afrodescendentes interconectam raça, etnia, classe e gênero. Como concluiu Conceição Evaristo (2013) ${ }^{21}$ : “A escrevivência é autorrepresentação de um corpo vivido em sua própria escrita. É contar histórias não para ninar a casa grande mas para incomodar".

A esse respeito, salienta Sônia Beatriz dos Santos $(2007)^{22}$ :

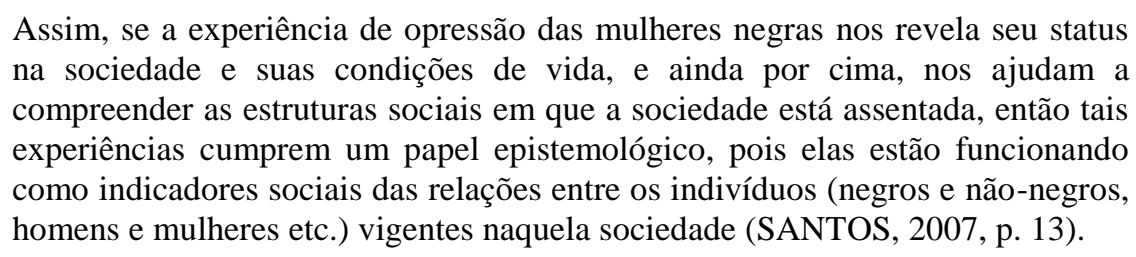

Esse trecho foi retirado dos estudos de Santos (2007) sobre a organização social e política do que ela denominou "feminismo negro diaspórico", citado aqui por fazer uma ponte entre a "escrevivência" de Conceição Evaristo e os estudos de Eduardo de Duarte citados anteriormente. Ou seja, ao escrever, a mulher negra porta consigo todo esse cabedal de tradição que revela as suas marcas de pertencimento. E, ao mesmo tempo, a

\footnotetext{
${ }^{21}$ Palavras oriundas de palestra de Conceição Evaristo na Universidade de Brasília, em $1^{\text {o }}$ de novembro de 2013. Parte de evento do Grupo de Estudos em Literatura Brasileira Contemporânea (GELBC).

${ }^{22}$ Niterói, v. 8, n. 1, p. 11-26, 2ºm. 2007. Disponível em: soniabsantos@ mail.utexas.edu
} 
escrita negra se legitima pela peculiaridade de sua autoria, bem como, no dizer de Eduardo de Assis Duarte (2014), pelo "ponto de vista que dá o tom de sua visão de mundo". Do lugar de onde fala, denuncia. Isto é, a assunção de um ponto de vista de manifesto contra qualquer processo de assimilação cultural, imposta como via de expressão única. E, continua Duarte (2014, p. 32): "a perspectiva afroidentificada, ao superar o discurso do colonizador, configura-se como discurso da diferença”"

Além dos elementos da temática, da autoria e ponto de vista, Duarte (2014, p. 2938) indica o público e a linguagem como fatores que contribuem na configuração de um texto da literatura afro-brasileira. A temática, como já dito, "resgata a história do povo negro na diáspora brasileira", bem como reverte em denúncia dos processos de escravidão e suas consequências. Por sua vez, a situação da linguagem é tenuamente complicada: não rompe com a fruição e estética, mas deve ir além e expressar valores éticos, culturais, políticos e ideológicos. Trata-se, portanto, de um discurso "afroidentificado que objetiva uma nova ordem simbólica".

Isto posto, pode-se pensar em uma escrevivência afroidentificada de mulheres negras produtoras de literatura infantil contemporânea. Como diz Tânia Lima (2009, p. 170), griots são as cultivadoras de textos que se deslocam de um ponto a outro, portando a oralidade, suporte fundamental em seus discursos. "Griots" ou “dieli" são abordados nos estudos de A. Hampaté Bâ (2010, p. 193), que dialoga com tais definições e acrescenta: são "trovadores" ou "menestréis" que animam o público através da música, da lírica, histórias, contos e recreações populares, ligadas ou não a uma família.

Aos "griots" ou "dieli", embora divididos em grupos diferenciais, thes é conferido um status social especial. Desse modo, Nilma Lino Gomes, Heloísa Pires Lima e Silvyane A. Diouf, podem ser consideradas griots, genealogistas, historiadores ou poetas por comporem um grupo de aguerridas escritoras que cumprem o papel da resistência e se ocupam em alargar o campo da literatura infantil, tendo em vista a discussão da construção da identidade negra a partir da infância da menina negra.

Norma Telles (1992) afirma que: “Os silêncios cercavam e cercam o patrimônio cultural das mulheres. Cada nova geração precisa refazer os passos e retomar os caminhos" (TELLES, 1992, p. 50). As autoras, tecelãs e griots, aqui tratadas, reivindicaram para si, não com obrigação, mas com certa devoção, o papel social da resistência e luta pelos direitos humanos, pela busca do reconhecimento da pessoa negra na sociedade.

De que lugar fala cada uma dessas autoras? De quais artefatos culturais lançam mão na construção de seu pertencimento étnico-racial? Pela luta que empreendem para 
assegurar aos grupos marginalizados o seu espaço de voz, essas autoras falam de um lugar legítimo. Neste sentido, Nilma Lino Gomes mineira, educadora, atuante na esfera política e em sua trajetória contribuiu, entre outros, para a instituição da Lei 10.639 de janeiro de 2003, que torna obrigatório o estudo da cultura afro brasileira nas escolas públicas (como já citamos ao longo do texto). O primeiro trabalho ficcional da intrépida autora é Betina, publicado em 2009.

Por sua vez, a gaúcha Heloísa Pires Lima, que é educadora, antropóloga e escritora, encantou-se pela literatura a partir do momento em que percebeu a carência de personagens negras ou sua inadequação no uso das letras, nos diversos gêneros. Deste modo, observa-se que a temática mais evidenciada em suas obras é a da valorização da cultura negra através da construção da identidade de crianças e de adolescentes. Então, suas duas obras aqui apropriadas são: $O$ espelho dourado, publicada em 2003, e Histórias da Preta, publicada em 1998.

E, em terceiro lugar, insere-se nesse contexto de análise afroidentificada a escrita de Sylviane A. Diouf, de pai senegalês e mãe francesa. Autora, professora, engajada em movimentos na Europa, na África, preocupa-se, como historiadora, em evidenciar a história e a cultura dos povos africanos, embora o seu nascimento seja francês. O olhar sobre as culturas africanas vai além do jeito ocidental de enxergar o resto do mundo. Desta forma, revela um modo peculiar em apresentar o humano no seu espaço multicultural.

Sua obra As tranças de Bintou, foi inicialmente publicada nos EUA em 2001, com versão francesa em 2003. No Brasil, foi publicada em 2004. Essa reconhecida obra representa um momento importante para a vida da autora, principalmente por ter sido, ao que parece, um marco ao registrar a infância e a cultura africana na ficção.

Escrever-viver são as ferramentas de que as autoras lançam mão para a construção de referenciais da menina negra, em busca da identificação e localização de seu pertencimento. Partindo da ótica da temática, as narrativas que se seguem procuram costurar os elos da africanidade a partir da representação dos traços culturais que evidenciam a civilidade do povo africano como postura de resistência ao imaginário de povo sem passado que se instituiu em várias partes do mundo e, em especial, na sociedade brasileira. 


\title{
3. 2. A água, o espelho
}

Para Gaston Bachelard (1998, p. 199): “A água tem também vozes indiretas. A natureza repercute ecos ontológicos. De todos os elementos, a água é o mais fiel espelho das vozes". E essa profunda definição sobre a água dialoga com a força da ancestralidade negra como alegoria ${ }^{23}$ presente nos textos de escrita afro-brasileira. É possível "ler" o elemento água como um elo ou um campo fecundante de história e cultura.

O posicionamento de Bachelard indica que a água possui uma dimensão plurissignificativa e dialoga, por uma linha tênue, com os estudos de Marcelo C. Nunes e Rafael Alves (2009, p. 37). Presente nos rituais de umbanda, a simbologia da água está voltada para a criação, compõe a presença do "Princípio do Branco", que é onde toda a criação está presente, ou a ausência e sua complementaridade. Com a água e com o barro, Omi e Omã, Oxalá modelam todos os seres.

O elemento água é definido no dicionário dos símbolos como: "o signo da superfície". A simbologia da água apresenta um aspecto complexo e dual: ao mesmo tempo que é um conjunto de massa líquida, contém os corpos sólidos. Neste sentido, Cirlot (1984) assevera que

\begin{abstract}
por esta causa, os alquimistas denominavam "água" ao mercúrio no primeiro estágio da transformação e, por analogia, ao corpo fluídrico do homem, interpretado pela psicologia atual como símbolo do inconsciente, quer dizer, da parte informal, dinâmica, causante, feminina, do espírito. Das águas e do inconsciente universal sugere tudo o que é vivente, como da mãe. As águas significam o retorno ao pré-formal, com seu duplo sentido de morte e dissolução, mas também de renascimento e nova circulação, pois a imersão multiplica o potencial da vida (CIRLOT, 1984, p. 62).
\end{abstract}

A superfície transparente da água é uma tênue e cristalina camada, que reflete, espelha e capta o mundo circundante. E também duplica. O mundo das águas é também a pátria onde a morte e a vida interagem. Para Bachelard; "é a verdadeira matéria da morte bem feminina”. Essa conceituação sobre as águas e sua capacidade de espelhamento, e do espelho como objeto do realismo-maravilhoso, está representada na literatura infantil de todos os tempos.

Em vários contos infantis, o espelho aparece como uma personagem importante, geralmente aliado a uma antagonista. É o caso do espelho da Madrasta de Branca de

\footnotetext{
${ }^{23}$ Tomei como base para entendimento do termo alegoria o estudo de Massaud Moisés, em Dicionário de termos literários, 2013, p. 14. "Alegoria é uma figura de expressão que consiste numa proposição de duplo sentido, um sentido literal e um sentido espiritual, por meio do qual se apresenta um pensamento sob a imagem de outro".
} 
Neve. Em Alice no País do Espelho, a narrativa do realismo-maravilhoso de Lewis Carroll liga-se ao nonsense (sem sentido) vitoriano. A personagem Alice está em sua sala de estar e resolve atravessar o espelho que se encontra sobre a lareira. O que ela encontra por trás do espelho é um mundo alterado, cheio de possibilidades de aventuras.

Assim, na literatura infantil clássica, o espelho é mais que um elemento dos apólogos. O espelho é também um personagem importante na narrativa. Ora é a voz da consciência, ora um portal que dá acesso a mundos fantásticos. De qualquer forma, o espelho pode significar uma cumplicidade, um parceiro que se alia à personagem em suas vilanias. O espelho pode ser também uma espécie de oráculo, ao indicar ou sugerir a tomada de decisão de sua proprietária, que em geral é a antagonista no texto.

Em $O$ espelho dourado ${ }^{24}$, a sequência das imagens transporta o interlocutor para dentro de uma narrativa fantástica e mítica. E dialoga com a simbologia das águas superiores e inferiores, estudadas por Cirlot (1984, p. 65) ao tratar do processo da chuva como involução e da evaporação como evolução, "com a intervenção do elemento fogo como modificador das águas". Nas figuras 1 e 2, surgem dois caminhos: um em tom vermelho escuro e o outro em amarelo ouro. Em princípio, eles remetem à ilustração de dois rios sobrepostos e antagônicos: superior e inferior, claro e escuro; bem como o espaço superior e o inferior.
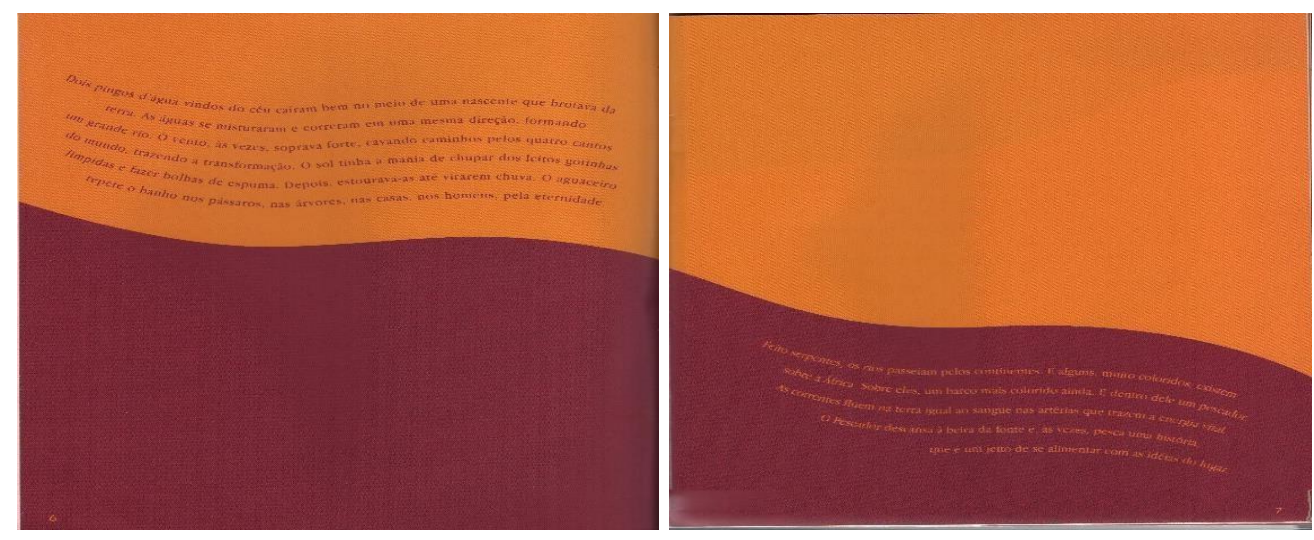

Figuras 1 e 2: o rio do Pescador e as águas de Nyame, em $O$ espelho dourado, 2003, p. 6 e 7.

No entanto, os versos impressos no espaço superior narram o momento exato da criação das águas. Tudo começa por "dois pingos" que caem do céu e começam a obra de criar pelos "quatro cantos do mundo". Os versos constroem a imagem do ciclo das águas, mas também da formação dos rios e de tudo que possa se mover sobre eles.

A partir do momento que a narrativa ocupa o espaço inferior da página, os rios são comparados às "serpentes" que "passeiam pelos continentes". Intervém na narrativa uma

\footnotetext{
${ }^{24}$ Texto de Heloísa Pires Lima.
} 
personagem, um elemento humano, que parece se distanciar no tempo do momento da criação dos rios, e surge depois. E, como sugere Duarte (2014, p. 25), o conto de Pires alude ao "mito da etnia achanti ${ }^{25}$ da criação do homem".

A presença do elemento humano que fica à beira da fonte para "pescar" algumas histórias, "que é um jeito de se alimentar com as ideias do lugar", devolve o leitor desde um espaço onírico para a realidade. A construção da intriga se dá pela narrativa verbal e pela não verbal. Percebe-se que o elemento "água" é bem representado nas duas narrativas. Então, esta pode ser a pista para preencherem-se os vazios na narrativa, isto é: a importância do elemento água como um traço ancestral e criador.

Consequentemente, por esta obra é possível observar que a "ansiedade" de autoria presente no texto de Heloísa Lima Pires repousa em uma escrita afro-brasileira que busca conectar-se com as mitologias africanas para estabelecer um elo, uma ponte de significados. O que decorre desse elo é a construção de uma rede de histórias que atraem o interlocutor para dentro da leitura da oralidade da qual as ancestralidades africanas se constituem.

A narrativa de $O$ espelho dourado se dá em terceira pessoa, e sugere que a construção da intriga se faz sobre dois espaços-tempos diferenciados: o passado e o presente. E, para tal, a linguagem visual vai tecendo uma narrativa paralela. Assim, as primeiras imagens (ver figura 1 e 2) do texto são dois espaços em movimento, que se opõem ou que se refletem. Um claro e um escuro. Significativamente, a escrita é firmada em superfície que sugere um movimento, as palavras flutuam, fluem e afluem em espaços-tempos que seguem paralelos.

A primeira personagem citada é o Pescador. Nas informações paratextuais, o Pescador é um interventor cujo pertencimento ao lugar em que transita é relativo. Ele tem por projeto: percorrer os mares da terra em busca das citadas "ideias do lugar". Esta personagem está estrategicamente colocada para gerar uma tensão de pertencimento: ela vem do passado ou do presente?

No senso comum, a figura do pescador está sempre relacionada a um contador de histórias mirabolantes e duvidosas. De algum modo, o pescador comum funciona como griot $^{26}$, o que oraliza a tradição, o que guarda as histórias, a memória. A fala do pescador

\footnotetext{
${ }^{25}$ Pode ser encontrado como ashanti, axanti e asanti.

${ }^{26}$ Para ampliar o conceito, é preciso recorrer ao que propõe Nei Lopes em Enciclopédia Brasileira da Diáspora Africana sobre griot. Segundo o autor, o termo griot "pertence ao vocabulário franco-africano e foi criado no período colonial e designava o narrador, cantor, cronista e genealogista que pela tradição oral, transmite a história de personagens e famílias importantes às quais, em geral, estaria à serviço (LOPES, 2004, p.310).
} 
é oriunda da oralidade que para, Paul Ricouer (2007, p. 28), é a recorrência da memória ou o ato de trazer para o "presente o que está ausente". Este jogo de ausência é marcadamente presente na literatura infantil afro-brasileira. Deste modo, o narrador de $O$ espelho dourado parece relatar as experiências de duas personagens: a do Pescador, atual, e a da princesa ganense Nyame, ocorrida na dinastia achanti, por volta de 700 a. C.

No decorrer da narrativa, passado e presente se misturam em um espaço repleto de simbologias e de significados. E esta escolha da autora se justifica quando a pretensão é revelar as tradições culturais dos povos africanos. Assim, ao navegar pelas águas das culturas africanas, o navegador flutua por um passado histórico, que vivifica o mito da criação da natureza e do homem.

Então, o espelho das águas percorridas pelo Pescador reflete a memória ancestral. Tanto é que, na narração, esse contato com o passado se dá em vários momentos. O primeiro momento é circunscrito quando o Pescador, estirado sobre a canoa, mira as águas espelhadas do rio: "A canoa quase parava. A brisa, muito leve e doce, acompanhava a calmaria. A superfície das águas refletia um mundo com céu, árvores e tudo o mais". Então, surge a questão que interliga os tempos e os espaços insinuados: "E se houvesse do lado de lá um mundo igual ao que existe do lado de cá?" (LIMA, 2003, p. 8).

A própria metáfora do espelhamento pode ser lida como o instrumento de leitura e entendimento da narrativa. Enquanto o Pescador mergulha em suas interrogações do que pode haver num mundo similar ao dele, Nyame desfazia a sua imagem refletida nas águas escuras do rio. Enquanto o Pescador, livre, devaneia em meio à brisa e a imensidão das águas, a princesa Nyame foi capturada por inimigos e aprisionada entre as matas e o rio Niger.

Há uma recomendação de Ana Mafalda Leite (2012, p. 186) que deve ser lembrada. Ela diz respeito à "interdiscursividade" ${ }^{, 27}$ convocada para o entendimento entre os contextos da oralidade e o estudo das literaturas africanas. Embora a literatura aqui consultada seja afro-brasileira, este termo se ajusta à análise.

A interdiscursividade está expressa em vários momentos na narrativa. Observa-se que para Nyame, ao se encontrar aprisionada e sem saída, o espelho das águas é o elo comunicativo disponível para o acesso à sua avó. A narração dá a informação de que "os mortos habitam um mundo que é a imagem espelhada do mundo dos vivos. Por isso, os

\footnotetext{
27 Apoio-me neste termo "interdiscursividade" como entendimento da rede de relações oriunda dos discursos das diversas Áfricas para analisar os discursos multiculturais decorrentes, as múltiplas vozes de espaços e saberes diferentes.
} 
antepassados não estão exatamente mortos, mas, sim, invisíveis” (PIRES, 2003, p. 9). E este preceito pode ser confirmado nos paratextos no final do livro.

Então, os elementos orais presentes na narrativa apontam para o entrelaçamento dos discursos da ancestralidade. Tais discursos são referenciados pelas águas que espelham um mundo invisível no qual habitam os antepassados, que podem ser acessados por invocação. $\mathrm{O}$ espelho das águas define-se na narrativa como um portal por onde as vozes da memória ancestral entram em contato com o mundo dos visíveis. Como se lê na narração: "Sentada à margem do rio Niger, a jovem pensava em invocar a poderosa avó, a rainha-mãe, que se tornara invisível. Ela, certamente, apareceria em seu sonho, “território" onde vivos e ancestrais podem se encontrar e falar". (PIRES, 2014, p. 9).

De modo superficial, o trecho propõe uma leitura de relação de gênero. A divindade feminina protege a princesa. $\mathrm{O}$ acesso se dá por evocação. $\mathrm{O}$ espelho das águas ora está vazio, ora está ocupado pela presença da avó ou entidade. Essa presença-ausência dialoga com a explicação de Cirlot (1984, p. 239) do espelho como símbolo da "multiplicidade e mobilidade da alma". Ao que parece, os mundos visíveis e invisíveis estão interligados.

No entanto, o encontro entre a avó e a neta somente ocorre em sonhos. O território do sonho é o mundo do real e do possível para as personagens. Nyame implorou que a avó mostrasse o que estava acontecendo ao seu amado e assim foi feito. Como num sonho, a avó fez Nyame entrever a aproximação do amado.

E algo inusitado ocorre na narrativa. Percebe-se que de algum modo Nyame conecta-se ao seu amado em sonho e apanha sua alma e a mergulha em um banho de ouro. Ao realizar este feito, o corpo do seu amado, agora reluzente, tornou-se imbatível, pois todos os perigos lançados em sua direção "batiam e voltavam”. E, após ser "guiado pelos ancestrais", e "pelas batidas do coração de sua amada, encontrou Nyame" (PIRES, 2003, p. 19).

Nyame é uma divindade ou um ser humano? A identidade de Nyame é um enigma no texto. Esta ambiguidade propõe uma variedade de significações para a heroína da história. As imagens narrativas dão pistas que não são lidas com facilidade. É necessário, pois, analisar os aspectos interdiscursivos presentes no texto. Assim, podemos observar que os elementos que acompanham Nyame são seres dotados de brilho; ou seja, as águas e o ouro. Quais as relações desses elementos com a identidade da heroína? É possível classificar Nyame como uma divindade?

A reivindicação na narrativa da identidade de Nyame se justifica pela imagem do ouro que a empodera, tornando-a, de certo modo, transcendente. Na etnia achanti, por 
volta de 700 a.C., produzia-se objetos metalúrgicos através da extração de poderosos metais e, além disso, comercializava-se o ouro. Portanto, "o banho de ouro", "a chuva de ouro em pó", "o cabelo trançado com fios de ouro", "os ornamentos de ouro no vestido de casamento", são estruturas estrategicamente situadas no texto. E essas estruturas coroam a heroína de uma moldura narrativa que a desloca de um mundo real para um mundo fantástico. Cirlot (1984, p. 434) propõe que: “Tudo que é feito de ouro está relacionado a uma função de superioridade".

$\mathrm{Na}$ narrativa, "após anos, desce dos céus um trono de ouro". Essa imagem demonstra a consagração do poder e a riqueza do povo de Nyame. Além dele, outros objetos de ouro são representados na narrativa visual. Dentre eles, encontram-se peixes de ouro, a reprodução de um cavaleiro montado num cavalo que se repete, simulando movimento. Além de objetos geométricos, pingos e ondas, há também a ilustração da união de Nyame com seu guerreiro. O que estas imagens representam?

Para responder essa questão, é importante concordar com Ciça Fittipaldi (2008, p.103) que afirma: "Toda imagem tem uma alguma história para contar. A menor presença formal num determinado espaço já é capaz de produzir fabulação e, portanto, narração. " O trono de ouro é mostrado como símbolo divino. É a certeza da ancestralidade presente e influente na vida cotidiana. Na narração consta que

\begin{abstract}
tempos depois, desceu miraculosamente do céu um trono de ouro maciço. Desde então, acredita-se que o objeto é sagrado - ele é conservado até os dias atuais em um santuário especial. Só que nenhuma pessoa, nem mesmo o rei, tem o direito de nele sentar. Ele é reverenciado para lembrar a união alcançada e aos governantes que dela devem, acima de tudo, cuidar. Só assim, os espíritos ancestrais lhes irão abençoar (PIRES, 2003, p. 19).
\end{abstract}

O trono de ouro pode representar o elo entre os mundos das divindades e mundo dos homens. E também, a certeza da conquista dos antepassados, pois, ao reverenciá-los no presente, o povo terá a compreensão de sua origem, de sua identidade. Esse aspecto inviabiliza a postura de que o povo afro-brasileiro, em sua diáspora, não possui préhistória e tradições culturais.

$\mathrm{O}$ estudo de Lúcia Harumi Borba Chirinos ${ }^{28}$ intitulado Arte e oralidade entre os ashanti: classificação e interpretação dos pesos traz interessantes apontamentos sobre a cultura ashanti. Um desses pontos é a existência dos pesos de ouro que são objetos usados para prender o pó de ouro que era usado no comércio, como espécie de moeda de troca. A

\footnotetext{
${ }^{28}$ Arte e oralidade entre os ashanti: classificação e interpretação dos pesos de ouro. Disponível em: www.arteafricana.usp.br. Texto para comunicação no XI SIICUSP, setembro de 2003. Revisto e adaptado em dezembro de 2004.
} 
pesquisadora expõe que o povo ashanti tinha uma tradição metalúrgica e forjava as pequenas figuras de metal ou os pesos. Esses pesos foram produzidos em vários formatos: animais, vegetais fundidos a partir de um modelo in natura. E, a partir de um modelo de cera: figuras geométricas, figuras animais, antropomórficas, artefatos, cenas/combinações. Elementos como sementes, contas de vidro, ossos, conchas, cerâmica e fragmentos de metal também podiam ser usados como pesos.

Todavia, o que há de mais significativo na questão dos pesos é que são símbolos cosmogônicos da cultura ashanti. E isso se dá porque eles são portadores de uma linguagem oral, plástica e visual e são transmissores de provérbios. Desse modo, os pesos representam a criação da identidade da realeza. Isso implica que a experiência humana é transmitida pelos provérbios sintetizados nos pesos.

O exemplo do provérbio do peso do crocodilo com o bagre é bem significativo. Segundo a pesquisadora, ele exprime que "se o bagre engole algo precioso, ele o faz para seu mestre. " O mestre, no caso, é o crocodilo, por ser um predador natural. Portanto, isso implica que os pesos são representações concretas de noções abstratas.

Curiosamente, os pesos encontrados na narrativa de $O$ espelho dourado podem ser lidos também como provérbios. O projeto de ilustração do livro procurou incluí-los como narrativa visual. Então, esses pesos podem ser considerados como personagens na construção da intriga. Como já citado: pingos, ondas, elementos geométricos, animais são dispostos ao longo do texto. (Ver Figuras 3 e 4),

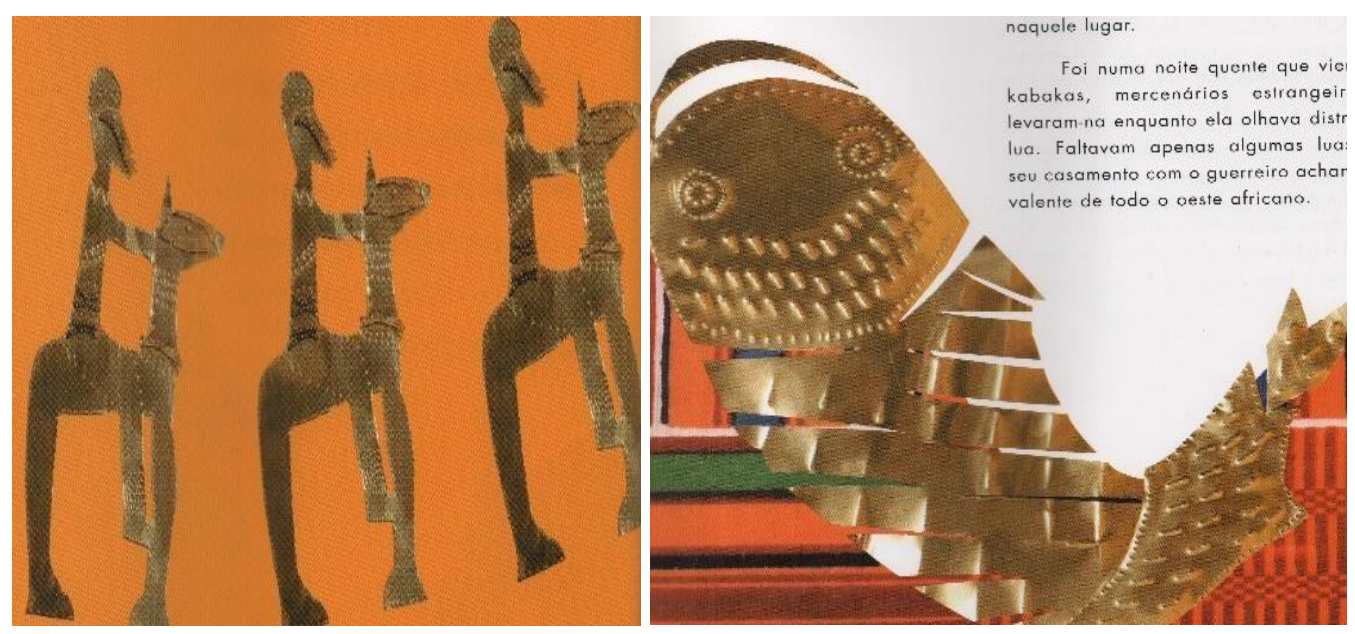

Fig.: 3 e 4 Pesos: Guerreiro em busca de Nyame e O peixe dourado. Em O espelho dourado, de Heloísa Pires Lima, 2003, p. 10 e 12.

A imagem da capa (ver figura 5) é a mesma da página dezoito que é do momento do casamento de Nyame. Ela pode significar a representação de um peso, pois é forjada 
por metal dourado, em alto relevo e contém uma que é o momento do beijo nupcial. Esse beijo pode representar a vitória do amor e a construção de um reino.

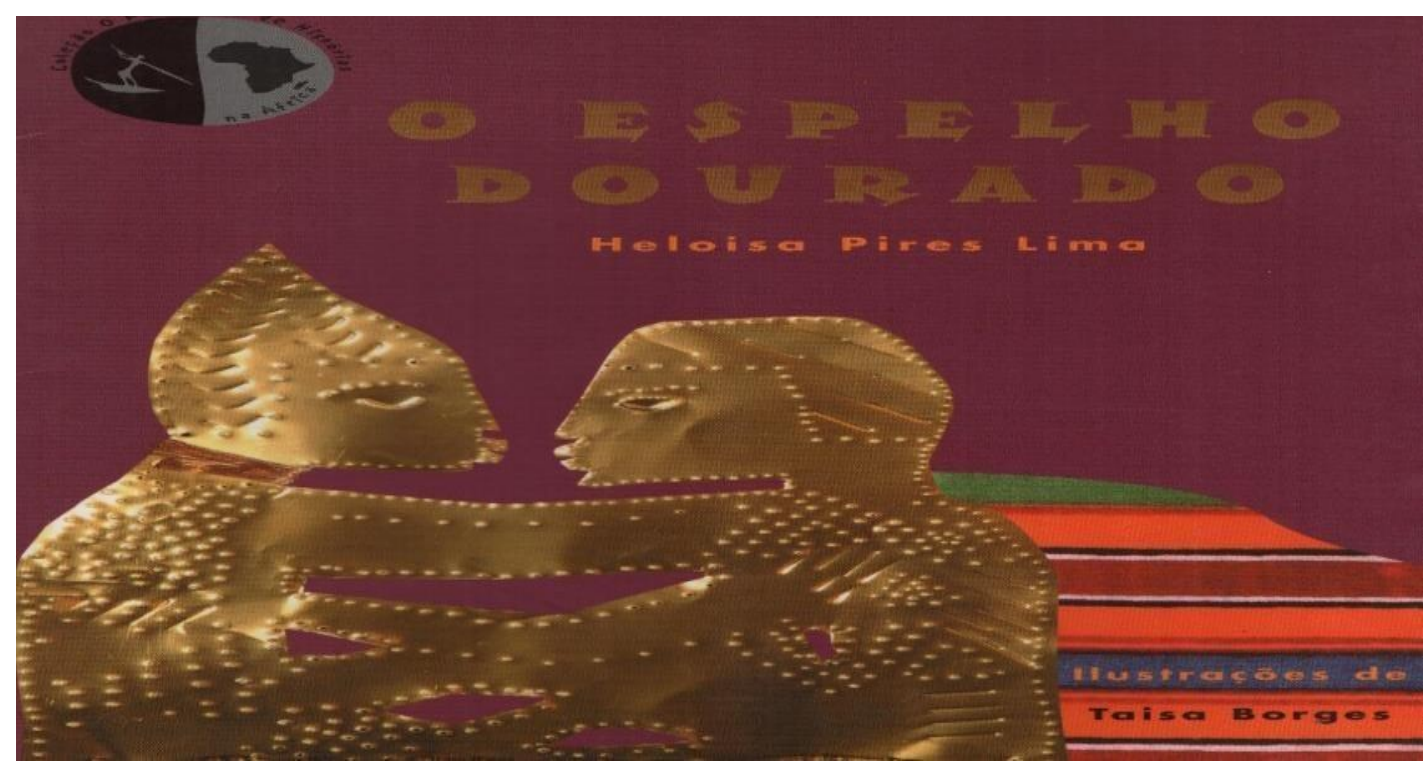

Figura: 5- O casamento de Nyame e o guerreiro, em O Espelho Dourado, 2003, capa e p. 18.

Enfim, essa narrativa está repleta de chaves, e com elas abrem-se as portas das tradições africanas e sugere um olhar plural sobre a sua cultura multimodal. Se em Nyame vê-se a importante representação feminina da criação da natureza, o que se pode pensar sobre a presença do Pescador na narrativa? Em dado momento, surge um "peixe dourado" que aparece e desaparece, misteriosamente. A narração afirma que o "peixe dourado vinha à tona, como querendo dizer alguma coisa" e depois sumia no fundo do rio (PIRES, 2003, p. 10).

Assustado, o Pescador preparou-se para pegá-lo. Então, armou a rede e ficou de prontidão. No momento esperado, atirou a rede ao mar. E, por surpresa, a rede volta vazia e cortada por lâminas afiadas: "Era como se mil espadas tivessem-na cortado ou um grande poder houvesse por ela atravessado" (p. 15). Quem pode ser esse peixe poderoso? Nyame ou uma divindade das águas? Ou Nyame, a possível divindade das águas? Essas propostas estão presentes no texto, através dos ardis e sutilezas da narrativa verbal e não verbal.

Então: “O Pescador parte com a certeza de que havia pescado uma boa história (p. 19) ". O Pescador representa o papel dos testemunhos da tradição oral, os griots. Ele é o elo, o diálogo com o passado. Ao atravessar as águas africanas, arrasta seus mitos, lendas e tradições. Para Barthes (2009, p. 199), “o mito é uma fala, um modo de significação”. 
Essa fala mítica e plena de significações pode se constituir como estratégias narrativas para a representação do universo multicultural da tradição oral africana, numa primeira camada analítica.

No entanto, é preciso refletir sobre o campo de abrangência ou como essa narrativa, visual e verbalmente, impacta a construção da identidade negra feminina. Em princípio, a narrativa se aproxima da necessidade de rompimento com as marcas de racismo: de alguma maneira a escravidão de Nyame dialoga com a questão da diáspora negra ou a representa. Isso implica identificar o aspecto multidisplinar presente na narrativa.

$\mathrm{Na}$ abrangência multidisciplinar da narrativa está representada a marca da ancestralidade autorizada na personagem Nyame. E isso está caracterizado pelo modo como essa personagem foi construída, oriunda da tradição oral africana, por esse motivo, repleta de simbologias e de significados. A construção dessa personagem complexa e ambígua exerce fascínio no leitor. E, em termos autorais, dialoga com Góes (1984, p. 117), pois Nyame aproxima-se mais de um arquétipo ou "a caracterização de uma idéia universal" do que de um personagem tipo.

Por sua complexidade e ambiguidade, Nyame encerra uma proposta de representação de difícil assimilação e tradução. Como identificá-la?

\section{3. Betina: uma narrativa de formação}

Para a assunção da construção da identidade da menina negra a partir dos discursos narrativos, mister se faz recorrer ao que afirma Vera Maria Tietzmann Silva (2009):

\footnotetext{
No tema da identidade, a autoimagem também inclui o tamanho. Crescer envolve passagem, sofrimento, abandono do mundo infantil e enfrentamento das responsabilidades do mundo adulto. $\mathrm{O}$ medo de crescer e de sair da tutela dos pais tem fundas raízes no imaginário, e as narrativas infantis dão forma essa ansiedade (TIETZMANN, 2009, p. 56).
}

Esta passagem dá indicadores do que ocorre na diegese de Betina. Para tanto, se se comparar a personagem Nyame a Betina em relação à sua capacidade representativa, dois modelos de criança negra são, prontamente, diferenciados: um modelo idealizado e outro representado no cotidiano. Não desconsiderando as possibilidades de leitura das tradições traduzidas na narrativa $O$ espelho dourado, sua protagonista Nyame é uma princesa que vive em um espaço de difícil acesso, aprisionada e isolada, e não se sabe que 
tipo de relações com a vida concreta podem ser realizadas. Betina, por sua vez, apresenta um cotidiano real.

$\mathrm{Na}$ narrativa, a personagem realiza todas as atividades que uma menina faz: brinca de pular corda com suas amigas, de boneca, de roda. Ela frequenta uma escola, tem uma família presente. Curiosamente, embora a narrativa $O$ espelho dourado mostre um final feliz, de casamento, em Betina o cotidiano é o fio condutor de sua trajetória enquanto ser humano.

Como representação da menina negra, a construção da identidade de Betina se contrapõe ao corpo abjeto proposto por Butler (2002), citado anteriormente nesse texto.

O sujeito descentrado e fragmentado citado por Hall (2003), ou mesmo o sujeito "fraturado" em oposição a um sujeito "unificado, central e solar" estudado por Luís Costa Lima (2000, p. 84), dialogam com a identidade do sujeito menina negra. E isto ocorre porque a visão que se quer formar da menina negra, na contemporaneidade, parte da necessidade de situá-la como ser pertencente e atuante no espaço social que ocupa, um sujeito

Essas características delegadas ao sujeito menina negra podem classificá-la como um ser em constante evolução, um vir a ser diferenciado daquele modelo negativizado presente no racismo à brasileira, embutido no mito da democracia racial. Assim, pensar o cotidiano da menina negra possibilita redimensionar o modo de sua representação na sociedade.

A representação da menina negra a partir da narrativa Betina, expressa-se no modo como suas experiências enquanto ser humano foram construídas. Como assevera Costa Lima (2000, p. 110), “a representação de um objeto está relacionada à sua experiência”. E esta experiência relaciona-se ao cotidiano estudado por Michel de Certeau (2014). O autor de $A$ invenção do cotidiano reflete, de maneira inaugural, como a cultura em uma sociedade se constitui por movimentação e relativização das noções de verdades estabelecidas. Este trabalho se constituiu a partir de pesquisa realizada pelo autor entre 1974 a 1978, e narra os eventos culturais ordinários, corriqueiros. Eventos que são, simultaneamente, movidos pelas relações sociais resistentes.

Então, em Betina, as experiências cotidianas podem ser consideradas elementos que confrontam o modo como a menina negra vêm constantemente sendo representada. A valorização da vida diária e doméstica da menina negra pode redimensionar o modo de ver a pessoa negra na sociedade, não mais como passivo consumidor da cultura dominante. 
Ou seja, dialogando com Certeau (2014, p. 38), “o cotidiano se inventa com mil maneiras de caça não autorizada". Assim, pensar a importância da vida cotidiana de Betina implica ressignificar seu espaço social e, no diálogo com Certeau que propõe uma "combinatória de operações que compõe uma cultura e exumação dos modelos de ação", perceber o modo de agir nos espaços sociais para esta conquista.

A valorização dos eventos da vida de Betina é um possível indício para reverter o modo como a menina negra ordinariamente é representada nos espaços midiáticos e culturais. Embora a narrativa seja construída em terceira pessoa, há uma preocupação em evidenciar um espaço considerável de diálogo entre Betina e sua avó. Tomando aqui o conceito de "tática" usada por Certeau ("a tática só tem por lugar o outro" (p. 45)), as relações sociais e afetivas que a protagonista Betina estabelece com os grupos sociais dos quais participa (amigos da rua, escola, família, comunidade) dão um tom diferenciado à conquista de um espaço ressignificado de representação étnica.

Deste modo, em suas "práticas de espaço", Betina é uma menina negra que brinca, tem uma boneca preta, anda muito limpa e bem vestida, cabelos sempre alinhados e bonitos, tem uma família, tem amigos, é participativa na escola. Reage com firmeza à manifestação de preconceitos que lhe imputam na escola. É possível que a narrativa Betina represente um meio de redimensionamento do olhar sobre a pessoa negra, cujos conceitos se deslocam de passivos para sujeitos pertencentes e atuantes na sociedade. Isto resulta que a identidade negra é um construto "social, histórico, cultural e plural", como assevera Gomes (2005, p. 42).

Na narrativa, a vida da protagonista Betina é retratada da infância à fase adulta. E, como adulta, ela é um sujeito autoconfiante e conectado na relação com o outro. Esta atitude autoral em dar autonomia e voz a uma protagonista negra pode sugerir uma quebra de paradigmas. E essa quebra constitui-se na ponta de um novelo que deve ser desenrolado e articula-se com a indagação: Sob quais perspectivas narrativas Betina é uma narrativa de formação?

Para Massaud Moisés (2013, p. 57), um romance de formação é uma "modalidade de romance", tipicamente alemã, que "gira em torno das experiências que sofrem as personagens durantes anos de formação ou de educação, rumo da maturidade, fundada na ideia de que a juventude é a parte mais significativa da vida. " $E$, ao que consta, esse é um conceito de romance de formação tradicional.

Como classifica Bakhtin (2011, p. 219), um personagem do romance de formação ou de "educação" contrapõe-se àquele personagem fixo, pronto, do romance tradicional. No romance de formação, a produção da imagem de homem varia e ganha significado no 
enredo. Para tal, a categoria tempo se "interioriza dentro do homem". Assim, no entendimento de Bakhtin: "A formação do homem pode, entretanto, ser muito diversificada. Tudo depende do grau de assimilação do tempo histórico real”.

Em seus estudos, Bakhtin indica cinco tipos de romance de formação. O primeiro é o tipo cíclico-idílico baseado nas fases ou nas idades do homem, cuja período de formação pode se dar da infância à juventude, da fase adulta à velhice. O segundo tipo está também ligado à idade do homem, mas de modo menos estreito. Diz respeito ao idealismo que ocorre da fase juvenil à adulta. Trajetória que oscila entre o ceticismo e resignação. A representação da vida se dá como aprendizado, como experiência, como escola.

Há também o tipo de romance de formação biográfico que, independente da questão cíclica, a formação se dá como resultado das condições de vida e de acontecimentos. Como assume Bakhtin, "a formação da vida-destino se funde com a formação do próprio homem" (BAKHTIN, 2011, p. 221). O quarto tipo apontado é o que se constitui no elemento puramente didático-pedagógico, ou seja, o processo educacional propriamente dito. No quinto modelo, por sua vez, "a formação do homem se apresenta em indissolúvel relação com a formação histórica”. Esse modelo sobrepuja os demais porque a formação do homem está condicionada à relação história-realidade-necessidade. Há uma projeção dessa formação desvelando-se no tempo, atrelada ao caráter cronotópico.

A perspectiva que se abre no quinto tipo de romance de formação em Bakhtin diz respeito à relação mudança homem-mundo. Ou seja, se nos primeiros quatro tipos a transformação do homem tinha por fundo um mundo estático e pronto, as mudanças poderiam ser consideradas acessórias. Não havia uma interferência substancial no mundo da personagem. No quinto tipo, por sua vez, a mudança baseia-se na relação de interdependência homem-mundo, cuja transformação se dá concomitantemente.

Como essas características narrativas ecoam em Betina? Em que aspectos a obra se aproxima ou se afasta de uma narrativa de formação? Por ser um conto infantil, Betina traz um encantamento visual que expõe uma infância suave, protegida, prolongando-se até a fase adulta.

Então, Betina é uma protagonista negra que tem toda sua vida desvelada pela narração. Sua luta pela afirmação da pessoa negra começa na infância. Assim, um primeiro aspecto a ser considerado aqui é o tempo histórico real. O tempo é um tema bem relatado em Betina, quer pela narrativa visual, quer pela narrativa escrita. As modalidades do romance de formação levantadas por Bakthin se exemplificam em Betina: pode ser notado que cada fase de sua vida é valorizada. 
A infância de Betina é marcada por momentos idílicos representados nas brincadeiras de rua, nas cirandas e cordas, nos cuidados da avó, na ida para a escola. A capa do livro, observada na figura 6 , mostra uma menina sentada, com brinquedos ao redor, segurando uma boneca preta. Ao que parece, a menina negra representada está sentada em um chão de um cômodo de sua casa, com a cabeça inclinada parecendo estar em contato com mais alguém que não está na cena. A cena mostra a infância, momento especial na formação da pessoa humana. E a infância de Betina é criteriosamente representada: a menina tem momentos de brincadeiras com amigas, tem um bom convívio com a família, é uma criança que aprende a se valorizar como pessoa negra desde cedo.

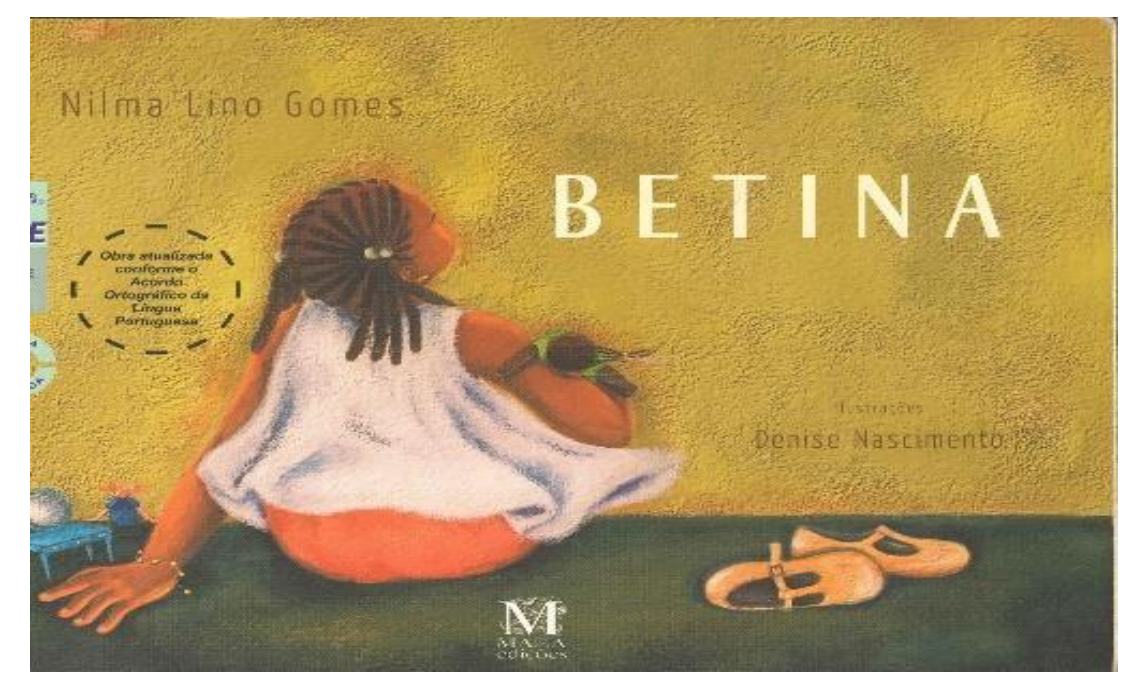

Figura 6: Capa de Betina (2009). Menina negra sentada. Suas tranças, seus brinquedos, seus sapatos.

Cada fase da vida da vida humana traz aprendizagens específicas. A infância de Betina encerra um princípio de formação importante para a protagonista em sua construção como sujeito pertencente a uma comunidade. A narrativa, enquanto exemplo de modelo cíclico-idílico, procurou enfatizar cada fase da vida da protagonista. Com isso, é possível observar uma trajetória de crescimento da menina em adolescente, depois em adulta. E o principal: a constatação de que a construção da identidade de Betina como pessoa negra começa na infância.

A marcação do espaço-tempo na narrativa de Betina é construída com a contação dos fatos que ornaram a infância da menina. Na narrativa, a protagonista aparece brincando no espaço fora de casa e, logo nas primeiras páginas, canções e cirandas são cantadas, enquanto a avó observa o modo de deslocamento da menina, que pula corda feliz, na medida em que o tempo passa. Essa cena pode ser observada nas páginas iniciais até a página 5, conforme figuras 7 e 8 abaixo: 

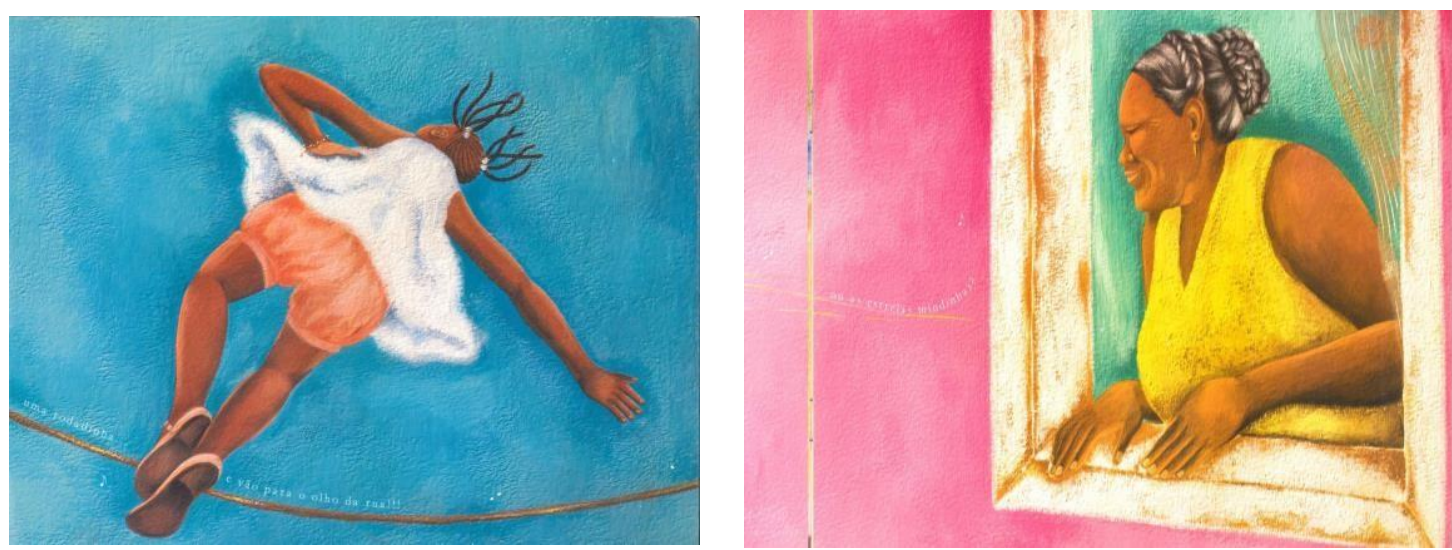

Fig.: 7e 8 Fonte: Denise Nascimento: Betina brincando no quintal, enquanto sua avó observa.

Como apontado anteriormente, Leite (2012, p. 166) propõe o termo "interdiscursividade" para expressar, entre outros, as variantes na literatura africana no trato ou contexto da oralidade. E essa condição é observada na produção da diegese em estudo, quando a narradora de Betina imprime um tom prismático ao construir o texto, tanto verbal quanto visual. E de acordo como o Minidicionário Aurélio: o dicionário da língua portuguesa (2004, p. 654), "prismático" pode ser compreendido por: "sólido em forma de prisma, geralmente triangular, feito de vidro ou de outra substância transparente, usado para dispersar ou refratar a luz."

Então, na diegese de Betina, os discursos verbais e visuais interagem e produzem uma narrativa repleta de significações, evidenciado, inclusive, na técnica usada na ilustração que remete à técnica pastel. A técnica do pastel, segundo Ray Smith (2008, p. 77), consiste em uso de "pigmento de pouca aderência, e embora utilizada desde os séculos XV e XVI, "atingiu seu estatuto no século XVIII pela maestria de Edgard Degas".

Segundo Smith (2008, p. 77), a característica principal do pastel é a sua pouca aderência às superfícies, necessitando de manejos para tentar sustentar o pigmento. Essa peculiaridade do pastel, ou seja, sua efemeridade, pode ser observada na construção da narrativa visual em Betina, cujas figuras transbordam-se em transparência, cor e luz. Assim, entre outros aspectos, a narrativa colore-se de tradição e de tempo, de interior e de intimidade.

Para Martine Joly (2003, p. 59), a imagem é um modo de "interceder no mundo". E um dos exemplos dessa intercessão na narrativa visual em questão é a presença da roupa branca e esvoaçante de Betina. A suavidade proposta pelo traçado da técnica empregada promove a sensação de leveza e de fugacidade e, ao mesmo tempo, de profundidade. A perspectiva que se cria com a imagem da figura 7 é de gradação de claridades, de textura, de cor, e evidencia contextos em que os espaços e as personagens se desenvolvem. 
Ou seja, como meio de fixação do mundo real onde desfilam os acontecimentos, os discursos visuais e verbais se complementam e reforçam a ideia de tempo vivido na infância de Betina. Esse entrecruzar de conto fabular e realidade é expresso na narrativa através de sentenças que revelam o passado de Betina. Ao contar o modo como aconteceu a infância de Betina, há indícios de que a narração procura apresentar um espaço e tempo de educação, crescimento e de felicidade em família como meio favorável para a construção de uma identidade negra feminina. A infância bem resolvida de Betina, conforme ilustra a figura 8, expõe a preocupação em projetar nesta fase da vida, os compromissos da pessoa negra.

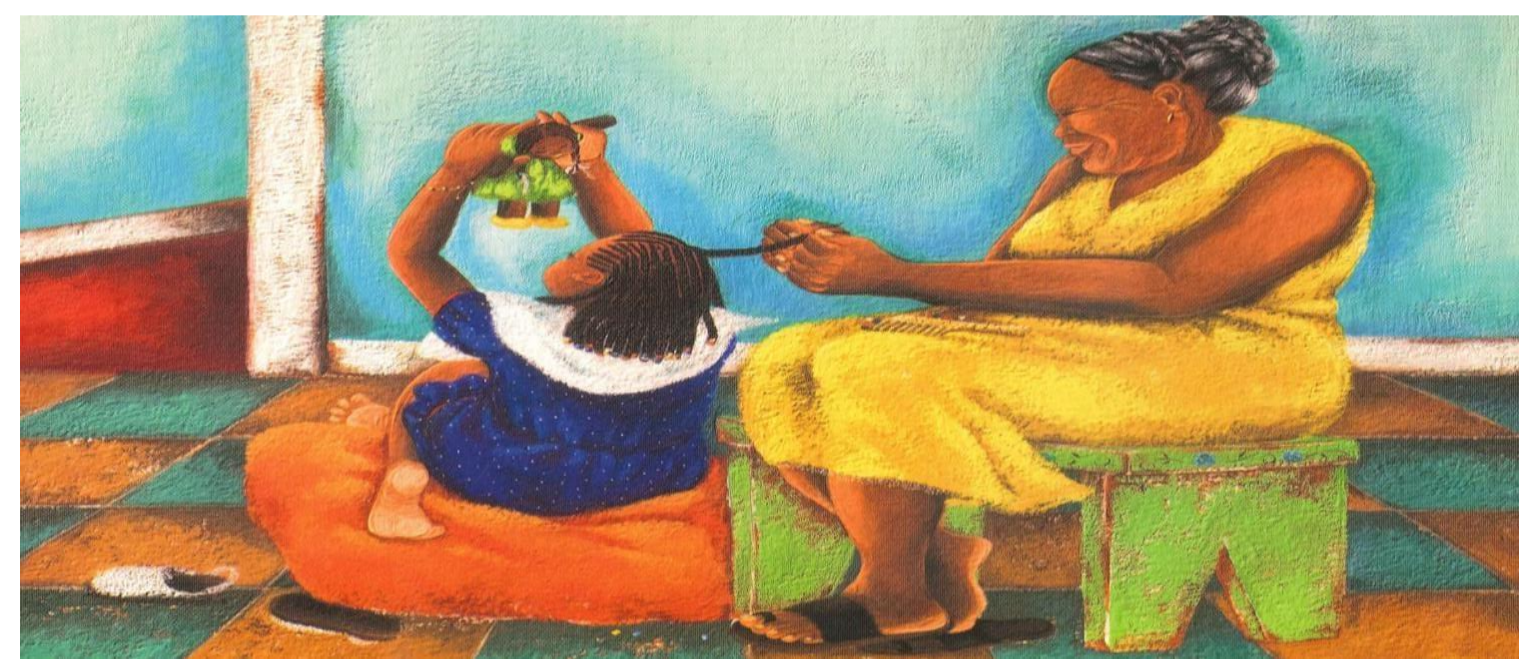

Fig: 9. Fonte Denise Nascimento. O ritual de trançar os cabelos, em Betina (2009, p. 7).

Com isso, são anunciados em diálogos bem marcados entre avó e neta, momentos de aprendizado: “- Ai! Ui! Vó! - reclamava a menina” E sua avó respondia: “- Que é isso, Betina? Estou penteando com tanto cuidado!” (GOMES, 2008, p. 6).

Então, o ato de identificar em Betina aspectos da narrativa de formação, começaria por observar que toda a preocupação do eu enunciador está em fixar as fases da vida da protagonista, valorizando a experiência de cada idade ou fase de sua vida. Desse modo, elementos do romance de formação se apresentam na narrativa Betina, que aborda as fases da vida da protagonista, revelando a pessoa idealista que ela se tornou, a aprendizagem que a vida lhe proporcionou, no cumprimento do seu destino.

Desse modo, cita-se o pronunciamento do eu enunciador:

O dia de fazer penteado novo era especial. A avó tirava as tranças ou o coque antigos, lavava o cabelo da neta, passava creme para desembaraçar, desembaraçava, lavava de novo e secava com a toalha. Nessa última etapa, o cabelo já não tinha mais creme. Depois de todas essas etapas, a avó sentavase em um banquinho, colocava uma almofada para Betina sentar-se no chão, 
jogava uma toalha sobre os ombros da menina, dividia o cabelo em mechas e ia desembaraçando, penteando e trançando uma a uma, com rapidez incrível (GOMES, 2008, p. 6).

A infância, o espaço cíclico da primeira formação de Betina, é marcada pela relação de aprendizagem avó-neta. E isto se nos revela vários discursos lúdicos representados no momento da trançagem dos cabelos, quando a ancestralidade se reverte em tema de aprendizagem, na tradição oral cultuada pela avó: "Enquanto trançava, avó e neta conversavam, cantavam e contavam histórias. Era tanta falação, tanta gargalhada que o tempo voava! E, no final, o resultado era um conjunto de tranças tão artisticamente realizadas que mais parecia uma renda" (GOMES, 2008, p. 6).

Com esta inserção, o eu enunciador fixa os acontecimentos da vida de Betina, que delimitam o espaço de aprendizagem da cultura africana e promovem a noção de pertencimento da pessoa negra. Esse aprendizado se prolonga, ao que parece, durante a fase da adolescência até quando a protagonista alcança a vida adulta. E esses fatos são bem demarcados na narrativa verbo-visual. $\mathrm{O}$ eu enunciador desfila os eventos da história de Betina através de uma linha temporal linear.

Vida e morte são presentes na narrativa de um modo especial. As ilustrações propõem um olhar para o infinito, para o futuro. Vida e morte se cruzam na linha do horizonte. A passagem do tempo está escrita no crescimento físico da personagem que se contrapõe ao declínio do corpo da avó. E, mais uma vez, a avó ensina à neta que a morte é o encontro com os ancestrais. Nas palavras da narração, o tempo escorre: "Sua avó foi envelhecendo... envelhecendo" (GOMES, 2008, p. 12).

Nas palavras da avó, a adolescente Betina aprende que em um lugar chamado África viveram seus ancestrais e, que após a morte, esperarão por elas. Esses ancestrais "deixaram ensinamentos e muitas histórias de luta" (p. 12). As palavras da avó são os ensinamentos que germinam na protagonista o idealismo pela luta, a "força e a coragem" e a certeza que os ancestrais estão representados em suas vidas.

Ao que parece, com lirismo e determinação, a intenção autoral flui nas páginas para, entre outros, demonstrar que a pessoa negra possui uma tradição forte e inspiradora. Aqui encontramos também o processo educacional propriamente dito e a evidência da relação história-realidade. Assim, na figura adiante, quando avó e neta procuram desvendar os mistérios da vida, pássaros sobrevoam o céu azul e as suas cabeças. A textura impressa em suas asas remete ao geometrismo que orna os tecidos africanos. Essa sutileza da narrativa visual instiga à reflexão de que a aprendizagem da menina negra 
Betina está envolvida em um complexo esquema de tradição cultural e repertório sóciohistórico.

Tendo em vista o cumprimento dos aspectos que aproximam Betina da narrativa de formação, é possível que as figuras 10 e 11, abaixo, deem essa visão. E, ainda, propõem a reflexão quanto ao desenvolvimento e o aprendizado da protagonista, que se seguiu da adolescência à vida adulta.
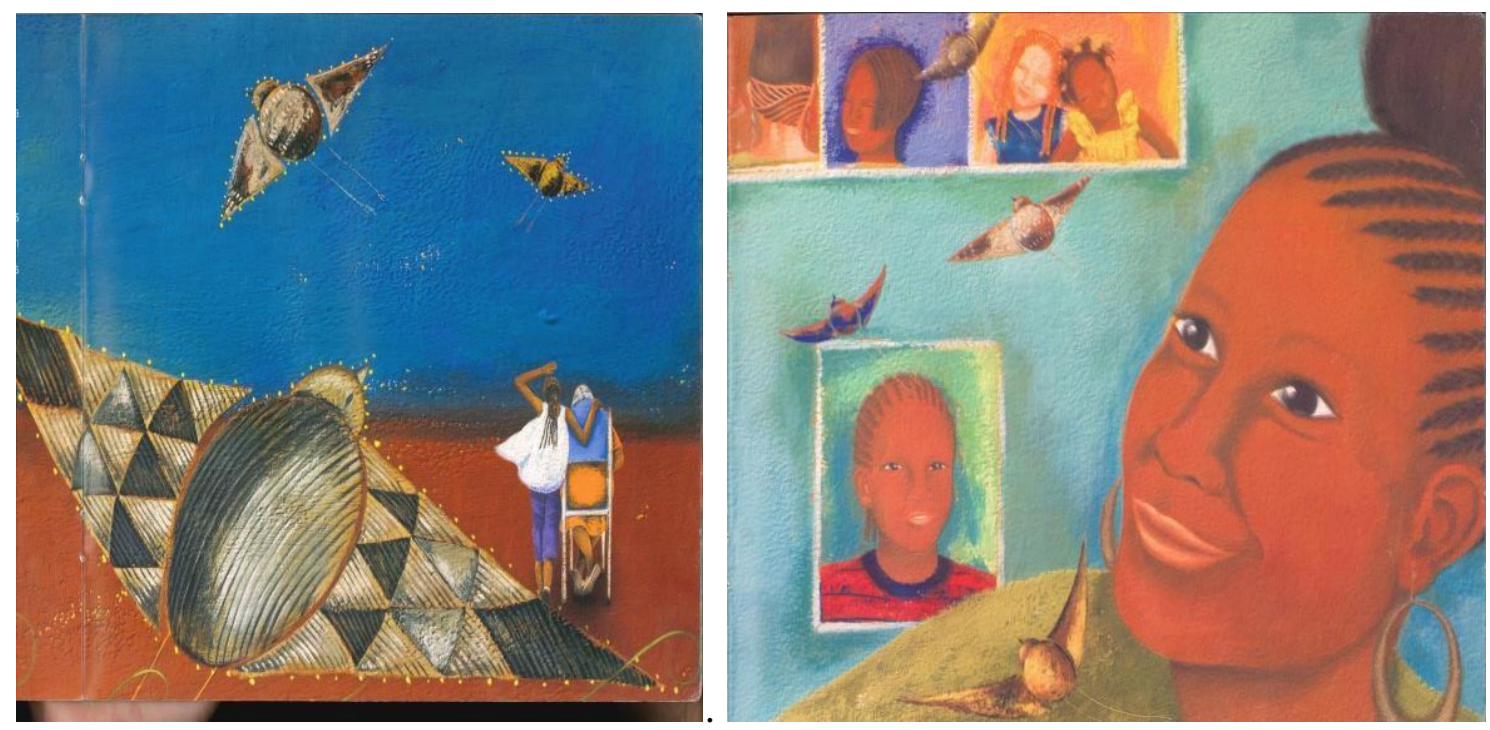

Fig.: 10. Figura: 10 A passagem do tempo. Figura: 11. Betina adulta, em Betina, p. 15 e 19.

Segundo informações do eu enunciador, "o tempo voou mais um pouco. Daquele dia em diante, a avó passou a ensinar Betina a trançar". E finaliza: "Mas, além de crescer, a nossa Betina-menina-trançadeira virou Betina-mulher-cabeleireira" (p. 18). Portanto, ao pensar na trajetória de Betina enquanto pessoa negra, pertencente a um grupo étnico, é possível concordar que na narrativa a protagonista promoveu o seu desenvolvimento como pessoa, como sujeito. E que essa transformação se deu pelas experiências formadoras vivenciadas por Betina.

Não obstante as linhas gerais usadas como parâmetro para o entendimento da narrativa de formação, segundo o pensamento de Bahktin, é possível dialogar com algumas estudiosas do romance de formação, e observar outros aspectos que aproximam o conto infantil Betina à narrativa de formação. Isto inclui os estudos de $\operatorname{Maas}^{29} \mathrm{e}$ de Schwantes $(2010)^{28}$.

\footnotetext{
${ }^{29}$ MAAS, Wilma Patricia Marzari Dinardo. O cânone mínimo: o Bildungsroman na história da literatura. UNESP, 2000.
} 
Desse modo, importa citar o que afirma Schwantes (2010, p. 105) sobre a dificuldade de se conceituar o romance de formação. Segundo a pesquisadora, o motivo principal, deve-se de algum modo, à sua própria especificidade que é a de "narrativizar o processo de formação de um (a) protagonista", devido, entre outros, às especificidades de cada grupo social. Isto porque, segundo a mesma: "o meio social no qual o romance de formação é escrito e recebido tem um impacto muito grande sobre sua escritura".

A narrativa em estudo, Betina, partilha dessa definição por construir uma personagem duplamente significativa: é mulher e menina. É fácil concordar que o conto Betina, dessa forma, aproxima-se das narrativas de formação. A temática desenvolvida e o tipo de personagem representado impactam também pela subversão ao modelo tradicional de romance de formação. Isto inclui pensar, inclusive, como argumenta Schwantes, sobre a lista de eventos que compõe um romance de formação, conforme os estudos de Dilthey, citados por ela (SCHWANTES, 2010, p. 106).

A "lista" representa eventos que, somados, permitem ao protagonista "conhecer as regras da sociedade". Entre os componentes da lista, destaca-se a possibilidade de viagem para expansão do conhecimento e a presença de um mentor, que no caso do romance de formação tradicional, segundo a pesquisadora, "trata-se de um homem mais velho que toma o protagonista sob sua proteção" (SCHWANTES, 2010, p. 107).

Em Betina, igualmente, aparecem esses elementos ressaltados no romance de formação tradicional. Quando criança, adolescente e jovem, Betina teve como mentora a sua avó. A avó representou o elo entre a menina com sua ancestralidade, com sua tradição e culturas africanas. Em uma das palestras que a protagonista, quando adulta, profere, ela responde a uma ouvinte que aprendeu a trançar os cabelos com sua avó: - "Foi minha avó - e seus olhos se encheram de saudade" (GOMES, 2008, p. 20).

Dialeticamente, Betina se aproxima da narrativa de formação e, com a mesma intensidade, a subverte. Isto se dá porque, ao se tratar de protagonista feminina, complexificam-se as características do gênero. Assim, é possível concordar com Schwantes (2010, p. 107) e afirmar que Betina, como protagonista, "trafega duplamente na contramão da tradição".

E essa subversão em Betina está visualizada, principalmente, por se tratar da formação de protagonista mulher, negra e, ainda, menina. Ao mesmo tempo, observa-se o esforço da narradora em promover a construção de uma personagem negra importante na

${ }^{28}$ SCHWANTES, Cíntia. Narrativas de formação contemporânea: uma questão de gênero.São Paulo, 2010. 
sociedade da qual faz parte. Essa escolha na narrativa é, antes de tudo, política. A esse respeito, é preciso lembrar o que propõe Maas (2000) quanto à apropriação do Bildungsroman à brasileira, na crítica feminista.

Como acontece nas narrativas de formação pós-coloniais, que contemplam o processo de formação de personagens que fazem parte de uma minoria, Betina subverte o gênero tanto formal quanto ideologicamente. Essa projeção de Betina-menina-negra em Betina-mulher-negra rompe com a marcação ideológica da construção da identidade da pessoa negra na sociedade brasileira, embutida no mito da democracia racial.

\subsection{Meninas negras diante dos "espelhos sociais"}

\footnotetext{
"E eis o preto reabilitado, "alerta no posto de comando", governando o mundo com sua intuição, o preto restaurado, reunido, reivindicado, assumido, e é um preto, não, não é o preto, alertando as antenas fecundas do mundo, bem plantado na cena do mundo, borrifando o mundo com sua potência poética, "poroso a todos os suspiros do mundo" (FANON, 2008, p. 117).
}

O posicionamento de Fanon parece dialogar com o que expõe Gomes (2005, p. 41) ao tratar da construção da identidade negra não como algo natural, porém, ligada ao modo de ser no mundo e com os outros. A identidade envolve a questão cultural, sóciopolítica e histórica que implica a construção de uma rede de relações e de referências.

Essa pessoa "preta, restaurada, reunida, reivindicada e assumida" projeta-se como o produto elaborado pela sociedade. A literatura infantil contemporânea tem buscado cumprir este papel de produção de outras maneiras de ser negro na sociedade atual. Em Betina, por exemplo, a formação da protagonista de mesmo nome é narrada em terceira pessoa por um eu enunciador que parece torcer pela personagem e é capaz de dar espaço à voz da personagem através do discurso indireto livre. A ação da protagonista é contada no passado, ora perfeito, ora imperfeito. O tempo é marcado pela linguagem verbal e visual e convida o leitor a participar da trajetória e crescimento da personagem.

Há um fato curioso na narrativa visual em Betina: a única vez no texto todo ela aparece de frente, o que na verdade aparece é o seu reflexo no espelho. Desde a capa, quando ela aparece de costas e em todas as páginas de sua infância e adolescência, ela está sempre em deslocamento para o infinito, visualizando o futuro. E o que se evidencia de seu corpo são as tranças. O cabelo de Betina marca, assim, seu crescimento físico, as fases de sua vida.

Esse momento de magia, quando a menina realmente surge frontalmente (ver figura 12, abaixo) para o público é narrado da seguinte forma: 
Quando a avó terminava o penteado, Betina dava um pulo e corria para o espelho. Ela sempre gostava do que via. Do outro lado do espelho, sorria para ela uma menina negra, com dois olhos grandes e pretos como jabuticabas, um rosto redondo e bochechas salientes, cheia de trancinhas com bolinhas coloridas nas pontas (GOMES, 2008, p. 8).

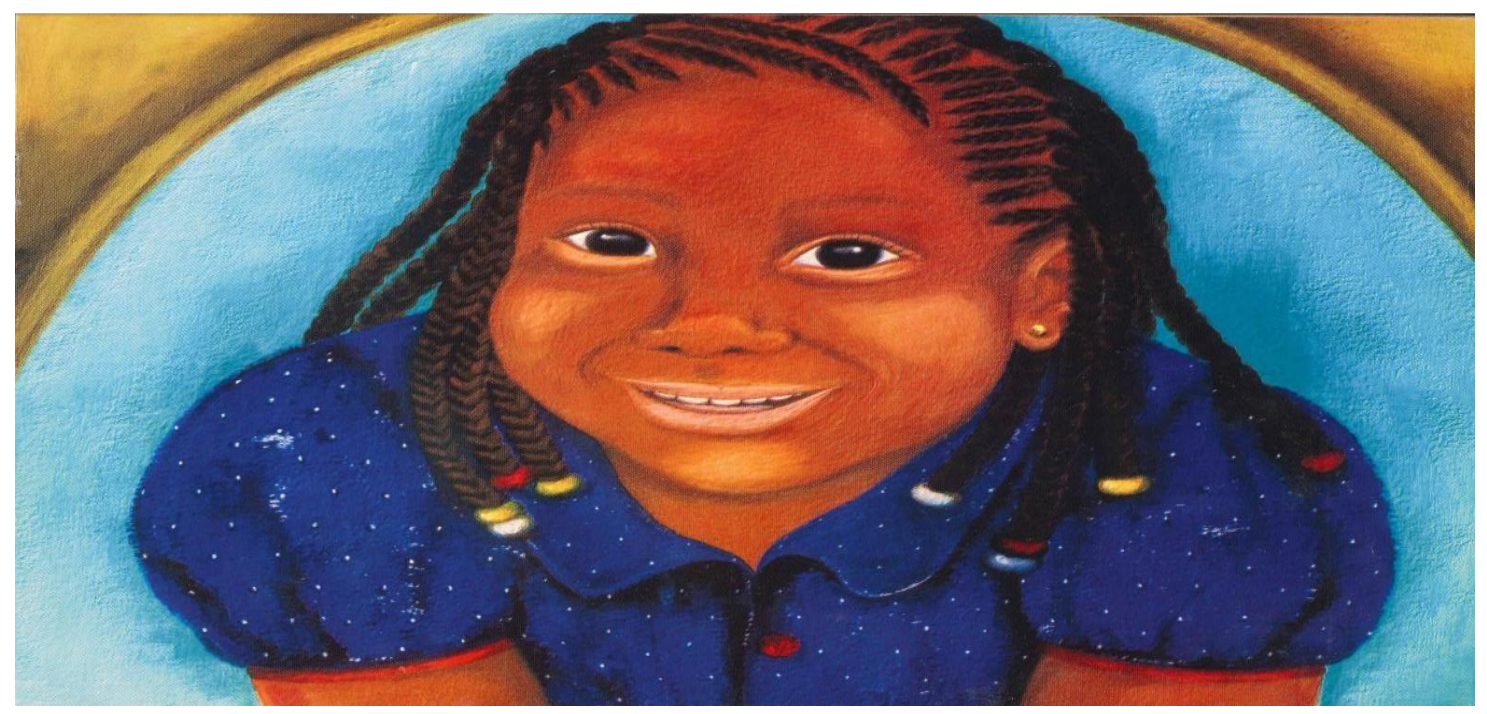

Figura 12: Betina diante do espelho. Em Betina, de Nilma Lino Gomes, 2008, p. 9.

Em suas pesquisas, Hauser (2009, p. 39) estuda o tema da representação frontal da figura humana na arte egípcia antiga. Nesse sentido, ele assevera que "a parte superior vista de frente é a expressão de uma relação definida e direta com o observador", um modo de dirigir-se ao público. Esse traço cultural da tradição egípcia pode ser identificado no momento que Betina tem seu rosto refletido no espelho. $O$ que surge desse afrontamento é a possibilidade de comunicação e de interação. Isso implica que a linguagem visual imprime um tom de interlocução com o "leitor" de Betina.

E nesse processo de comunicação, a possível mensagem veiculada giraria em torno da afirmação da pessoa negra pelo que ela é. E isso vai além de suas características físicas, fenotípicas e biológicas. A construção da identidade da menina negra é uma construção interdiscursiva e multicultural. A identidade é uma construção social e política.

Essa constatação identitária dentro da narrativa de Betina dialoga com o que afirma Fittipaldi (2008) quanto à "capacidade da imagem visual de trabalhar com as imagens mentais suscitadas na expressão poética literária”. A ilustradora-autora reflete com isso que as imagens narrativas podem propor outros elementos que redimensionam os significados do texto escrito, não superando-o, "mas adere a ele com a intenção de colaborar na sua percepção, amplificar suas vozes” (FITTIPALDI, 2008, p. 104). 
Essas características narrativas estão presentes em todas as imagens na obra. Como nos contos clássicos, a imagem de menina que surge no espelho remete ao processo de ressurgir de outros espaços não concretos, dando a entender que a menina reaparece, ou surge como uma fada. Todavia, a imagem da menina no espelho parece cumprir outros papéis: a afirmação de ser pessoa negra. E essa afirmação se confirma na narração: "e ela gostava do que via”. Embora criança, Betina "cruza fronteiras”, como afirma Silva (2014, p. 88) para subverter processos de fixação de identidades. E, como discute Shohat e Stam (2006, p. 289), o rompimento com estereótipos exige que grupos minoritários reivindiquem o direito por "representações justas".

Representar, justamente, a pessoa negra implica em escolhas éticas e políticas. Necessita, entre outros, uma valorização de todos os elementos visuais ou não que, dialeticamente, excluem e incluem a pessoa negra. Dessa forma, o cabelo é um complexo elemento identitário da pessoa negra. E este discurso complexo do cabelo, em Betina é um elemento de grande importância para a sua identificação. Pelo cabelo, ela se insere no mundo social como pessoa negra. O cabelo é, por assim dizer, a representação de um discurso político que a protagonista profere nos grupos sociais dos quais participa: escola, rua, salão de beleza. A reivindicação pelo discurso do penteado afro é um elo entre histórias e culturas, entre passado e presente.

Em seu trabalho "Sem perder a raiz", Nilma Lino Gomes contabiliza os resultados de sua pesquisa realizada em salões de beleza, ouvindo homens e mulheres. O objeto da pesquisadora é a manipulação do cabelo crespo. Este objeto foi escolhido por ser representativo na militância que o observa com certa desconfiança. Ou seja, o cabelo crespo é um ponto nevrálgico nas discussões do movimento negro.

No entanto, a pesquisadora se propôs com sua pesquisa a "saber como essas pessoas pensam a questão da estética corporal negra em um país que, apesar da miscigenação racial e cultural, ainda se apoia em um imaginário que prima por um ideal de beleza europeu e branco" (GOMES, 2008, p. 23). O cabelo de Betina conduz a narrativa toda. A imagem que surge no espelho se configura como o produto de uma tensão entre uma imagem social construída pela via da subordinação e o confronto pela reconstrução de uma autoimagem positiva da pessoa negra.

A trançagem dos fios evidencia a concepção sobre o fazer político na narrativa Betina, bem como implica na reflexão sobre a raiz dos cabelos, que permite ou sustenta a produção dos penteados. A raiz é o sustentáculo, o que permanece. Essa metáfora dialoga com construção da menina negra como sujeito da pós-modernidade e sua consciência quanto às suas raízes africanas. Sujeito pertencente ou que se quer pertencente e 
articulado. Esta postura está contemplada nas seguintes palavras de Gomes (2008), quando essa afirma,

"na realidade o conteúdo político da relação do negro e da negra com o cabelo e com o corpo não pode ser visto simplesmente no tipo de penteado adotado nem somente na intervenção estética utilizada, mas na articulação desses com a localização do negro no contexto histórico, social, cultural e racial” (GOMES, 2008, p. 179)

A imagem social que surge de Betina possui um efeito de subversão e enfrentamento. Paralela a essa imagem, é preciso incluir, nessa discussão, a imagem de outra protagonista: Bintou, ${ }^{30}$ (Ver figura 13). A narradora é também a protagonista da história, ela reflete logo no início: "Meu nome é Bintou, e meu sonho é ter tranças. Meu cabelo é curto e crespo. Meu cabelo é bobo e sem graça. Tudo que tenho são quatro birotes na cabeça" (DIOUF, 2005, p. 5).

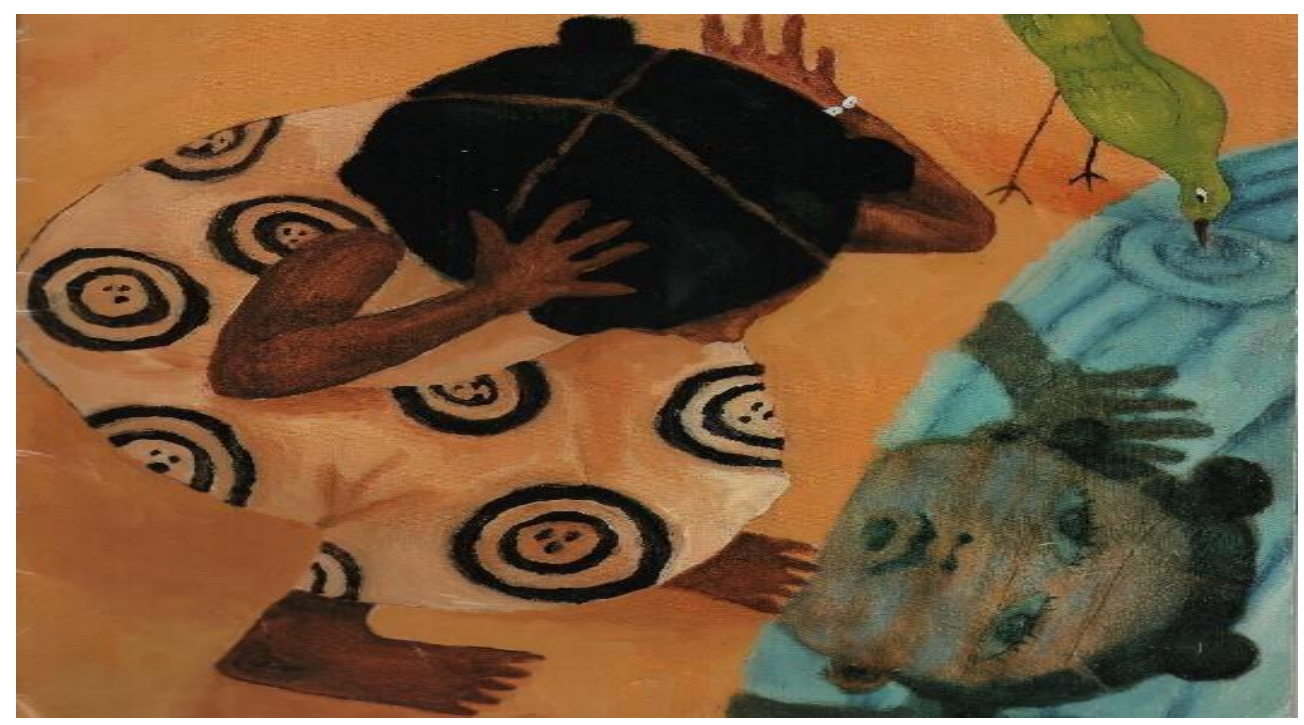

Figura:13. Bintou se vê nos espelhos das águas. Em As tranças de Bintou, 2005, p. 5.

Entre Bintou e Betina há um largo espaço de diferenças e aproximações. E isso se dá por se tratar de projetos autorais oriundos de situações culturais marcadamente diferentes. No entanto, Betina e Bintou são personagens que discutem elementos simbólicos e paradigmáticos da construção da identidade negra: cabelo e corpo.

Ney Lopes (2004, p. 148) conceitua o vocábulo "cabelo" paralelamente ao conceito de identidade negra. E esta relação se justifica por encerrar uma trajetória de construção e afirmação identitárias. Esta caminhada é refletida por Lopes ao explicar que

${ }^{30} \mathrm{O}$ texto, As tranças de Bintou, foi escolhido para compor o corpus por indicar, entre outros, que o movimento de inclusão corrente atualmente no Brasil encontra ressonância em outros países. Ademais, a obra é distribuída pelo PNBE às escolas públicas.( Grifos meus). 
o cabelo negro tem como adjetivos os termos "pixaim", "carapinha" ou "ruim" em comparação ao cabelo "bom" dos não negros. Ele propõe que "o cabelo crespo e lanoso de africanos e descendentes é o principal elemento definidor de sua etnicidade".

A trajetória de afirmação identitária ou africanidade da pessoa negra pelo cabelo na visão de Lopes (2004), passa pela questão surgida na década de 1910, que foi a questão norte americana do alisamento dos cabelos como meio de pertencimento. Essa postura ganhou o cinema e o mundo. No entanto, a onda "black power" (black is beautiful) da década de 1970 redimensionou esse comportamento: os negros passaram a ter orgulho de seus cabelos encarapinhados e volumosos. Lopes (2004) afirma que, na década de 1990, o alisamento dos cabelos ressurge com outras conotações, outras técnicas. O uso dessas novas técnicas não se baseia no sentimento de inferioridade, mas pela necessidade de afirmação da diferença.

Essa reflexão de Lopes (2004) dialoga com a pesquisa de Gomes (2006) citada anteriormente. No entanto, ao refletir sobre o comportamento de pessoas negras nos espaços dos salões de beleza, a pesquisadora analisa que os salões étnicos são espaços sociais que "saem na contramão de imagens e leituras negativas sobre o negro". Isso por recriar um padrão estético negro que inclui, do mesmo lado, o respeito pelas tradições étnicas e a valorização de tecnologias modernas. A autora reflete que as tentativas de recriar um padrão estético de beleza negra, muitas vezes, acabam por copiar uma estética branca.

No entanto, assevera Gomes (2006), a questão é bem mais que ambígua. O que se deve levar em consideração, segundo ela, não é a cópia de padrões, mas a possibilidade de recriação e de valorização das especificidades e histórias de cada mulher ou homem. E isso ocorre nos espaços dos salões de beleza, que para a pesquisadora, desenvolvem um tipo de relação pautada no diálogo "que destaca e valoriza o cabelo crespo e o corpo negro".

Todavia, a questão da aceitação/rejeição-negação das marcas identitárias: cabelo e corpo vai além de ser ambígua. Tais marcas são subjetivas e propõem uma reflexão aprofundada. Como demonstrado na pesquisa de Gomes (2006), a situação requer um olhar multimodal. O salão de beleza étnico se constitui como espaço político que possibilita, pela leitura de cartazes, imagens e cores, a construção de discursos positivos da autoimagem negra.

A autora propõe que para a reflexão quanto à construção da identidade negra, tendo em vista a sua subjetividade, é preciso o acionamento de uma postura multimodal. É 
preciso articular várias áreas de estudos, inclusive a psicanálise, que contribuiriam para a compreensão deste processo (GOMES, 2006, p. 147).

E essa multimodalidade tem sido, ao que se vê, o caminho evidenciado nas narrativas em estudo, na construção de suas protagonistas. As reflexões que cada narrativa vem propor estão carregadas dessa subjetividade. Essa inquietação em aceitar-rejeitar está representada em Bintou. Ao pensar nas múltiplas significações do elemento "cabelo", é preciso recorrer novamente a Cirlot (1984, p. 131). Para o autor, cabelos são sinônimos de "forças superiores" e de "fertilidade", de "vitalidade" e "alegria de viver".

Enquanto a imagem social de Betina propõe uma pessoa realizada com sua autoimagem, Bintou passa a narrativa querendo compreender por que crianças de sua comunidade somente podem usar "birotes" 31 , muito embora sua avó, como em Betina, ensine a ela que ter tranças é ter responsabilidade e arremata: "Poderá usar tranças no momento adequado" (DIOUF, 2005, p. 9)

Culturalmente, Betina é uma personagem que confronta as imagens negativizadas da pessoa negra. É uma protagonista que propõe essa discussão política, que subverte por sua riqueza. Em As tranças de Bintou, a preocupação da protagonista é a de compreender a sociedade em que está, naturalmente, inserida. É a de saber cumprir as regras sociais, em seu curso rotineiro. Bintou representa a inquietação infantil de saber os porquês, e, embora demonstre tristeza por constatar que terá tranças somente na adolescência, ela é a narradora que projeta o olhar do leitor, como em uma câmera, para dentro de sua comunidade, apresentando, com riqueza de detalhes, a tradição cultural de seu povo.

Em As tranças de Bintou, como em Betina, ter tranças é ser uma pessoa respeitada. Esses comportamentos podem ser lidos como ritos de passagem. É preciso dialogar novamente com Certeau, que afirma: "O espaço é um lugar praticado" (CERTEAU, 2014, p. 184), para compreender que as protagonistas em estudo, ao se deslocarem em seus espaços sociais, promoveram a ampliação do olhar sobre em que "espelhos sociais", parafraseando Gomes (2005, p. 143), a menina negra brasileira tem se olhado, e em quais imagens estão sendo construídas.

Então, se para Bintou, respeitando suas práticas de espaços, ter tranças é estar no espaço familiar, em Betina ter tranças é desafiar, nos espaços da sociedade brasileira, redimensionando o olhar de dentro do próprio negro com relação ao seu corpo e a si mesmo, interagindo com o outro. A imagem das protagonistas é um discurso inesgotável

\footnotetext{
${ }^{31}$ Penteado simples que consiste em dividir o cabelo em quatro partes e fazer uns rolinhos. Por sua natureza, os birotes demandam pouco tempo para elaboração, e dão mais tempos para as brincadeiras infantis. (Grifos meus).
} 
de possibilidades de resgate da ancestralidade como entendimento de que a pessoa negra tem um percurso e uma história longa.

A construção da imagem positiva da menina negra requer esse olhar para trás, para as tradições culturais africanas. Esse papel é cumprido por outra protagonista: a Preta (ver figura 13). Para ampliar o entendimento de como se constrói uma imagem positiva da protagonista menina e negra, os discursos que a Preta, que é a narradora e a protagonista da obra Histórias da Preta, propõe é o de mostrar as Áfricas para o povo brasileiro, e discutir como as Áfricas estão presentes na cultura brasileira.

Essas perspectivas estão representadas nas narrativas híbridas aqui discutidas. $\mathrm{Ou}$ seja, a literatura infantil híbrida, por sua vez, parte do real para introduzir o imaginário. O universo criado é a do realismo mágico, como já abordado (COELHO, 2010, p. 264).

Por sua característica híbrida, as narrativas em estudo buscam romper com questões de estereótipos através da representação de imagens positivas, em oposição ao processo de inferiorização da pessoa negra e de sua cultura. Em As tranças de Bintou, a construção da identidade feminina pode ser observada tanto pela questão da valorização da etnia, quanto nas situações de gênero. E isso se dá na hierarquização e importância da mulher em sua comunidade.

Nesse aspecto, para pertencer ao espaço onde está inserida, Bintou quer se identificar com sua irmã mais velha. Ela desabafa:

\begin{abstract}
Minha irmã, Fatou, usa tranças e é muito bonita. Quando ela me abraça, as miçangas das tranças roçam nas minhas bochechas. Ela me pergunta: "Bintou, por que está chorando? Eu digo: "Eu queria ser bonita como você". "Meninas não usam tranças. Amanhã eu faço novos birotes no seu cabelo." Eu sempre acabo em birotes (DIOUF, 2005, p. 7)
\end{abstract}

Regras e atitudes são táticas relacionadas às práticas de espaço, como lembra Certeau. Essa questão está relacionada ao modo como a comunidade de Bintou propõe as regras sociais e como elas são vivenciadas. Ao mirar-se no espelho, Bintou reflete sobre as formas de pertencer ao grupo de mulheres que ela admira. Ela sabe que para fazer parte dele, ela precisa ter as tais tranças.

Na citação acima, a presença de Fatou é uma das marcas de referencialidade para Bintou, e esta questão vincula-se ao processo de construção de identidade, na proposta da alteridade, da diferença. Ao afirmar "Eu queria ser bonita como você", a narradorapersonagem expressa sua vontade de pertencer ao coletivo de mulheres de sua comunidade, bem como as relações de respeito entre seus pares. Como assegura Silva (2004), há um processo de associação entre a identidade pessoal e a identidade social. Ou 
seja, "a identidade social" é fruto do processo da inter-relação da "identificação do indivíduo".

Bintou observa a reunião das mulheres de sua comunidade "atrás da mangueira", de longe, pois sabe que ainda não pode fazer parte daquele movimento. Ela narra o modo como as mulheres estão vestidas e penteadas. Ao admirar o jeito do penteado das amigas de sua mãe: "franja trançada, com moedas de ouro na ponta" ou, ainda, as tranças, sutilmente elaboradas de sua tia Aida, ela comunica ao público: "Dizem que isso é para mostrar a nós, crianças, como nossos tataravós, que nunca conhecemos, penteavam o cabelo" (DIOUF, 2005, p. 9).

Essa situação comunicada por Bintou é plural e ressignifica o olhar sobre os povos africanos. Ao mostrar de dentro o modo como as práticas do seu cotidiano particular perpetuam valores e conhecimentos, a narradora-protagonista evidencia as tradições culturais de trançar os cabelos como traço da ancestralidade. Ou seja, um modo de aprendizagem pela tradição oral e preservação da memória cultural, pelo coletivo de mulheres. E, como afirma Leite (2012, p. 240): “a oralidade é, assim, o elemento fundamental que surge, no romance como valor dos testemunhos do nosso narrador, "historiador" encartado, que faz uso do ouvido e da palavra".

Após observar a reunião de mulheres, Bintou passeia pela sua vila e alcança a praia, onde vê dois garotos se afogando. Ela consegue pedir ajuda e salvar os meninos. O seu ato de coragem é aplaudido por todos. A mãe lhe interroga: "Diga-nos o que você mais deseja?" A irmã de Bintou, Fatou, intercede dizendo: "Ela sonha com tranças". A mãe então conclui, com uma profecia: "Então você terá suas tranças" (DIOUF, 2005, p. 26).

Essa promessa da mãe é cumprida na narrativa através do sonho que Bintou tem à noite. Nesse sonho, aparece uma moça vestida como Bintou costuma se vestir, com uma diferença: ela usa belas tranças com miçangas coloridas na ponta. Esse interessante recurso da narrativa em tratar as temporalidades: presente e futuro, dialoga com a fala de Leite (2012, p. 172) ao tratar dos contos ou provérbios africanos. Para a autora, os contos são "entremeados por provérbios, sentenças e fragmentos proverbiais, que assinalam uma sabedoria assimilada e retransmitida pela boca das personagens narradoras".

O tom proverbial está presente na narrativa, através da valorização das temporalidades expressas nas falas das personagens, ao proporem que haverá um tempo para cumprimento do desejo de Bintou. A temporalidade projetada no sonho de Bintou pode representar a importância dos ritos de passagem como constituição da identidade negra. 
Quando Bintou desperta do sonho, pela manhã, sua avó a convida para um momento especial de aprendizagem. Nesse espaço, a avó começa a transmitir-lhe palavras de incentivo. Numa proposta de construção de uma imagem positiva, sua avó afirma que "seu cabelo será tão especial quanto você". Enquanto a menina espera que se cumpra a promessa e o sonho de receber o prêmio das tranças, ela é surpreendida pelos "dedos rápidos e rasteiros" de sua avó na elaboração de um penteado (DIOUF, 2005, p. 31).

Habilmente, sua avó, agora "fada", num toque de mágica, faz a transformação no cabelo de Bintou. A vó pede: "Abra os olhos, querida Bintou". Diante do espelho a menina constata: "É quando vejo pássaros amarelos e azuis em meu cabelo" (DIOUF, 2005, p. 31). A promessa se cumpre, tal como no sonho, os pássaros povoam os birotes da cabeça de Bintou. A avó, com sua sabedoria, encontra um meio de alegrar Bintou sem desrespeitar as regras da comunidade.

A presença dos pássaros como adorno nos cabelos de Bintou, fruto da intervenção da avó-fada, pode ser lida também como a invocação da ancestralidade, como um guia de proteção, um amuleto de sorte. Esses elementos, pássaros e cabelos, são discursos proverbiais ricos em aprendizagem. E podem insinuar a presentificação das memórias orais africanas.

Avó e neta costuram um momento de aprendizagem e de magia. Avó e neta constroem elos através de discursos repletos de significação. Como representante maior da comunidade, a avó indica caminhos para que a neta aprenda a se ver como pessoa pertencente e especial. Após o grande momento de aprendizagem de sua africanidade, Bintou mira-se ao espelho e discursa:

\footnotetext{
Foi-se a menina sem graça com quatro birotes na cabeça. No espelho, aparece uma garota com um lindo cabelo olhando para mim. Eu sou Bintou. Meu cabelo é negro e brilhante. Meu cabelo é macio e bonito. Eu sou a menina dos pássaros no cabelo. O sol me segue, e estou muito feliz (DIOUF, 2005, p. 32).
}

O espelho social no qual Bintou mira-se reflete a imagem de uma personagem repleta de discursos significativos, que apresenta um meio de conhecer os costumes africanos para a compreensão e reflexão da construção da identidade afro-brasileira. E isso ocorre de maneiras diversas, inclusive pelo resgate histórico das características étnicas e a contextualização das diversidades culturais. Dessa forma, o texto rompe com processo de exotização da pessoa negra.

Pelo olhar de Bintou é possível desconstruir o imaginário negativo que envolve o povo da diáspora africana. Entre outros, avó e neta não são apenas personagens, são discursos que constroem pontes entre passado e presente, a fim de ressignificar o futuro, 
através da marcação simbólica da tessitura dos cabelos. Essa contestação, tanto em Bintou quanto em Betina, representa o rompimento com a tríade: rejeição, negação e invisibilidade.

Entre as narrativas $O$ Espelho Dourado, Betina e As tranças de Bintou percebese elementos dos contos de fadas clássicos e contemporâneos: o real e o imaginário caminham juntos. Na narrativa Histórias da Preta, por sua vez, é possível observar a necessidade de formação do leitor, mais diretamente. Se Bintou conduz o olhar para dentro de uma determinada comunidade africana, Preta reapresenta o continente africano ao leitor.

Histórias da Preta é uma narrativa cuja marca é a presença de vários espelhos sociais. São eles os elementos que poderão auxiliar na desconstrução do imaginário que a sociedade brasileira mantém sobre o continente africano. A esse respeito, Gomes (2006, p. 143) discute que a imagem que o "negro brasileiro" observa, é de uma África que se afunda em guerras e conflitos. A empreitada apontada por Gomes (2006) é a de reversão dessa imagem. É a de recuperar valores artísticos e culturais para que a identidade do negro brasileiro seja construída sem "a marca da coisificação".

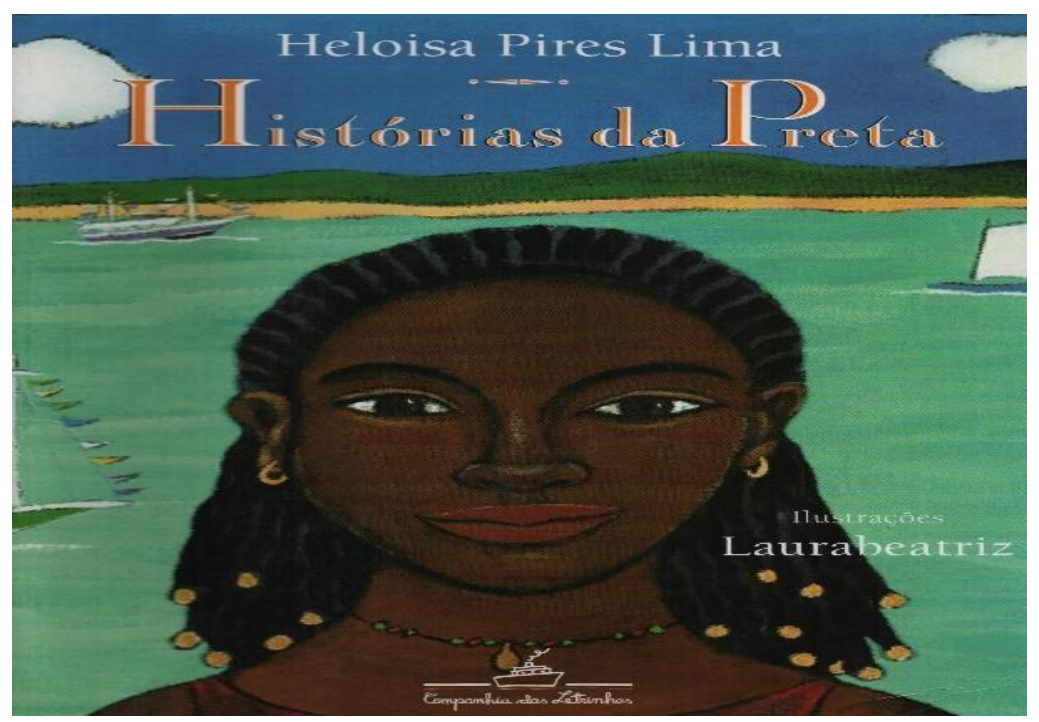

Figura 14: A menina Preta e suas tranças. Em Histórias da Preta, 1998, capa.

De modo muito especial, a narradora-protagonista já se autoafirma: "Eu sou a Preta”. Esta atitude da protagonista ancora toda a tradição e a importância de se assumir como pessoa negra. Essa afirmativa é a proposta do eu enunciador em dar visibilidade e, de algum modo, a confrontação necessária para a contestação de estereótipos à brasileira. O discurso da coisificação é facilmente desconstruído na narração de Histórias da Preta. 
Quando a protagonista-narradora assume sua identidade pelo "Eu sou", abrem-se subsídios para a discussão sobre a construção da subjetividade e da identidade. Ao discutir com sua avó a questão da etnia e da cor das pessoas, a narradora-protagonista inicia uma trajetória para descobrir "quantas sementes carrega dentro de si” (LIMA, 2002, p. 13).

Essa postura de autorreflexão de Preta relaciona-se com os estudos de Hall (2005), ao propor que a construção da identidade dá-se-á ao longo de um tempo, nas vivências e experiências. As inquietações de Preta se apresentam em discursos carregados de significações que trazem a memória coletiva dos povos africanos. São as "sementes" que ela relaciona às origens africanas.

Assim, a personagem Preta nos apresenta um sujeito pós-moderno, descentrado e híbrido. A protagonista-narradora Preta é uma personagem que, não apenas rompe com o emudecimento das personagens negras, mas, como lembra Rosemberg (1985, p. 85), devolve à pessoa negra seu lado humano e desassociado à sujeira, à tragédia, à maldade.

Preta é uma personagem que representa a "minoria" emudecida que é a criançamenina-negra, por subverter pelo poder da fala, pelo "eu sou", bem como ao apresentar as Áfricas para o público leitor. Sua voz está carregada de discursos políticos. De seu lugar de fala, ela fala muito. Ela redimensiona o olhar do leitor, quer seja criança ou adulto, como mostra a citação: "Cresci uma menina igual a todas as meninas e diferente de todas as outras. Desse jeito sou eu com minha história, nesta história com todos os tamanhos que couberem neste livro" (LIMA, 2007, p. 5).

As falas de Preta ao longo da diegese demonstram um olhar engajado nas questões étnicas e de gênero. Parafraseando Bhabha (2010, p.19), a consciência das posições de sujeito em Histórias da Preta resulta da ressignificação das categorias de gênero, de etnia, de classe e de faixa etária. Surge, então, uma protagonista que difere de Betina ou de Bintou por assumir uma responsabilidade maior: a de ressignificação do olhar do povo negro, bem como do não-negro, brasileiro para as diversas Áfricas.

A plataforma política, por assim dizer, de Preta vai desde a reflexão sobre o "que é ser uma pessoa negra", onde propõe uma discussão sobre as "etiquetas" que determinam o que a pessoa é. Nesse sentido, ela reflete: "Dizem que sou afro". A partir desta sentença, faz as associações sobre sua possível origem: “para nascer é preciso duas origens”. Depois de realizar uma matemática de sua árvore genealógica, Preta constata: "Todo mundo nasce carregado de origens". E explica:

Mas a origem africana está na cara. E também no coração. Ser africano é diferente de ser italiano ou francês. A África não é um país, mas um continente com muitos países, e cada qual com etnias diferentes. Então, em quantos 
lugares da África eu tenho origens? E, mais: se todo o mundo voltar no tempo e no espaço de sua história, vai descobrir que onde o bicho homem virou gente foi na África. Foi no continente africano que encontraram o fóssil humano considerado até agora o mais antigo do planeta, com mais de 40 mil anos de idade. É dessa gente antiga que todo mundo descende (LIMA, 2007, p. 9).

Essa passagem está rica de representação, de significações. A protagonistanarradora inquieta com suas colocações. Dificilmente o leitor desse texto deixará de refletir sobre a questão do mito da democracia racial no Brasil. Dialogando com Moscovici (2000), através das falas, gestos e outros eventos cotidianos, as representações sociais são tangíveis ao estabelecerem um espaço de comunicações possíveis, dos valores ou ideias presentes pelas experiências partilhadas pelos grupos.

Ao propor a discussão da construção da identidade negra, Preta afirma que "ainda que todo o mundo seja africano na origem, nem todo o mundo é visivelmente negro hoje em dia. É um quebra-cabeça, essa história”. (LIMA, 2007, p. 9). Então, para compor as peças desse quebra-cabeças, a protagonista-narradora manipula, peça a peça, o jogo da construção da identidade. E cada peça é transformada em um capítulo do livro.

Assim, as peças do jogo das identidades afro-brasileiras vão ganhado vida nas falas da narradora. Preta dialoga com seu interlocutor e lhe mostra as várias etnias africanas, as memórias orais através do conto sobre a criação do mundo e a força da palavra através dos griots e diélis. Preta destaca a fala de um griot: "Quem estraga sua palavra, estraga a si mesmo" (LIMA, 2007, p. 23).

De pergunta em pergunta, a narradora-protagonista vai conduzindo o leitor e discutindo questões primordiais para a construção da identidade. Assim, perguntas saltam, de capítulo em capítulo. Por exemplo, para a discussão sobre o tráfico de seres humanos, ela questiona: "Mas de qual África as pessoas negras descendem? E eu?" (LIMA, 2007, p. 26). Ou ainda: "Mas uma confusão que costuma acontecer é imaginar que todas as pessoas negras eram escravas" (LIMA, 2007, p. 40).

Entre outras questões capitais, a Preta narra o episódio do Atlântico Negro por um olhar perspicaz e transgressor: "Viver de escravizar pessoas foi uma prática que se prolongou por anos, e até hoje os povos sofrem as consequências dessa história” (LIMA, 2007, p. 36). Outro feito importante da narradora foi mostrar as revoltas e insurgências dos escravos, como, por exemplo, a Revolta da Chibata, liderada por "João Cândido". Esse aspecto na narrativa é relevante para o entendimento da resistência do povo negro, e sua importância na construção de uma identidade negra que confronte a imagem do povo negro servil, tão divulgada. 
Preta se olha no espelho após observar as diferenças entre ela e uma amiga "tão branca quase parecia tranparente". Ela narra:

\begin{abstract}
por causa dessa diferença, um dia me olhei no espelho e vi meu rosto negro, meus lábios vermelhos, minha pintinha preta, meus olhos mais pretos ainda. Olhei para dentro de mim para ver se via minha pele por dentro. Olhei, olhei, até que um dia virei do avesso. E depois desvirei! (LIMA, 2007, p. 46).
\end{abstract}

Nesse jogo de metáforas, a narradora-protagonista propõe a discussão da construção da identidade pela diferença e alteridade. A profundidade do olhar empreendido por Preta, o que pode representar? Ao se olhar no espelho, Preta se reafirma como pessoa negra. A construção não foi simples. Para tal, ela voltou-se para estruturas e caminhos difíceis que são a busca por dentro, a busca do autoconhecimento para se reconhecer. Desse modo, ela se desvirou, pois já havia se encontrado como pessoa negra.

Ela prossegue enumerando situações de racismo que ocorrem no espaço da escola. Então, Preta reflete, novamente: "Como é o ser negro que aprendi na escola?" Ela conclui que personagens negros são ausentes na literatura escolar. Essa postura autorreferencial na narrativa remete, tanto na ficção quanto na realidade, à ausência ou pouca recorrência de representação da pessoa negra na sociedade brasileira.

É no espelho social que Preta vê as questões de discriminação, assimilação e negação da pessoa negra se refletirem. Ela vê surgir imagens negativas tanto nos livros, quanto nas falas das pessoas. Ao estudar o significado da palavra "negro" no dicionário da biblioteca da escola, ela observa que os sinônimos relacionados à palavra "negro" significam ou se associam à ideia do que é ruim, cruel, mal e sujo. Então, ela conclui: "Saí da sala achando que ser negro não era muito bom não" (LIMA, 2007, p. 48).

Essa afirmativa de Preta constitui uma pausa para reflexão, na diegese. Pausa para a narradora discursar e provar que a história não termina aí. Preta prossegue confrontando o leitor e instigando-o a ir mais além. O seu espelho se multiplica. É como entrar na sala de espelhos de Alice e ver outras imagens refletidas. A narradora-protagonista propõe: "É preciso prestar atenção à semântica! Ela é uma prática para justificar a superioridade de uma população sobre a outra, desprezando-a cotidianamente em pequenas fórmulas de associações negativas" (LIMA, 2007, p. 48).

Preta percebe pelo espelho social as várias nuances por onde o racismo se esconde. E ela começou a pensar nos opostos que se "equilibram" sem desconsiderar a diferença, mas afirmando-a. A narradora-protagonista reflete sobre a importância do cumprimento dos direitos na história das pessoas negras, enquanto grupo. E, para desconstruir mais 
ainda o imaginário de preconceito à brasileira, Preta apresenta, detalhadamente, as religiões de matriz africana como caminho para a aprendizagem do que é ser negro.

E, magistralmente, o eu enunciador propõe a discussão final que ser diferente é um mistério: Ser diferente todo mundo é? Ou todo mundo é igual? Quem são os meus diferentes? Preta questiona-se: "Enfim, iguais e diferentes podem ser diferentes e iguais. A diferença enriquece a vida e a igualdade é um direito de todos. Somos iguais nos direitos da vida" (LIMA, 2007, p. 63).

Essa questão da diferença e da igualdade é paradigmática, assim como a personagem Preta. Penetrar os percursos narrativos propostos pelo eu enunciador é rever os posicionamentos ainda carregados de não pertencimento da pessoa negra. A apropriação dessa personagem paradigmática pelo leitor infantil, o que poderá promover? É possível remover, de negros e não negros brasileiros, a imposição da negação e da renúncia, e promover a recondução e ocupação, de espaços sociais de relevância. Esta narrativa pode contribuir na construção de um grupo étnico-racial, através do olhar para si mesmos, na busca pela compreensão de que a identidade negra é uma construção social, histórica e cultural.

Nas narrativas em estudo, o espelho é o portal onde a autoimagem pode ser manifestada. Espelhos e reflexos, retratos e fotografias mostram o nosso rosto que, de outra forma, desconhecemos. Um rosto que se pode amar ou rejeitar. Ou que pode nem existir. Um rosto que corresponde ou não à imagem mental que fazemos dele (SILVA, 2008, p. 57).

As protagonistas Nyame, Preta, Bintou e Betina não são corpos abjetos, não são vozes silenciadas. Corpo e cabelo são os símbolos dos vários povos africanos que elas portam. Não há como refletir sobre a construção de uma protagonista menina negra sem compreender a linha histórica, a tradição cultural que costura os fios de seus cabelos ao serem trançados. Assim, revelar à criança negra sua afrodescendência é propor-lhe a reflexão de que os espelhos sociais impostos pela sociedade brasileira, não as refletem totalmente.

Repensar, pois, as formas de representação para dar visibilidade à menina negra, não é uma simples tarefa ou motivação de mercado, é uma urgente atitude da qual a literatura infantil contemporânea não pode se esquivar. 
"E a literatura hoje ganhou cara nova"

(LAJOLO, 2001, p. 9)

Considerações finais 
Refletir, pois, sobre a presença da menina negra no campo da literatura infantil implica, entre outras estratégias, posicionar-se. E, no âmbito da literatura infantil, o posicionamento está se voltando para o protagonismo da menina negra e o seu não silenciamento.

Essa postura liga-se ao que estuda Marisa Lajolo (2001). A autora propõe uma intensa discussão sobre a produção cultural e sobre o que é e o que pode vir a ser literatura. Ela adverte que a literatura infantil está longe de ser artesanal. A literatura infantil, segundo a autora, "é uma produção industrial tão sofisticada quanto a indústria de alimentos" (LAJOLO, 2001, p. 9).

Dialogando com Lajolo, Vera Maria Tietzmann Silva (2014) reflete sobre a importante ampliação do mercado editorial brasileiro, que somente perde para ao que é produzido na Inglaterra. No entanto, a produção e editoração das obras literárias, segundo a autora, devem seguir um trilho. Então, ao mesmo tempo que possibilita a maior circulação de livros, o mercado editorial engessa, de algum modo, a produção cultural.

Todavia, pensar a literatura infantil contemporânea como subversão, resistência e reconstrução de caminhos, é também contar com as possibilidades desse "ambíguo e engessado" mercado editorial brasileiro. É observar-lhe as estratégias de circulação de obras que discutem, tanto no nível particular, quanto no público, os espaços dicotômicos de voz e de representação que ressignificam o olhar perante a pessoa negra, na visão de quem está fora: o outro. E, na assunção da pessoa negra sobre si mesma, num processo de desalienação.

A respeito da construção da identidade pela presença da alteridade, é preciso concordar com Fanon (2008), que reflete: “Quero sinceramente levar meu irmão negro ou branco a sacudir energicamente o lamentável uniforme tecido durante séculos de incompreensão" (FANON, 2008, p. 30).

Entretanto, para representar e dar visibilidade à menina negra, a exemplo do que acontece nas obras aqui discutidas, é preciso pensar que a literatura "é um objeto social muito especifico" (LAJOLO, 2001, p. 17). Esta proposta de Lajolo dialoga com a postura da literatura infantil afro-brasileira produzida na contemporaneidade. Ou pelo menos, o que se divulga como objetivo desse específico campo artístico.

Durante toda a pesquisa aqui empreendida ficou clara a relação da literatura infantil como campo artístico, que na pós-modernidade precisa cumprir novos papéis sociais, culturais e históricos. Nessa empreitada de recondução da literatura infantil na vertente afroidentificada, é preciso incluir a importância da autoria feminina negra que 
sacudiu, energicamente, o mercado editorial brasileiro com sua escrevivência. É também preciso valorizar a autoria de narrativas visuais.

Revirando tudo, Zilbermann (2003, p. 220) discute, exaustivamente, a relação adultocêntrica na literatura infantil. Ela também propõe a necessidade de se repensar esta relação e aponta para o deslocamento da criança leitora como meio de subverter a relação adultocêntrica presente na produção do texto infantil. Embora trate de outras funções dentro do campo de estudo da literatura que é a recepção, a criança leitora conversa com o protagonismo que se pretende dar pela representação da menina na literatura infantil, uma vez que reverter todos os processos de discriminação, inclui pensar a criança negra, em todos os seus papéis.

É possível que esta postura leitora se insira na questão de mercado como proposta de visibilidade pelo letramento. Letramento literário para Rildo Cosson (2014) é o aprendizado crítico da leitura literária, que não se faz sem o encontro pessoal com o texto enquanto princípio de toda a experiência estética (COSSON, 2014, p. 120). Então, pensar a menina negra como sujeito é observá-la como pessoa atuante em sua sociedade e que pode vivenciar tal experiência estética. O autor propõe a construção de um sujeito da escrita como meio de "reconstruir-se pela força da palavra" $(2014$, p. 16).

Em verdade, esta referência demonstra a multiplicidade da literatura infantil enquanto campo de arte. Voltar a Fanon é imprescindível. É ele quem questiona "O que quer o homem negro"? Esta inquisição de Fanon tem vários ecos. Ecoa, por exemplo, em Bhabha que a aprofunda e propõe que "a questão da identificação nunca é a afirmação de uma identidade pré-dada, nunca uma profecia autocumpridora - é sempre a produção de uma imagem de identidade e a transformação do sujeito ao assumir aquela imagem" (BHABHA, 2010, p. 77).

Desta forma, ao longo do texto em estudo foi possível perceber que a literatura infantil tem essa força e que pode contribuir para o rompimento dos estereótipos voltados à menina negra, como meio de repensar o presente tendo em vista a construção do futuro. Como assevera Jesualdo (1993, p. 19), é preciso existir uma literatura infantil que interesse à idade infantil. Então, para representar a criança negra, a literatura infantil precisa dialogar com seu anseio de ser e estar no mundo, de pertencer e ser valorizada.

As protagonistas levantadas no estudo das narrativas rompem com os estereótipos que a sociedade comumente atribui à menina negra. Ter voz, então, é primordial para subverter a ordem onde os estereótipos constituem o controle social. Dar voz à menina negra contribui para a diminuição da negação e invisibilidade na literatura em geral. Dar 
voz e corpo humano à menina negra pode reconduzir o olhar para os aspetos culturais dos quais ela é herdeira.

Compreender o espaço social no qual a menina negra transita na literatura infantil analisada amplia a visão, por dentro, de seu pertencimento cultural, do elo de memória ancestral representada na relação entre o passado e o presente, entre a figura da avó e sua interação com a neta. Observar a menina negra como corpo pertencente e humanizado redimensiona o posicionamento quanto à sua importância como sujeito social.

Se a literatura infantil, como reflete Jaqueline Held (1977), é a passagem do mundo da leitura para a leitura de mundo, cabe aqui a reflexão de que ela seja o filtro por onde passa a sociedade. Para tanto, ela não se desvincula dos papéis sociais ligados à questão de sua função como moralizadora ou educadora. Contudo, pela trajetória de sua gênese aos dias de hoje, certamente precisa reivindicar para si a característica de obra de arte e se assumir como tal.

Assim, a literatura infantil se torna o espaço legitimo para a representação da menina negra e o espelho pelo qual ela poderá se mirar. Uma maneira de intervir no mundo. Afinal, parafraseando Lajolo (2001), enquanto arte, a literatura está de cara e corpo novos. Enquanto espaço de construção social, a literatura infantil contemporânea tem cara nova: a menina negra. 


\section{Referências}

ARIÈS, Philippe. História social da criança e da família. 2 ed. Rio de Janeiro: LTC, 2012.

ARNHEIM, Rudolf. Arte e percepção visual: uma psicologia da visão: nova versão. Trad. Ivonne Terezinha de Faria. São Paulo: Cengage Learning, 2008.

ARROYO, Leonardo. Literatura infantil brasileira. 3.ed. São Paulo: Editora UNESP, 2010.

AUERBACH, Erich. A novela no início do renascimento: Itália e França. São Paulo: Cosac Naify, 2013.

BACHELARD, Gaston. A água e os sonhos. Trad. Antônio de Pádua Danesi. São Paulo: Martins Fontes, 1998.

BAKTHIN, Mikhail. Estética da criação verbal. Trad. Paulo Bezerra. 6 ed. São Paulo: Martins Fontes, 2011.

BARROS, Manoel de. Poesia completa. São Paulo: Leya, 2013.

BARTHES, Roland. O mito, hoje. In: Mitologias. Trad. Rita Buongermino e Pedro de Souza. 4. ed. Rio de Janeiro, Bertrand Brasil S, A. , 2009.

BEAUVOIR, Simone de. O segundo sexo: fatos e mitos. Trad. Sérgio Milliet. Rio de Janeiro: Nova Fronteira, 1980.

BATT, Tanya Robyn. O tecido da serpente Pembe Mirui. In: Tecidos dos contos maravilhosos: contos de lugares distantes. 1. ed. São Paulo: UMF Martins Fontes, 2010.

BETTELHEIM, Bruno. A psicanálise dos contos de fadas. Trad. Arlene Caetano. Rio de Janeiro: Paz e Terra, 1980.

BOURDIEU, Pierre. As regras da arte: gênese e estrutura do campo literário. Trad. Maria Lúcia Machado. São Paulo: Companhia das Letras, 2002.

BUTLER, Judith. Fundamentos contingentes. Cadernos Pagu 11, 1998.

CADEMARTORI, Lígia. O que é literatura infantil? 2. ed. São Paulo: Brasiliense. 1990. (Coleção Pequenos Passos).

CARROLL, Lewis. Alice no país do espelho. Trad. Rosaura Eichenberg. Porto Alegre: L \& PM Pocket, 2004.

CASCUDO, Luís Fernando da Câmara. Literatura oral no Brasil. 2. ed. São Paulo: Global, 2006.

CHARTIER. Roger. Leituras e leitores na França do Antigo Regime. Trad. Álvaro Lorencini. São Paulo: Editora UNESP, 2004. 
Origens culturais da revolução francesa. São Paulo: UNESP, 2009.

A aventura do livro do leitor ao navegador. São Paulo: UNESP, 2009.

CHAVES, L. G. Mendes. Minorias e seu estudo no Brasil. Revista de Estudos Sociais, Fortaleza, 1970, v. 1, n. 1, p. 149- VRI: www.repositorio.ufc.br/handle/ruifc/4487.

CERTEAU, Michel de. A invenção do cotidiano: artes de fazer. 21. ed. Petrópolis: Vozes, 2014.

CIRLOT, Juan-Eduardo. Dicionário de Símbolos. Trad. Rubens Eduardo Ferreira Frias. São Paulo: Moraes, 1980.

CHIRINOS, Lúcia Harumi Borba. Arte e oralidade entre os ashanti: classificação e interpretação dos pesos de ouro. Texto para comunicação no XI SIICUSP, setembro de 2003. Revisto e adaptado em dezembro de 2004. www.arteafricana.usp.br/codigos/artigos/001/arte_oralidade_ashanti.html.

COELHO, Nelly Novaes. Panorama histórico da literatura infantil/juvenil: Das origens indo-européias ao Brasil contemporâneo. Barueri: Manole, 2010, 5 ed.

A literatura infantil. 2. ed.São Paulo: Global, 1982.

Literatura: arte, conhecimento e vida. São Paulo: Peirópolis, 2000.

COLOMER, Teresa. A formação do leitor literário. Trad. Laura Sandroni. São Paulo: Global, 2003.

COSSON, Rildo. Letramento literário: teoria e prática. 2. ed. São Paulo: Contexto, 2014.

DACASTAGNÈ, Regina. Representações restritas: a mulher no romance brasileiro contemporâneo. In: __ Deslocamentos de gênero na narrativa brasileira contemporânea.

DALCASTAGNÈ, Regina, LEAL, Virgínia Maria Vasconcelos. (Org). São Paulo: Horizonte, 2010.

DIOUF, Sylviane A. As tranças de Bintou. Trad. Charles Cosac. Ilustrações de Shane W. Ewans. 2. ed. São Paulo: Cosac Naify, 2005.

DUARTE, Eduardo de Assis. Literatura afro-brasileira: 100 autores do século XVIII ao XXI. Rio de Janeiro: Pallas, 2014.

2014.

Literatura afro-brasileira: abordagens na sala de aula. Rio de Janeiro: Pallas,

FANON, Fanz. Pele negra, máscaras brancas. Trad. Renato da Silveira. Salvador: EDUFBA, 2008.

FERREIRA, Aurélio Buarque de Holanda. Miniaurélio: o dicionário da língua portuguesa. 6. ed. Curitiba: Positivo, 2004.

FISCHER, Steven Roger. História da leitura. São Paulo: Unesp, 2006. 
FITIPALDI, Ciça. O que é uma imagem narrativa? In: O que é qualidade em ilustração no livro infanto juvenil: com a palavra o ilustrador, org. Ieda Oliveira. São Paulo: Difusão Cultural do Livro, 2008.

GILBERT, Sandra; GUBAR, Susan (1979). De infecção na sentença: a escritora e a sociedade de autoria. In: . A louca no sótão: a escritora e a imaginação literária do século XIX. 2. ed. 2000.

GOMES, Nilma Lino. Betina. Ilustrações de Denise Nascimento. Belo Horizonte: Mazza Edições, 2009.

- Sem perder a raiz: corpo e cabelo como símbolos da identidade negra. 2. ed. Belo Horizonte: Autêntica, 2008.

. A mulher negra que vi de perto. 2. ed. Belo Horizonte: Mazza edições, 1995.

. (Org) Um olhar além das fronteiras: educação e relações sociais. Belo Horizonte: Autêntica, 2007.

HALL, Stuart. A Identidade Cultural na Pós-Modernidade. 11. ed. RJ: DPeA Editora, 2006.

. Identidade cultural e diáspora. Revista do Patrimônio Histórico e Artístico Nacional, n. 24, 1996, p. 68-75.

Da Diáspora: Identidades e mediações culturais. Trad. Adelaide La Guardia Resende. Belo Horizonte: Editora UFMG; Brasília: Representação da UNESCO no Brasil, 2003.

HAUSER, Arnold. História social da arte e da literatura. Trad. Álvaro Cabral. São Paulo: Martins Fontes, 2003.

HELD, Jaqueline. O imaginário no poder: as crianças e a literatura fantástica. São Paulo: Summus, 1980.

IBÃNEZ, Célia Ruiz. Folclore brasileiro infantil. São Paulo: Girassol, 2006.

JESUALDO. A literatura infantil. Trad. James Amado. São Paulo: Cultrix, 1988.

JOLY, Martine. Introdução à análise da imagem. 6. ed. Campinas: Papirus, 2003.

LAJOLO, Marisa. Literatura: leitores e leitura. São Paulo: Moderna, 2001.

LEITE, Ana Mafalda. Oralidades e escritas pós-coloniais: estudos sobre literaturas africanas. Rio de Janeiro: Eduerj, 2012.

LIMA, Luís Costa. Mímesis: Desafio ao pensamento. Rio de Janeiro: Civilização Brasileira, 2000.

LIMA, Tânia; NASCIMENTO, Izabel; OLIVEIRA, Andrey. Griots- culturas africanas: linguagens, memória, imaginário. 1. ed. Natal: Lucgraf, 2009. 
LOPES, Ney. Dicionário Literário Afro-Brasileiro. Rio de Janeiro: Pallas, 2011.

Enciclopédia Brasileira da Diáspora Africana. São Paulo: Selo Negro, 2004.

MAAS, Wilma Patrícia Marzari Dinardo. O romance de formação (Bildungsroman) no Brasil. Modos de apropriação. Caminhos do Romance (2005).

MACHADO, Ana Maria. Silenciosa algazarra: reflexões sobre livros e práticas de leitura. São Paulo: Companhia das Letras, 2011.

MEC. Orientações e Ações para a Educação das Relações Étnico-Raciais. Brasília:SECAD, 2010.

. Olhares Feministas/Hildete Pereira de Mello. In: Fragmentos de corpo e gênero entre meninos e meninas de rua. Simone Miziara Frangella. Brasília:UNESCO, 2009.

Educação anti-racista: caminhos abertos pela Lei Federal nº10.639/03. In:

Discriminação Racial e Pluralismo nas escolas públicas da cidade de São Paulo. Eliane Cavalleiro.Brasília:UNESCO, 2005.

. Educação anti-racista: caminhos abertos pela Lei Federal nº10.639/03. In: Representação da Personagem Feminina Negra na Literatura Infanto-Juvenil Brasileira. Andréia Lisboa de Sousa. .Brasília:UNESCO, 2005.

Educação anti-racista: caminhos abertos pela Lei Federal nº10.639/03. In: Alguns termos e conceitos presentes no debate sobre relações raciais no Brasil: uma breve discussão. Nilma Lino Gomes. Brasília:UNESCO, 2005, p.39 a 62.

. História Geral da África. Vol I e II. 2 ed. Brasilia: UNESCO, 2010.

MIGNOLO, Walter D. Histórias locais/ projetos globais: colonialidade, saberes subalternos e pensamento liminar. Trad. Solange Ribeiro de Oliveira. Belo Horizonte: Editora UFMG, 2003.

MOISÉS, Massaud. Dicionário de termos literários. 12ª ed. São Paulo: Cultrix, 2013.

MOSCOVICI, Serge. Representações sociais: investigações em psicologia social. 8. ed. Petrópolis, RJ: VOZES, 2011.

MUNANGA, Kabengele. Negritude: usos e sentidos. Belo Horizonte: Autêntica Editora, 2008.

Superando o racismo na escola. 2 ed. Brasília: UNESCO, 2005.

NUNES, Marcelo Costa e ALVES, Rafael. Oyé Orixá: umbanda e síntese dos princípios do branco, do vermelho e do negro. Brasília: Casas das Musas, 2009.

PIRES, Heloísa Lima. O Espelho Dourado. Ilustrações de Taísa Borges. São Paulo: Peirópolis, 2003. 
Histórias da Preta. Ilustrações de Laura Beatriz. 2. ed. São Paulo: Companhia das Letrinhas, 2005.

PITKIN, Hanna Fenichel. Representação: palavras, instituições e ideias. Lua Nova, n. 67, p. 15-47, 2006.

PRIORE, Mary Del. Histórias das crianças no Brasil. 7. ed. São Paulo: Contexto, 2013.

RICOEUR, Paul. A memória, a história, o esquecimento. São Paulo: Unicamp, 2007.

ROSEMBERG, Fúlvia. Literatura infantil e ideologia. São Paulo: Global, 1985.

SANTOS, Sônia Beatriz dos. Feminismo negro diaspórico. GÊNERO. Niterói, v.8, n. 1, p. 11-26, $2^{\circ}$ sem. 2007.

SHOHAT, Ella ; STAM, Robert. Crítica da imagem eurocêntrica: multiculturalismo e representação. Trad. Marcos Soares. São Paulo: Cosac Naify, 2006.

SILVA, Tomaz Tadeu da (Org). Identidade e diferença: a perspectiva dos estudos culturais. Stuart Hall, Kathryn Woodward. 14. ed. Petrópolis: Vozes, 2014.

SILVA, Vera Maria Tietzmann. Literatura infantil brasileira: um guia para professores e promotores de leitura. 2. ed.Goiânia: Cânone Editorial, 2009.

DENÓFRIO, Darcy França; TURCHI. Maria Zaira. Antologia do conto goiano. Volume 1: Dos anos dez aos anos sessenta. 3. ed. Goiânia: UFG, 2013. Texto Nego rei, de Ada Curado, p. 211-216.

SMITH, Ray. Manual prático do artista. Trad. Luiz Carvalho e José Francisco Vidigal. São Paulo: Ambientes e Costumes, 2008.

SCHWANTES, Cíntia. Narrativas de formação contemporânea: uma questão de gênero. In: Deslocamentos de gênero na narrativa brasileira contemporânea. DALCASTAGNÈ, Regina e LEAL, Virgínia Maria Vasconcelos (org). São Paulo: Horizonte, 2010.

SHOWALTER, Elaine. A crítica feminista no território selvagem. In: HOLLANDA, Heloísa Buarque. Tendências e impasses. Rio de Janeiro: Rocco, 1994.

SPIVAK, Gayatri Chakravorty. Pode o subalterno falar? Trad. Sandra Regina Goulart Almeida, Marcos Pereira Feitosa. Belo Horizonte: Editora UFMG, 2010.

STEARNS, Peter N. A Infância. Trad. Mirna Pinsky. São Paulo: Contexto, 2006.

TELLES, Norma. Autoria. In: . Palavras da Crítica: tendências e conceitos dentro da crítica. Org. José Luís Jobim. Rio de Janeiro: Imago, 1992. p. 45-63.

Fios comuns em novos percursos e territórios. In: Deslocamentos de gênero na narrativa brasileira contemporânea. DALCASTAGNÈ, Regina e LEAL, Virgínia Maria Vasconcelos (org). São Paulo: Horizonte, 2010. p.188. 
WOOLF, Virgínia. Um teto todo seu. Trad. Vera Ribeiro. São Paulo: Nova Fronteira 1994.

YOUNG, Iris Marion. "Representação política, identidade e minorias." Lua Nova, n. 67. p. 139-190, 2006.

ZILBERMAN, Regina. A literatura infantil na escola. São Paulo: Global, 2007. 
Anexo 
O menino que carregava água na peneira

(Manuel de Barros, 2003, p. 453).

Tenho um livro sobre águas e meninos.

Gostei muito de um menino que carregava água na peneira.

A mãe disse que carregar água na peneira

Era o mesmo que roubar um vento e sair correndo com ele para mostrar aos irmãos.

A mãe disse que era o mesmo que catar espinhos na água $\mathrm{O}$ mesmo que criar peixes no bolso.

O menino era ligado em despropósitos.

Quis montar os alicerces de uma casa sobre orvalhos.

A mãe reparou que o menino gostava mais do vazio do que do cheio.

Falava que os vazios são maiores e até infinitos.

Com o tempo aquele menino que era cismado e esquisito

Porque gostava de carregar água na peneira

Com o tempo descobriu que escrever seria o mesmo que carregar água na peneira.

No escrever o menino viu que era capaz de ser noviça, monge ou mendigo ao mesmo tempo.

O menino aprendeu a usar as palavras.

Viu que podia fazer peraltagens com as palavras.

E começou a fazer peraltagens.

Foi capaz de interromper o voo de um pássaro botando ponto no final da frase.

Foi capaz de modificar a tarde botando uma chuva nela.

O menino fazia prodígios.

Até fez uma pedra dar flor!

A mãe repara o menino com ternura.

A mãe falou: meu filho, você vai ser poeta.

Você vai carregar água na peneira a vida toda.

Você vai encher os vazios com as suas peraltagens.

E algumas pessoas vão te amar por seus despropósitos. 